Historic, archived document

Do not assume content reflects current scientific knowledge, policies, or practices. 


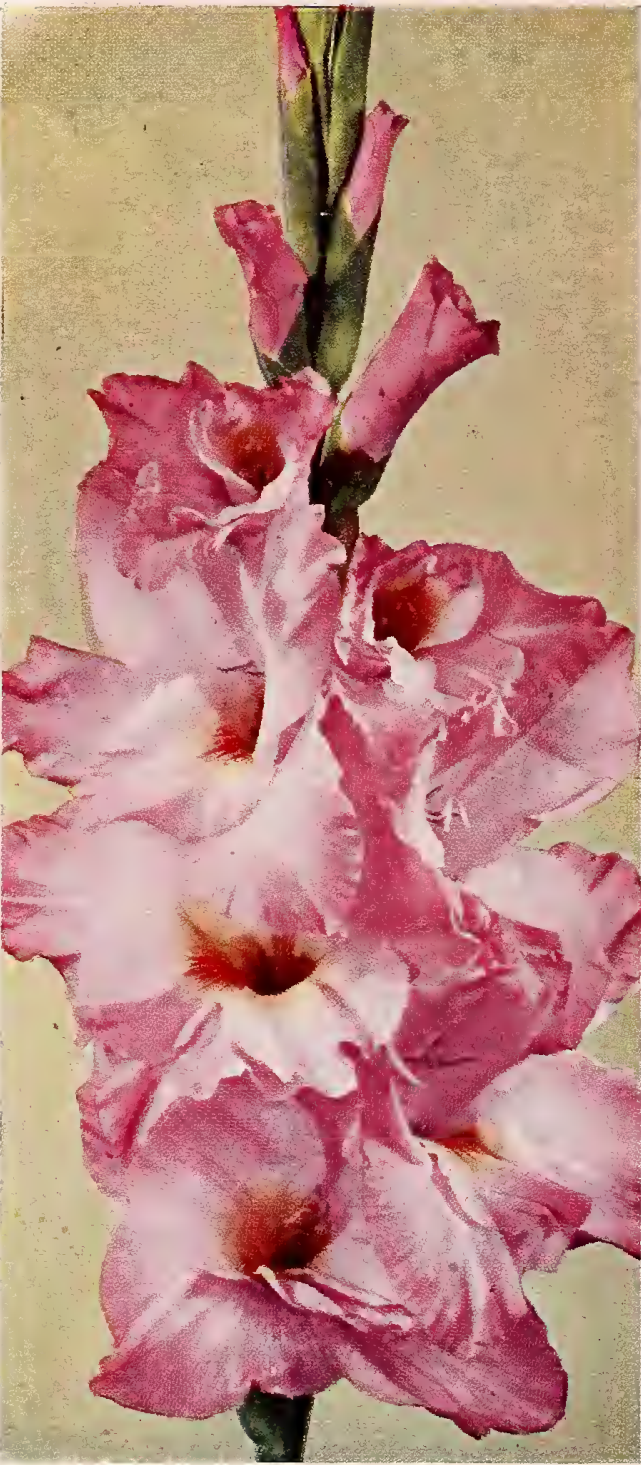

ELIZABETH THE QUEEN

Just before planting, the corms should be dipped for 15 minutes in a solution of of Ceresan M (1 ounce to 3 gallons of water). After the plants are 6 inches tall, spray them at 2-week intervals with Isotox Garden Spray or wettable DDT to prevent damage from thrips.

All are No. 1 grade $\left(1 \frac{1}{2}\right.$ to 2 -inch diameter), clean corms, well grown and free from pests and diseases.

\section{Six Garden Beauties GLAD COLLECTION No. 8703}

5 corms each of Aureole, Elizabeth the Queen, Florence Nightingale, Johan Von Konynenburg, Miss Wisconsin, and Tivoli.

\section{CORMS IN ALL (\$2.84 valuz) ONLY $\$ 2.35$}

If by mail, include $25 c$ additional for packing and postage.

With mail orders send additional money for packing and postage. $25 \mathrm{c}$ for a total of 15 to 49 corms, $45 \mathrm{c}$ for a total of 50 to 100 corms.

\section{WHITE AND CREAM}

8731 Leading Lady. (90 days.) Most popular cream sport of Picardy. 5 for $42 \mathrm{c}$; 10 for $75 c$; 50 or more, 6c each.

8727 Florence Nightingale. (88

days.) A new and beautiful white with a shade of deep cream in the throat. 5 for $58 \mathrm{c}$; 10 for $\$ 1.10$; 50 or more, $9 \mathrm{c}$ each.

8718 Salman's Glory. Very attractive, long spikes of creamy white blooms each with a showy red blotch in the throat. 5 for $42 \mathrm{c}$; 10 for $75 c ; 50$ or more, $6 c$ each.

\section{YELLOW}

8739 Spotlight. (80 days.) Smooth deep yellow with a feathered scarlet throat. 5 for $42 \mathrm{c} ; 10$ for $75 \mathrm{c}$; 50 or more, $6 \mathrm{c}$ each.

8740 Aureole. A favorite among the deep yellows and one of the most heavily ruffled Glads. 5 for $58 \mathrm{c}$; 10 for $\$ 1.10$; 50 or more, $9 \mathrm{c}$ each.

\section{BUFF}

8737 Sunspot. (80 days.) The leader in its class. Light apricotbuff with a rose spot in the throat. 5 for $42 \mathrm{c}$; 10 for $75 \mathrm{c}$; 50 or more, $6 \mathrm{c}$ each.

\section{SALMON-PINK}

8748 Picardy. (90 days.) Clear, soft salmon-apricot. Extremely popular. 5 for $42 \mathrm{c} ; 10$ for $75 \mathrm{c} \cdot 50$ or more, $6 \mathrm{c}$ each. 8750 Spic and Span. (80 days.) New ruffled deep pink with a flush of salmon. 5 for $42 \mathrm{c} ; 10$ for $75 \mathrm{c} ; 50$ or more, $6 \mathrm{c}$ each.

\section{PINK}

8757 Panciora. (85 days.) Clear geranium-pink with red feathering on the lower petal. Not as large as Picardy but preferred by many. 5 for $42 \mathrm{c} ; 10$ for $75 \mathrm{c} ; 50$ or more, $6 \mathrm{c}$ each.

8759 Tivoli. Lovely clear pink. One of the finest new Glads on the market. 5 for $42 \mathrm{c}$; 10 for $75 c ; 50$ or more, $6 c$ each.

ROSE

8708 Burma. (88 days.) Large, heavily ruffled florets of rich deep rose. 5 for 42c; 10 for 75 c 50 or more, $6 \mathrm{ceach}$

8711 Miss Wisconsin. (90 days.) Gorgeous new rose-pink with a high degree of brilliance. 5 for $42 \mathrm{c} ; 10$ for $75 \mathrm{c} ; 50$ or more, $6 \mathrm{c}$ each.

\section{SCARLET AND RED}

8777 Mansoer. (82 days.) A new outstanding black-red variety from Holland. The very large florets are deep blood-red with a velvety blackish brown glow. 5 for $42 \mathrm{c}$; 10 for 75 c; 50 or more, $6 c$ each.

8769 Red Charm. (85 days.) New popular red. A prize-winner at the shows. 5 for $42 \mathrm{c} ; 10$ for $75 \mathrm{c} ; 50$ or more, $6 \mathrm{c}$ each.

8765 Johan Von Konynenburg. A new and lovely scarlet-orange that makes an immediate hit with everyone. 5 for $42 c$; 10 for $75 c$; 50 or more, $6 c$ each.

\section{LAVENDER}

8779 Elizabeth The Queen. (86 days.) Ruffled flowers of clear lavender with darker lines in the throat. 5 for $42 \mathrm{c} ; 10$ for $75 \mathrm{c} ; 50$ or more, $6 \mathrm{c}$ each

\section{PURPLE}

8790 Purple Supreme. (95 days.) Deep purple with lighter edge. 5 for 42 c; 10 for $75 \mathrm{c} ; 50$ or more, $6 \mathrm{c}$ each.

\section{LIGHT VIOLET}

8786 Ravel. (77 days.) Medium blue with a purple throat. 5 for $42 c ; 10$ for $75 c$; 50 or more, 6c each

\section{SMOKY}

8791 Bagdad. Smoky old-rose. 5 for $42 \mathrm{c} ; 10$ for $75 \mathrm{c} ; 50$ or more, $6 \mathrm{c}$ each.

$$
\text { MIXED }
$$

8798 P.-W.'s Superb Mixed. 5 for 33c; 10 for 60 c; 50 or more, $5 c$ each.

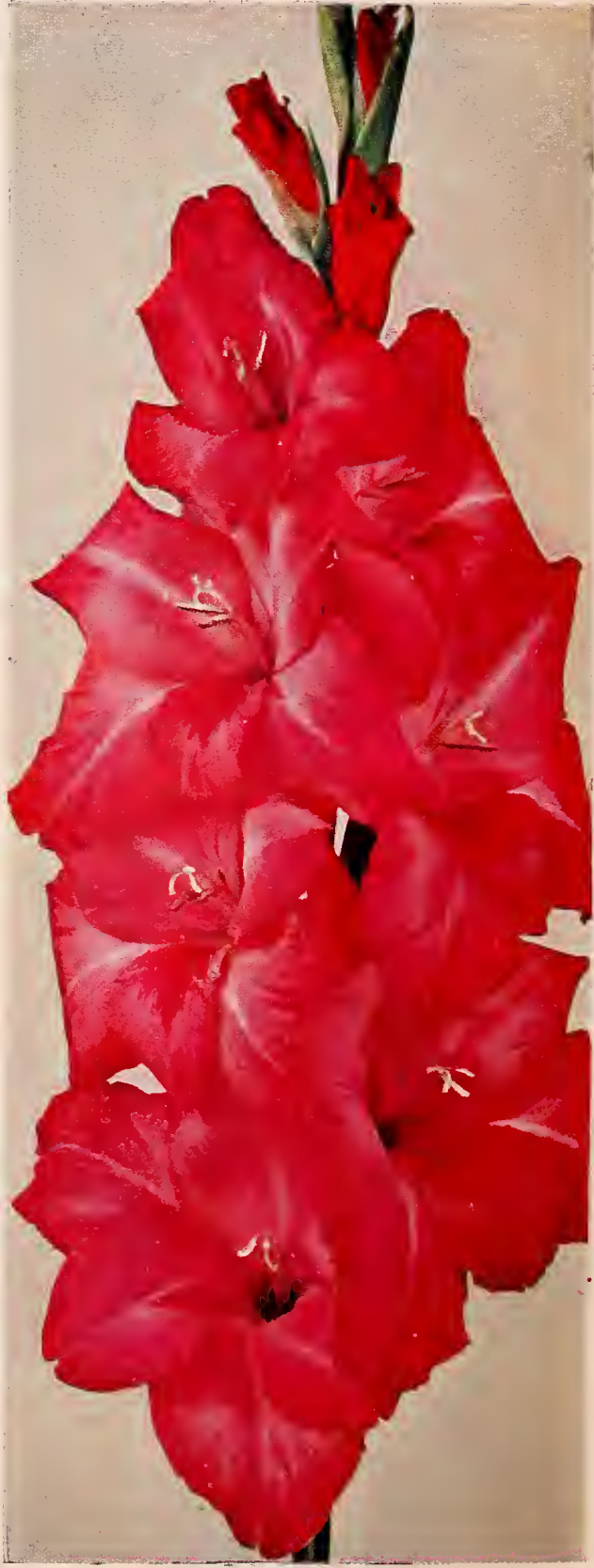

MISS WISCONSIN 
Glarians DAHLIAS

\section{Large Exhibition Class}

8661 Commando. FD. Dark Iavender, almost blue. 50c each 3 for $\$ 1.35$.

8673 D'Arcy Sainsbury. FD. Showy white. $60 \mathrm{c}$ each; 3 for $\$ 1.65$.

8646 Evelyn Chandler. SC. Bright golden apricot with deeper shadings. $75 \mathrm{c}$ each; 3 for $\$ 1.95$.

8619 Fred Springer. ID. Bright red. 50c each; 3 for $\$ 1.35$.

8633 Frieda Gaylord. ID. Lovely deep salmon to shrimp-pink.

$\$ 1.00$ each; 3 for $\$ 2.70$.

8655 Governor Heil. C. Orange-rose with burnt-orange toward the center. $60 \mathrm{c}$ each; 3 for $\$ 1.65$.

8613 Osa Helen. SLC. Best large red cactus. Beautiful American Beauty red. $\$ 1.00$ each; 3 for $\$ 2.70$.

8629 Queen City. FD. Scarlet-pink. $60 \mathrm{c}$ each; 3 for $\$ 1.65$.

\section{Finest Four Dahlias}

COLLECTION No. 8110

One tuber each of Commando, Evelyn Chandler, Osa Helen and Queen City.

$$
\text { (\$2.85 Value) ONLY } \$ 2.35
$$

If by mail, include 20c additional for packing and postage.

\section{Miniature Class}

8669 Baby Royal. SC. Beautiful salmon-

8683 Fairy. ID. Tiny rose-pink tinted lavender.

8672 Ike. FD. Deep ruby-red.

Each of above Miniature Dahlias, 3 of a kind for $\$ 1.10 ; 40 \mathrm{c}$ each

\section{COLLECTION No. 8113}

\section{Dainty Miniatures}

One each of Baby Royal, Fairy and Ike

(\$1.20 Value) only $98 \mathrm{C}$

If by mail, include $18 \mathrm{c}$ additional for packing and postage.

\section{Pompon Class}

8677 Arthur Kerley. Radiant rich rubyred.

8693 Honey. Rich honey-yellow lightly edged red.

8694 Yellow Gem. Rich canary-yellow.

Each of above Pompon Dahlias, 3 of a kind for $\$ 1.10$; $40 \mathrm{c}$ each.

\section{COLLECTION No. 8116}

\section{Pompons for Garden}

One tuber each of Arthur Kerley, Honey and Yellow Gem.

\section{(\$1.20 Value) only 98c}

If by mail, include $18 \mathrm{c}$ additional for packing and postage.

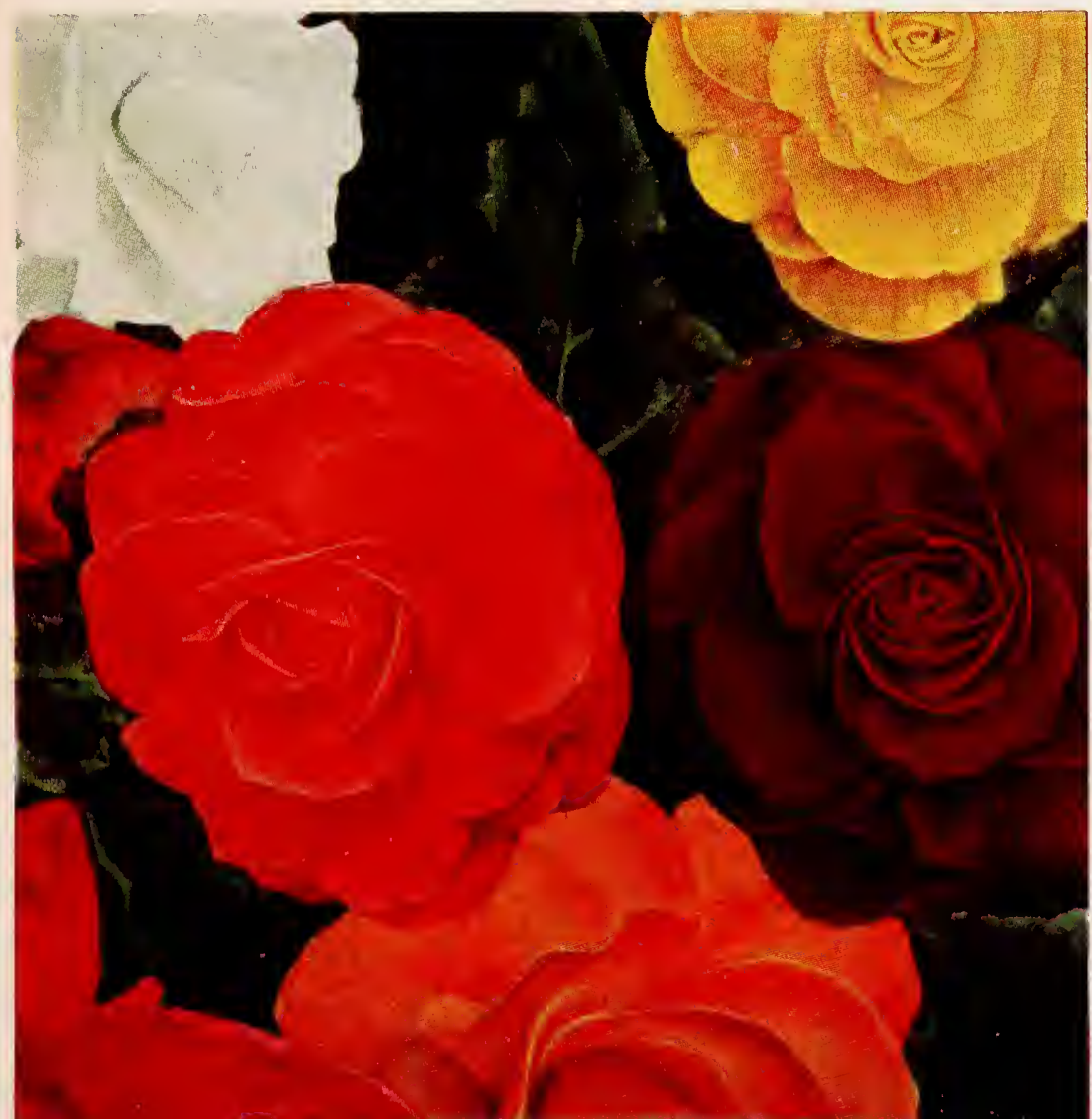

\section{(1)}

TUBEROUS-ROOTED

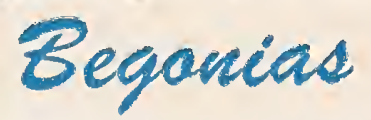

Few plants can equal the Tuberous-rooted Begonias for brilliancy of color and duration and perfection of bloom in the garden. The ideal situation for them is in filtered sunlight where there is plenty of fresh air, protected from strong winds.

\section{Double Giant Camellia- Flowered}

10 to 12 in.

8514 Pink
8510 White

8518 Red

$$
\begin{aligned}
& 8515 \text { Rose } \\
& 8516 \text { Salmon } \\
& 8522 \text { Yellow }
\end{aligned}
$$

\section{Double Carnation-Flowered}

8529 Carnation Mixed. Large blooms resembling carnations, with frilled petals and serrated edges. Desirable for bedding and pot plants.

\section{Double Picotee}

8533 Picotee Shades Mixed. Same form as the Camellia type but each flower is a beautiful two-tone blend of pastel colors with a contrasting edge.

DORMANT BULBS, $11 \frac{1}{2}$ to 2 -inch tubers available from February 1 to March 15. 40c each; 3 of one variety for $\$ 1.10 ; 10$ of one variety for $\$ \mathbf{3 . 3 0}$.

See opposite page for amount to send for packing and postage.

MAIL ORDER INFORMATION

Include extra for packing and postage, the amount indicated below.

\section{DAHLIA TUBERS}

$18 \mathrm{c}$ for a total of 3 to 9 tubers. $30 \mathrm{c}$ for a total of 10 to 24 tubers. $40 \mathrm{c}$ for a total of 25 to 50 tubers. 


\section{Chrysanthemum Maximum SHASTA DAISY}

6699 Esther Reed. 18 in. This beautifully formed, fully double Shasta Daisy is much sought after for its lavish garden display and for its exceedingly delightful bouquets. The blooms are 3 inches across and pure white, borne on neat, vigorous plants. 3 for $\$ 1.25$; 10 for $\$ 3.50$ $50 \mathrm{c}$ each.

\section{PACIFIC HYBRID DELPHINIUM}

Since the introduction of this superb class of giant Delphiniums it has become everyone's favorite. The plants grow 6 feet tall and bear spikes with huge florets $21 / 2$ inches and more in diameter that are practically 100 per cent double. Our seed stock comes directly from the originator and our plants are of especially selected strains.

6728 Galahad Series. Large white flowers with white bees.

6729 King Arthur. One of the most brilliant Delphiniums. The color is rich royal purple with a velvety texture and a large white bee. The long spikes are strong and beautifully formed.

6721 Blue Bird. Nearest to true blue, with white bees. Excellent plant habit and tall graceful spikes.

6726 Summer Skies. Unequaled for cut flowers. Clear light heavenly blue with white bees.

\section{All Delphiniums,}

3 of one kind for $\$ 1.25 ; 10$ of one kind for $\$ 3.50 ; 50 \mathrm{c}$ ea.

\section{COREOPSIS}

6718 Sunburst. $2 \mathrm{ft}$. Highly prized for cut-flower decorations because of their long, graceful stems and exceptionally long-keeping quality. One of the few perennials that will bloom continuously when the flowers are kept cut. 3 for $\$ 1.00$; 10 for $\$ 2.80 ; 40 \mathrm{c}$ each.

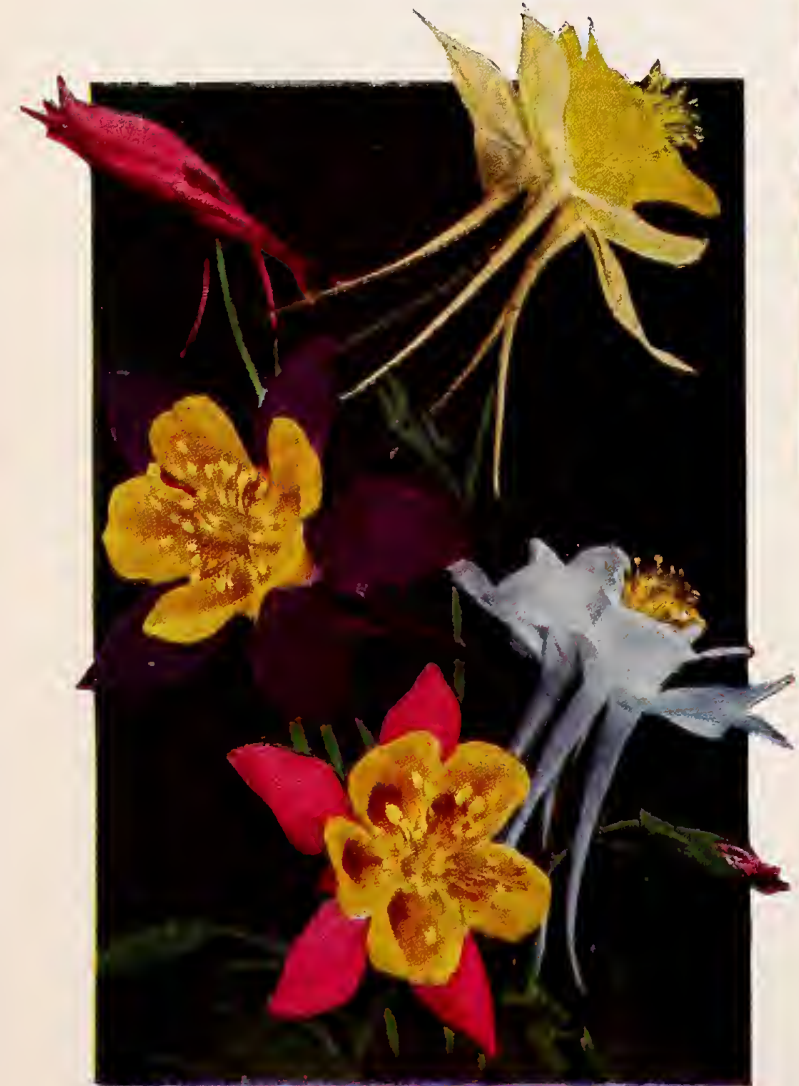

AQUILEGIA

Mrs. Scott Elliott's Long-Spurred Hybrids

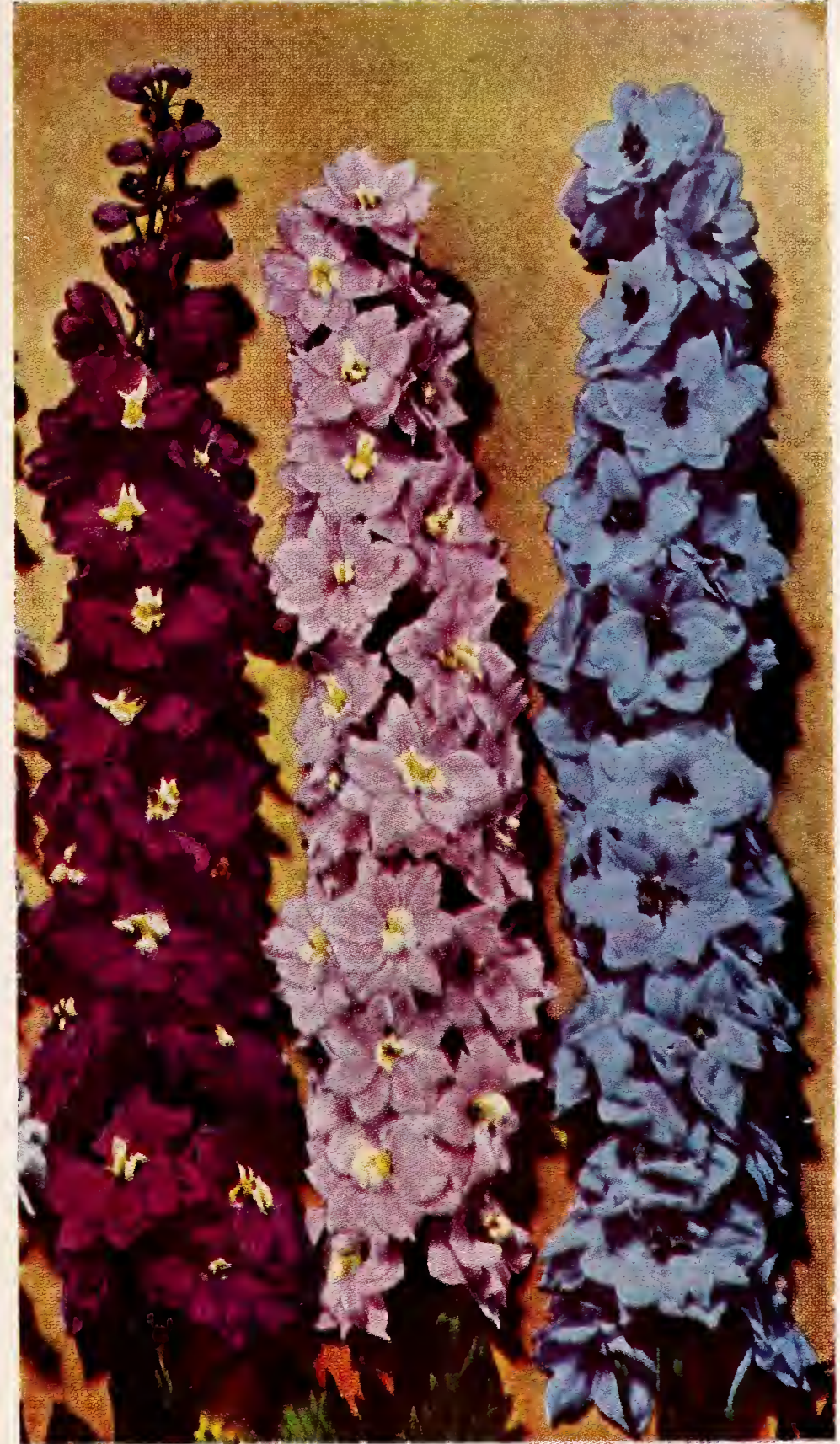

PACIFIC HYBRID DELPHINIUMS

\section{Aquilegia - COLUMBINE}

6622 Crimson Star. Most striking crimson sepaIs and spurs with a contrasting white center. An admirable subject in the garden. 3 for $\$ 1.00$; 10 for $\$ 2.80 ; 40$ c each.

6624 Mrs. Scott Elliott's Long-Spurred Hybrids. 26 in. Light and airy flowers poised gracefully on slender stems, bloom in a wonderful mixture of both rich and delicate colors. They are very hardy and thrive in sun or part shade. 3 for $\$ 1.00 ; 10$ for $\$ 2.80 ; 40 \mathrm{c}$ each.

\section{ARMERIA}

6629 Glory of Holland, 20 in. A new and improved form of Armeria. Tall straight stems carry $1 \frac{1}{2}$-inch, ball-like blooms of clear deep pink in May and June. A truly fine perennial. The blooms keep extra well when cut. 3 for $\$ 1.00 ; 10$ for $\$ 2.80 ; 40 \mathrm{c}$ each.

\section{GEUM}

6754 Mrs. Bradshaw. 18 in. Beautiful during the entire season, Softtextured foliage of richest green makes an appropriate base for the slender branched stems, which hold $11 / 2$ to 2 -inch flowers of a most satisfying shade of scarlet-red. Geum begins flowering in June and continues through summer. 3 for $\$ 1.00$; 10 for $\$ 2.80 ; 40 \mathrm{c}$ each. 


\section{Dewarf Edging and \\ Rock-Garden Plants}

\section{AJUGA}

$66056 \mathrm{in.}$ Very useful for rock gardens and ground covers, particularly in shady positions. Spikes of blue flowers in May and June. Packed in bunches of 10 plants for $\$ 1.00 ; 3$ bunches for $\$ 2.50 ; 10$ bunches for $\$ 7.70$. Include $30 \mathrm{c}$ additional for 3 bunches or $50 \mathrm{c}$ for 10 bunches for packing and postage.

\section{ALYSSUM}

6608 Saxatile compactum. Basket-of-Gold. $10 \mathrm{in.} \mathrm{The} \mathrm{brightest} \mathrm{yel-}$ low spring rock-garden flower. Blooms in April and May. 3 for $\$ 1.00$; 10 for $\$ 2.80 ; 40$ c each.

\section{Arabis . ROCK CRESS}

6628 Albida rosea. 5 in. A neat, charming plant completely covered in spring with delicate rosy pink flowers. Attractive silvery green foliage all summer. 3 for $\$ 1.00 ; 10$ for $\$ 2.80 ; 40$ c each.

6626 Snow Cap. 5 in. Dwarf, compact plants with dense masses of shining snow-white flowers. Bloons very early in the spring. 3 for $\$ 1.00 ; 10$ for $\$ 2.80 ; 40$ c each.

\section{AUBRIETA}

6646 Monarch Hybrids. 4 in. This is the large-flowered strain of this very colorful early spring-blooming perennial. Colors range from lavender to rich reddish purple. 3 for $\$ 1.00 ; 10$ for $\$ 2.80 ; 40 \mathrm{c}$ each.

\section{DORONICUM}

6751 Dwarf form. $10 \mathrm{in}$. This dainty miniature perennial produces its bright golden daisy-like flowers in early spring. Excellent rock-garden or low border plant. 3 for $\$ 1.00 ; 10$ for $\$ 2.80$; $40 \mathrm{c}$ each.

\section{PRIMULA - Primrose}

6960 Polyanthus, Giant Munstead Strain. 8 in. A wonderful improved strain of English origin, bearing giant flowers in niany new and desirable colors. 3 for $\$ 1.00 ; 10$ for $\$ 2.80 ; 40$ c each.

\section{DWARF SWEET WILLIAM}

6980 Midget Double. 5 in. Compact, bushy plants with broad clusters of flowers in many bright colors. 3 for $\$ 1.00 ; 10$ for $\$ 2.80$; 40 c each.

\section{Dianthus barbatus SWEET WILLIAM}

$697618 \mathrm{in.}$ Many rich and sparkling colors in early summer. 3 for $\$ 1.00$; 10 for $\$ 2.80$; 40 c each.

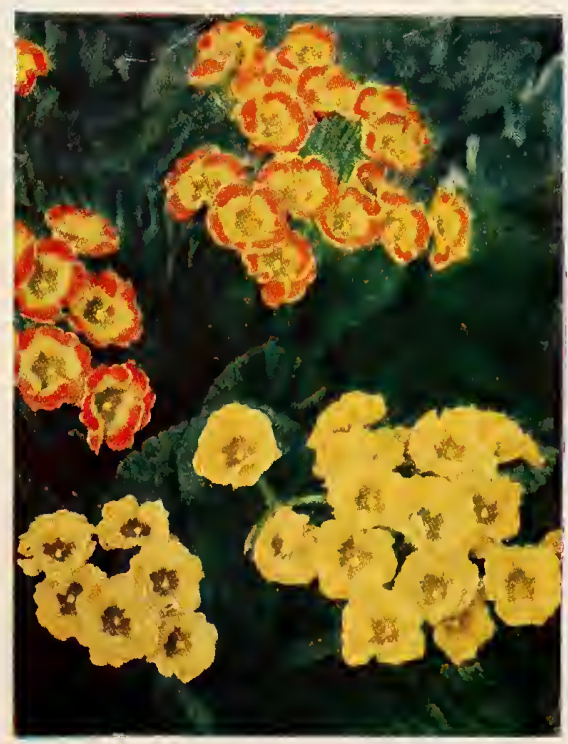

PRIMULA, Munstead Giants

\section{TEUCRIUM}

6984 Chamædrys. Dense, bushy plants with glossy evergreen foliage resembling dwarf boxwood. Pink flowers in summer. 3 for $\$ 1.00$; 10 for $\$ 2.80$; $40 \mathrm{c}$ each.

\section{VINCA}

6992 Minor. Grave Myrtle, 5 in Glossy evergreen foliage forming. a dense carpet, sprinkled with blue flowers. 3 for $\$ 1.00 ; 10$ for $\$ 2.80$; $40 \mathrm{c}$ each.

\section{VIOLET}

6996 Odorata. Sweet Violet. 6 in. The popular, well-known Violet. Single deep violet-blue flowers of exceedingly rich fragrance. 3 for $\$ 1.00 ; 10$ for $\$ 2.80$; 40 c each.

6997 Royal Robe. Extra large flowers of deepest violet-blue. They are delicately fragrant and open wide like a viola, often measuring up to 1 inch across. The sturdy plants form a mound of large leaves from which strong erect stems grow to 6 inches or more in length. 3 for $\$ 1.00 ; 10$ for $\$ 2.80 ; 40 \mathrm{c}$ each.

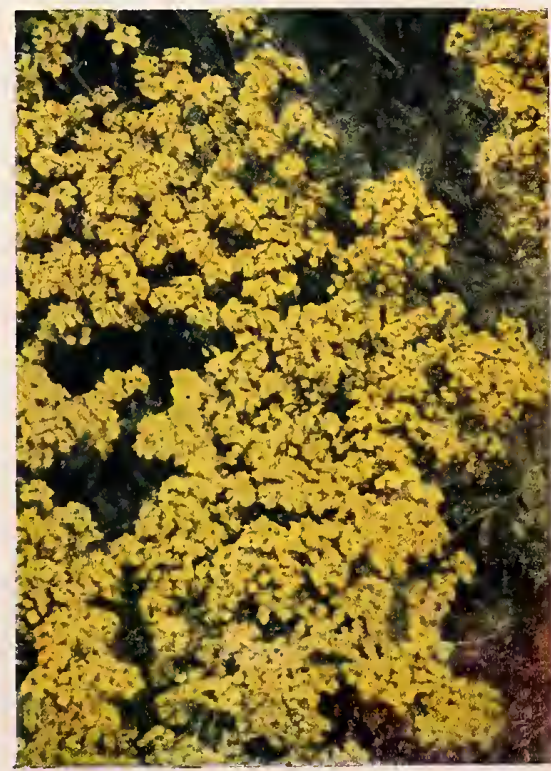

ALYSSUM saxatile 


\section{MOUNTAIN-GROWN SEEDS}

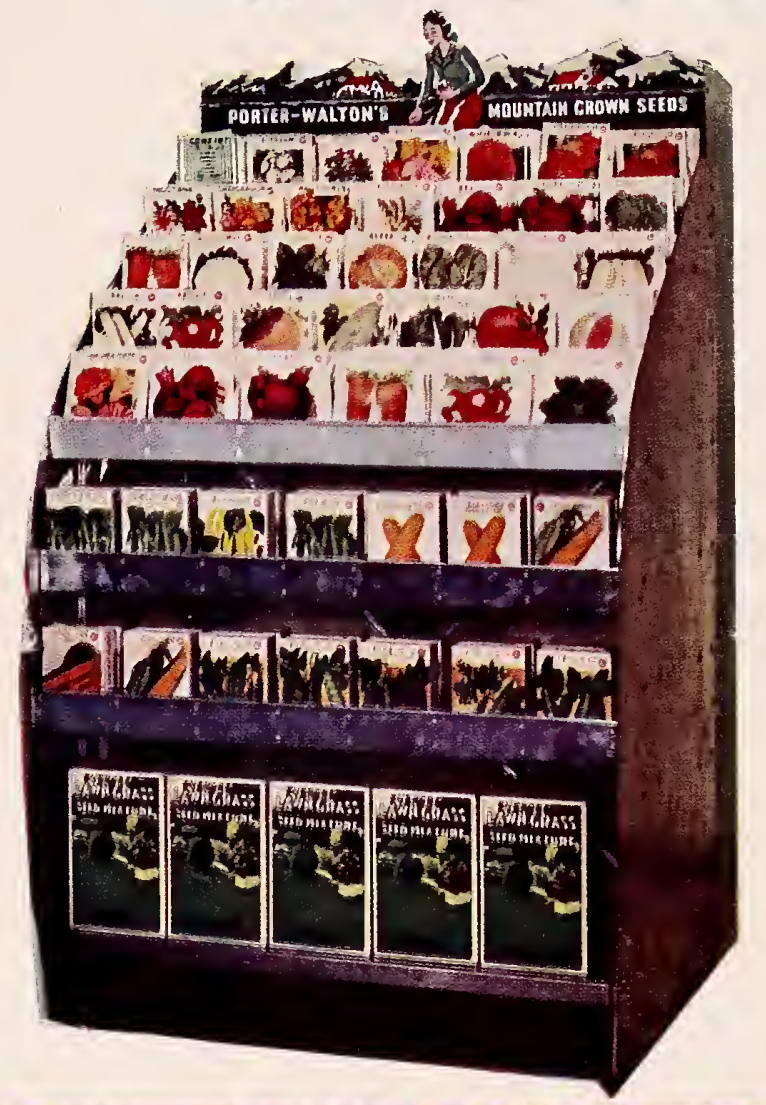

\section{Best for the West}

\section{Ask for them at your neighborhood store}

In the familiar Porter-Walton Seed Stand you will find all of the popular flower and vegetable seeds adapted to Intermountain sales and climate.

Your local store can also secure for you the new varieties illustrated here, as well as those in the yellow pages following.
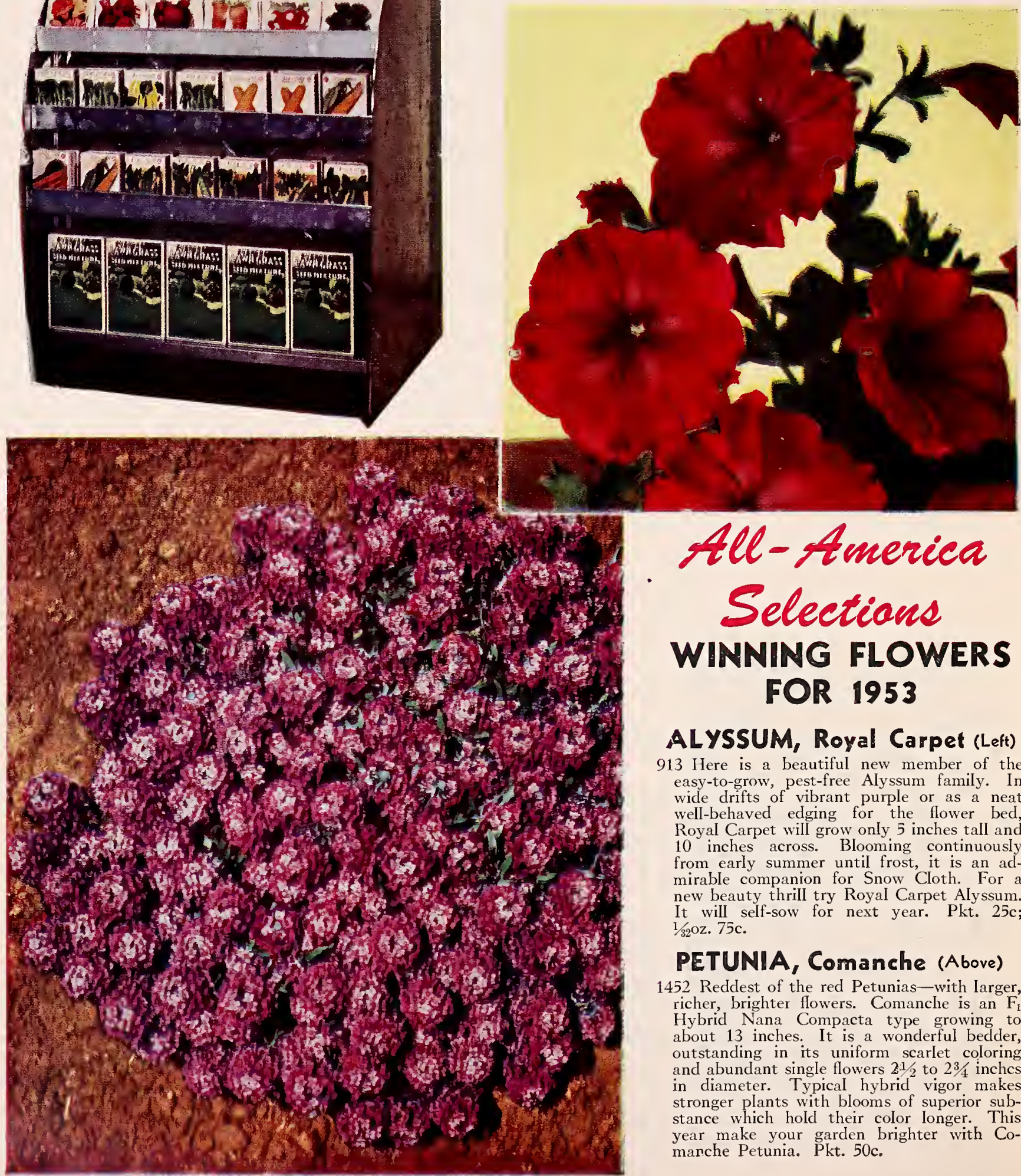

\section{All-America \\ Selections WINNING FLOWERS FOR 1953}

\section{ALYSSUM, Royal Carpet (Left)}

913 Here is a beautiful new member of the easy-to-grow, pest-free Alyssum family. In wide drifts of vibrant purple or as a neat well-behaved edging for the flower bed Royal Carpet will grow only 5 inches tall and 10 inches across. Blooming continuously from early summer until frost, it is an admirable companion for Snow Cloth. For a new beauty thrill try Royal Carpet Alyssum. It will self-sow for next year. Pkt. $25 \mathrm{c}$ $1 / 32 \mathrm{Oz} .75 \mathrm{c}$

\section{PETUNIA, Comanche (Above)}

1452 Reddest of the red Petunias - with Iarger, richer, brighter flowers. Comanche is an $F$ Hybrid Nana Compacta type growing to about 13 inches. It is a wonderful bedder, outstanding in its uniform scarlet coloring and abundant single flowers $21 \%$ to $23 / 4$ inches in diameter. Typical hybrid vigor makes stronger plants with blooms of superior substance which hold their color Ionger. This year make your garden brighter with $\mathrm{Co}$ manche Petunia. Pkt. 50c. 


\section{Porter-Walton's ANNUAL FLOWER SEED Price List}

\section{MAIL-ORDER INFORMATION}

All filower seeds are priced f.o.b. Salt Lake City, Utah. If the total weight of all flowers seeds ordered is $1 / 2$ to 1 pound, send $20 \mathrm{c}$ additional for postage and packing.

AFRICAN DAISY

900 Mixed.

\section{AGERATUM}

904 Midget Blue.

906 Blue Perfection

ALYSSUM

912 Little Gem...............\$0 10

914 Snow Cloth.............. 10

913 Royal Carpet (AAS 1953) ...... 25

916 Violet Queen.............. 15

\section{ANTIRRHINUM}

943 Tetra White Rose.................

945 Tetra Deep Salmon-Pink.............

946 Tetra Bright Rose................

944 Tetra Mixed.

949 Dwarf Magic Carpet Mixed.

\section{ASTERS (Wilt ResIstant)}

951 Princess Ann. Peach blossom......... 15

953 Princess Barbara. Orchid ............. 15

957 Princess Elizabeth. White........... 15

961 Princess Pat. Crimson................ 15

955 Princess Mixture................ 15

991 Super Giant, Beverly Hills. Azure . . . . . 15

993 Super Giant Hollywood. White......... . 15

994 Super Giant El Monte. Crimson ......... 15

995 Super Giant Pasadena. Peach blossom.... 15

998 Super Giant Mixed. . . . . . . . . . . 15

BALSAM

1006 Double Camellia-FI.

Pkt. 1/80z. 1/40z.

$\$ 015 \$ 035 \$ 055$

CALENDULA

Pkt.

1015 Lemon Queen

$\$ 010$

1016 Orange King.

1018 Db. Giant Mxd.................. 10

\section{CALIFORNIA POPPY}

1023 Orange King

\section{CALLIOPSIS}

1032 Finest Mxd.

\section{CANDYTUFT}

Pkt. 1/80z. 1/40z. Oz.

1036 Giant Hyacinth White.

1038 Umbellata Finest Mrd........ 10

\section{CARNATIONS}

1040 Giant Marguerite Mxd..............

\section{CELOSIA}

Pkt.

1044 Chinese Woolflower..........\$0 10

1046 Crested Dwarf Mxd........... 15

1048 Tall Royal Velvet............ 10

1050 Plumosa Finest Mxd.......... 15

1047 Golden Fleece (New).......... 25

CENTAUREA CYANUS

Pkt.

1054 Blue Boy................\$0 10

1055 Red Boy................ 10

1056 Dwarf Jubilee Gem......... 10

1058 Mixed.................... 10

1060 Imperialis Mxd.............

CHEIRANTHUS

1070 Golden Bedder.

CLARKIA

1080 Elegans Db. Mxd.

$\$ 025 \$ 045$

$55 \$ 090$

$60 \quad 110$

30

30

30

30

30

45

45

45

45

45

Oz.

$\$ 075$

$20 \quad 60$

25

65

100

$\$ 150$

$25 \quad 80$

Pkt. 1/160z. 1/80z.

$\begin{array}{llllll}\$ 0 & 15 & \$ 0 & 40 & \$ 0 & 70\end{array}$

1/160z. 1/80z. 1/40z. $\$ 045 \$ 080$

$\$ 030 \quad 50$

$30 \quad 50$

35

65
$60-85$

1/80z. 1/40z. Oz.

$\$ 025 \$ \$ \quad 75$

$\begin{array}{lll}\$ 025 & 25 & 75\end{array}$

75

Pkt. 1/80z. 1/40z.

\$0 $10 \quad \$ 0 \quad 25 \quad \$ 040$
CLEOME

1083 Pink Queen.

Pkt. 1/160z. 1/80z.

$\$ 015 \$ 025 \$ 045$

\section{cosmos}

1106 Early DJ. Crested...........\$0 15 $\$ 040 \quad \$ 060$

1110 Fiesta.

1114 Sensation, Dazzler Crimson ... 15

1118 Sensation, Pinkie........... 15

1120 Sensation, Purity White...... 15

1122 Sensation, Radiance.......... 15

1124 Sensation Mixed............ 15

\section{CYNOGLOSSUM}

1130 Firmament (Chinese Forget-Me-Not).

DAHLIA

1127 Unwin Dwarf Hybrids. .

Pkt. 1/160z. 1/80z.

\section{DIANTHUS}

1134 Best DЫ. Mxd.

1137 Gaiety Single.

FOUR O'CLOCKS

1148 Mirabilis Mixed.

\section{GODETIA}

1158 Dwarf Sgl. Mixed.

\section{GOURDS}

1164 AII Varieties Mrd.

\section{G YPSOPHILA}

1168 Elegans Covent Garden........\$0 10

1169 Carminea ................ 10

\section{HELICHR YSUM}

1170 Strawflower Mxd..

\section{HELIANTHUS}

1175 Sungold.

\section{KOCHIA}

1180 Childsii (Mexican Fire Bush).

\section{LARKSPUR}

1190 Salmon Supreme.

1202 Blue Spire.

1204 Lilac King. . . .

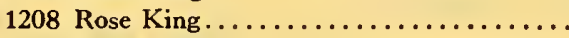

1210 White King.

1218 Giant Imperial Mrd.

LOBELIA

1224 Crystal Palace Compacta.

MARIGOLDS

1264 All Dbl. African Mix........... 10

1262 Mammoth Mum............. 15

1267 Dwarf Cupid............... 25

1268 Dwarf Spry................ 10

1275 Midget Harmony............ 10

1279 Dwf. Naughty Marietta........ 10

1280 Sunkist................... 10

1284 Gnome................. 10

\section{MORNING GLORIES}

Pkt.

1291 Crimson Rambler............. \$0 10

1294 Pearly Gates:................ 15

1298 Heavenly Blue............. 15

1300 Mixed Colors
1253 Sunset Giants. . . . . . . . . \$0 10
$\$ 015 \$ 025 \$ 045$

1/160z. 1/80z. 1/40z. $\$ 025 \$ 040$

Pkt. 1/40z. Oz.

$\$ 0 \quad 15 \$ 020 \quad \$ 065$

Pkt. 1/80z. 1/40z. .$\$ 010 \$ 035 \$ 060$

Pkt. Oz. \$0 $15 \$ 035$

1/40z. Oz. 1/4lb. $\$ 040 \$ 125$

$\$ 065200$

Pkt. 1/80z. 1/40z. $\$ 010 \$ 035 \$ 055$

Pkt. 1/40z. Oz. $\$ 015 \$ 025 \$ 095$

Pkt. 1/20z. Oz. $\$ 0 \quad 10 \quad \$ 0 \quad 20 \quad \$ 035$

Pkt. $1 / 80 z$. 1/40z.

\$0 $10 \quad \$ 0 \quad 40 \quad \$ 060$

$40 \quad 60$

$40 \quad 60$

$40 \quad 60$

$40 \quad 60$

Pkt. 1/160z. 1/80z.

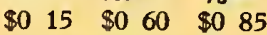

1/160z. 1/80z. 1/40z. $\$ 045 \$ 080$

$60 \quad 85$

$90 \quad 150$

45

80

80

1/80z. 1/40z. Oz. $\$ 020 \$ 075$

$\begin{array}{llll}\$ 0 & 25 \quad 45 \quad:\end{array}$

Pkt. Oz. 1/4lb. $\begin{array}{llll}\$ 0 & 10 \quad \$ 0 \quad 40 \quad \$ 125\end{array}$
$\$ 025 \quad 40$ 


\section{NASTURTIUMS}

1310 Tall Single Mxd.

1314 Dwarf Single Mxd..................

1324 Semi-Double Golden Gleam..........

1328 Semi-Double Scarlet Gleam. ...........

1332 Semi-Double Gleam Hybrids Mixed....

\section{NICOTIANA}

1370 Affinis Choice Mxd.

\section{PANSIES}

1384 Roggli's Swiss Giants

1387 Steele's Jumbo

\section{PANSIES, SWISS GIANTS}

1398 Berna, velvety blue...............

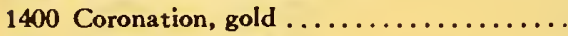

1402 Alpenglow, garnet red..............

1404 Rhinegold, yellow-dark center .......

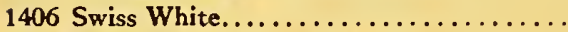

1408 Lake of Thun, blue-dark center .......

1409 Raspberry Rose.................

Pkt. Oz. 1/4lb.

$\$ 0 \quad \$ 035 \$ 090$

$\begin{array}{lll}10 & 35 & 90\end{array}$

$\begin{array}{llll}15 & 45 & 1 & 25 \\ 15 & 45 & 1 & 25\end{array}$

$15 \quad 45 \quad 125$

$15 \quad 45-125$

Pkt. 1/80z. 1/40z. .\$0 $10 \quad \$ 0 \quad 25 \quad \$ 0 \quad 35$

Pkt. $1 / 320 x$. $1 / 100 x$. .$\$ 0 \quad 50 \quad \$ 200 \quad \$ 375$ $\begin{array}{lllll}50 & 1 & 75 & 3 & 25\end{array}$

\section{VIOLAS}

Pkt. 1/320z. 1/100x.

1410 Chantreyland, apricot .......\$0 $50 \quad \$ 075 \quad \$ 130$

1414 Blue Perfection............. 50 $75 \quad 130$

1416 Lutea Splendens, yellow....... $50 \quad 75 \quad 130$

1420 Mixed.................. 15

1412 Arkwright Ruby........... 50

\section{PETUNIA NANA Compacta}

1432 Celestial Rose.

1460 Violacea

.........

Pkt.

$\$ 015 \quad 050$ 1/160z.

$175 \$ 275$

1440 Rosy Morn Imp.

Pkt. $1 / 40 z$.

.\$0 $15 \$ 135$

Pkt. $1 / 320 z$.

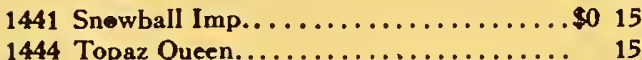

1446 Fire Chief. .

1445 Nana Compacta Mrd.

$\$ 050$

50

200

\section{PETUNIA, Multifiore Hybrld}

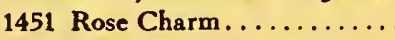

1452 Comanche Red (AAS 1953).

\section{RUFFLED PETUNIA}

Pkt. $1 / 040 z$. $1 / 320 z$.

1422 Dwf. Giants of Calif. .

$\$ 0 \quad 50 \quad \$ 325 \quad \$ 600$

1426 Ruffled Monsters. 90 25
60

\section{PETUNIAS, LARGE FL. SINGLE}

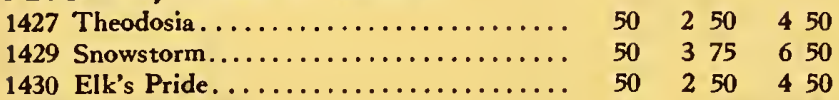

1421 Ballerina..................... 100

\section{PETUNIAS, GIANT ALL-DOUBLE}

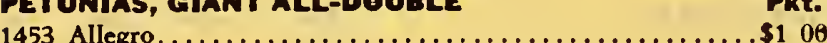

1455 Caprice.............................. 100

1457 Minuet................................ 100

1459 Nocturne.............................. 100

1461 Sonata............................... 100

1447 All-Double Glorious Mrd................. 100

\section{PHLOX}

1462 Drummondi Mxd...........\$0 15

1463 Star Phlox Mxd............. 15

1466 Globe Mixed (New).

25

1470 Single Shirley....

1472 Shirley, Db. Mxd.

1474 Shirley, Sgl. Mxd. .

\section{PORTULACA}

1480 Sgl. Mxd. (Moss Rose).

1490 Db. Mxd. (Moss Rose)

Pkt. 1/160z. 1/80z.

RICINUS (Castor Bean)

Pkt. $1 / 20 z$. Ox. 1500 Zanzibarensis Mxd............... \$0 15 \$0 $20 \quad \$ 035$

\section{SALPIGLOSSIS}

1504 Emperor Mxd.

Pkt. $1 / 80 z$. 1/40z.

\section{SALVIA}

1520 America .

Pkt. $1 / 320 z$

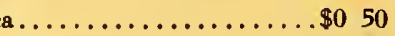

1521 Blaze of Fire............. 50

1525 Splendens................ 15

$\$ 070 \$ 100$

1/160z. $1 / 80 z$.

SCABIOSA

Pkt. $1 / 160 z$. 1/80z. $1 / 40 z$. 1530 Blue Moon................\$0 $15 \$ \$ 40 \$ 075$

1540 Giant Hyb. Mxd............. 10

$25 \$ 045$

Oz. 1/4lb. Lb. SCARLET RUNNER BEAN $1542 \ldots \ldots \ldots . \$ 0 \quad 10 \quad \$ 0 \quad 30 \quad \$ 090$ sTocks

1620 Imp. Large Fl.

Pkt. 1/80z. 1/40z. TITHONIA

1640 Torch.

Pkt. 1/160z. 1/20z. VERBENA

Pkt. 1/320z. 1/160z. 1/80z. 1652 Mixture of Giants........... \$0 $10 \quad \$ 0 \quad 25 \quad \$ 0 \quad 40 \quad \$ 075$

SWEET PEAS, Summer-Flowering Pkt. Oz, 1/4b. 1 to 4

1580 Bonnie Briar. Rose-pink.......\$0 15 1582 Capri. Silver-blue ........... 15 1588 Flora. Deep Iavender........ 15 1590 Golden Dragon............... 15 1598 Rubicund. Scarlet-crimson.... 15 1600 Snow-White. Solid paper wh.... 15 1604 Welcome. Dazzling scarlet..... 15 1610 Silver Medal Blend......... 15

\section{SWEET PEAS, CUTHBERTSON}

1613 Cuthbertson Mixed......... 15

1614 Coline. Scarlet. . . . . . . . . 15

1615 Evelyn. Salmon-cream-pink.... 15

1616 Frank G. Lavender........... 15

1617 Janet. White............. 15

1618 Lois. Clear rose-pink........ 15

1619 Tommy. Clear marine-blue..... 15

\section{ZINNIAS, Dahlla-Flowered}

Pkt. 1/80z. $1 / 40 z$. 1680 Canary Bird. Yellow. .

.$\$ 015 \$ 035$

1682 Crimson Monarch. Deep crimson ...... 15

1684 Dream. Deep rosy lavender.......... $15 \quad 35$

1685 Oriole. Orange and gold............... $15 \quad 35$

1686 Exquisite. Light rose............... $15 \quad 35$

1690 Polar Bear. White................. 15

1696 Gold Medal Mixture................ $10 \quad 35$

Cactus and Minlature Types

1702 New Giant Cactus Hybrid............ 25

1706 Floradale Scarlet................. 15

1710 New Peppermint Stick.............. 25

1712 Lilliput or Pompon Choice Mixed....... 10

1714 Tom Thumb................... 15

1721 Persian Carpet................ 25
550

550

550

550

550

550

550

$\$ 065$ 65 


\section{Porter-Walton's Bulk Prices for Vegetable Seeds}

\section{MAIL-ORDER INFORMATION}

All vegetable seeds are priced f.o.b. Salt Lake City, Utah. Based on the total weight of all the seeds on your order, send an additional amount for packing and postage according to the following schedule:

For 1 Ib., 20c; for 5 Ibs., 35c; for 10 Ibs., 50c; for 20 Ibs., 90c; for 30 Ibs., $\$ 2.25$.

BEANS. Any variety, 6-0z. pkt. 25c; economy carton 42c.

\section{5 to 910 to 2425 to 99100}

lbs. lbs. Ibs. Ibs.

per Ib. per Ib. por Ib. per Ib.

27 Topcrop..................\$0 $36 \quad \$ 033 \quad \$ 030 \quad \$ 028$

30 Tendergreen................ $35 \quad 32 \quad 29 \quad 27$

32 Landreth's Stringless, Burpee's Impr.................... 29

29 New Wade.............. 42

36 Wax Pencil-Pod............ 32

39 Cherokee Wax............. 36

40 Pole Blue Lakes............. 35

44 Pole Kentucky Wonder........ 34

50 Broad Windsor............ 37

58 Bush Lima, Fordhook........ 37

60 Bush Lima, Henderson's........ 32

62 Pole Lima, King of the Garden.... 37

HYBRID CORN. Any varlety, 4-oz. pkt. 25c; economy carton $49 \mathrm{c}$.

170 Marcross C $6 \times 13 \ldots \ldots \ldots \ldots \ldots, 45$

171 Carmelcross.............. 45

174 Golden Cross Bantam......... 40

179 Iochief.................. 52

173 Stowell's White........... 48

$\begin{array}{llr}42 & 39 & 371 / 2 \\ 42 & 39 & 371 / 2 \\ 38 & 35 & 33 \\ 49 & 46 & 44 \\ 45 & 42 & 40\end{array}$

CORN, OPEN-POLLINATED. Any varlety, 6-0z." carton 25c; economy carton 33c.

180 Golden Bantam ............. $28 \quad 25 \quad 22 \quad 20$

186 Golden Sunshine............ $28 \quad 25 \quad 22 \quad 20$

CORN, HYBRID POP

197 Iopop................ $75 \quad 70 \quad 65 \quad 60$

PEAS. Any varlety, 6-0z. carton 25c; economy carton 33c.

\section{5 to 910 to 2425 to 99100}

lbs. Ibs. Ibs. lbs.

per ib. per ib. por ib. per Ib.

380 Alaska Smooth-pod...........\$0 21 \$0 18 \$0 16 \$0 14

$\begin{array}{llllll}382 & \text { Bliss Everbearing.............. } 26 & 23 & 21 & 19\end{array}$

384 Dwarf Alderman............ $29 \quad 26 \quad 23 \quad 21$

386 Giant Stride.............. $29 \quad 26 \quad 23 \quad 21$

390 Laxton's Progress............ $29 \quad 26 \quad 23 \quad 21$

392 Little Marvel................ $29 \quad 26 \quad 23 \quad 21$

395 Perfection................ $27 \quad 24 \quad 21 \quad 19$

396 Stratagem Improved.......... 29 $29 \quad 26 \quad 23 \quad 21$

398 Victory Freezer.............. $30 \quad 27 \quad 24 \quad 22$

\section{ASPARAgUS}

Pkt. Oz. 1/1/b. Lb. 10 Mary Washington............ $\$ 0 \quad 15 \quad \$ 0 \quad 20 \quad \$ 0 \quad 60 \quad \$ 175$

\section{BEETS}

$\begin{array}{lllllll}80 & \text { Detroit Dark Red . . . . . . . . . } & 10 & 20 & 50 & 1 & 10 \\ 82 & \text { Early Blood.................. } & 10 & 20 & 50 & 1 & 10\end{array}$

85 Green-Top Bunching......... $10 \quad 20 \quad 50 \quad 110$

\section{MANGELS}

87 Corona.

\section{BROCCOLI}

90 Italian Green Sprouting........

\section{BRUSSELS SPROUTS}

94 Long Island Improved.
cabBage

102 Danish Ballhead. .

100 Copenhagen Market.

104 Jersey Wakefield. .

106 Golden Acre..

107 Green Acre. . .

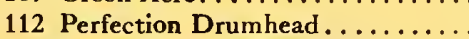

Pkt.

Oz. 1/4lb. Lb.

114 Red Stonehead.

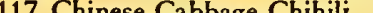

.$\$ 010$

10

$\$ 0 \quad 45 \quad \$ 135 \quad \$ 400$

$\begin{array}{llll}30 & 90 & 2 & 10\end{array}$

$\begin{array}{llll}30 & 90 & 2 & 10\end{array}$

$\begin{array}{llll}30 & 90 & 2 & 10\end{array}$

$\begin{array}{llll}30 & 90 & 2 & 10\end{array}$

$\begin{array}{llll}30 & 90 & 2 & 10\end{array}$

$\begin{array}{lllll}40 & 1 & 10 & 3 & 30\end{array}$

$\begin{array}{lllll}40 & 1 & 10 & 3 & 30 \\ 20 & & 60 & 1 & 75\end{array}$

\section{CARROTS}

124 Nantes Coreless. . . . . . . . . . . 10

127 Imperida.................. 10

122 Chantenay Red Cored.......... 10

128 Danvers Half-Long. . . . . . . . . 10

132 Improved Long Orange........ 10

134 Short White or Mastodon.........

10

\section{CAULIFLOWER}

146 Snowball No. $16 \ldots \ldots \ldots \ldots \ldots .15$

142 New Snowdrift............. 15

$\begin{array}{llllll}250 & 6 & 75 & 17 & 50\end{array}$

\section{CELERY}

150 Improved Utah............. 15

$150 \quad 400 \quad 1100$

\section{CELERIAC}

156 Giant Smooth Prague.......... 10

$\begin{array}{llll}75 & 2 & 25 & 600\end{array}$

\section{CHICORY}

162 Large Rooted or Coffee......... 15

163 Witloof................. 15

Chives $166 \ldots \ldots \ldots \ldots \ldots \ldots \ldots$

$\begin{array}{lllll}35 & 1 & 15 & 3 & 50\end{array}$

$\begin{array}{lllll}35 & 1 & 15 & 3 & 50\end{array}$

CUCUMBERS

202 Boston Pickling............ 10

203 Colorado................... 10

206 Improved Long Green.......... 10

204 Cubit.............................. 10

207 Marketer.

\section{COllards}

216 Georgia Southern............. 10

\section{CRESS OR PEPPERGRASS}

218 Early Curled.............. 15

$100 \quad 350 \quad 1000$

\section{EGGPLANT}

220 Black Beauty............. 15

\section{ENDIVE}

226 Batavian Full Hearted......... 15

228 Green Curled.............. 15

\section{HERBS}

240 Anise................. 15

242 Caraway................. 15

245 Coriander................ 15

253 Sweet Basil................. 15

244 Catnip................. 15

251 Rosemary................. 15

246 Dill..................... 10

248 Fennel. . . . . . . . . . . . . . 15

250 Horehound................ 15

252 Sweet Marjoram............ 15

15

$35 \quad 100$ 
PORTER-WALTON'S BULK PRICES for VEGETABLE SEEDS, continued

KALE

260 Dwarf Curled Scotch..........\$0 $10 \quad \$ 0 \quad 20 \quad \$ 0 \quad 50 \quad \$ 1 \quad 50$

\section{KOHLRABI}

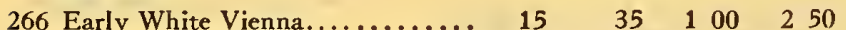

\section{LEEK}

270 Emperor.

\section{LETTUCE}

271 Premier Great Lakes.......... 15

272 Great Lakes.............. 15

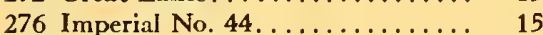

280 New York No. 12.......... 15

283 Salad Bowl. .............. 15

282 Hanson Head............. 10

286 Loose-Leaved Early Curled Simp-

son..................... 10

288 Loose-Leaved Prizehead......... 10

289 Romaine $($ Cos) ............. 10

\section{MUSTARD}

294 Giant Southern Curled......... 10

297 Large Smooth Leaf. .......... 10

\section{MUSKMELONS}

300 Casaba, Golden Beauty........ 15

306 Honey Dew.................. 15

315 Cranshaw................. 15

325 Granite State.............. 15

304 Hale's Best No. 45........... 15

308 Hearts of Gold.

310 Hale's Best No. 936 Jumbo Strain.

\section{WATERMELON}

322 Kleckley Sweet No. 6........ 10

326 Green Klondike R-7. . . . . . . . 10

328 Striped Klondike............ 10

330 New Midget Hampshire....... 25

$332 \mathrm{King}$ and Queen............ 10

\section{OKRA}

342 Clemson Spineless. .......... 10

\section{ONION}

350 Yellow Sweet Spanish (Not Cert.).

352 Yellow Sweet Spanish (Cert.).

356 Mountain Danvers.............

358 Crystal White Wax............

360 Southport White Globe..........

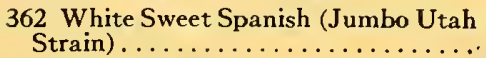

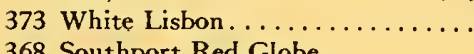

368 Southport Red Globe...........

372 White Portugal Silverskin...... 15

$\begin{array}{llll}60 & 175 & 500\end{array}$

$\begin{array}{lllll}50 & 1 & 50 & 4 & 00 \\ 50 & 1 & 50 & 4 & 00 \\ 40 & 1 & 10 & 3 & 00 \\ 40 & 1 & 10 & 3 & 00 \\ 50 & 1 & 50 & 4 & 00 \\ 20 & & 70 & 1 & 85 \\ & & & & \\ 20 & & 70 & 1 & 85 \\ 20 & & 70 & 1 & 85 \\ 20 & & 70 & 1 & 85\end{array}$

$\begin{array}{llll}20 & 35 & 1 & 00\end{array}$

$\begin{array}{lll}80 & 2 & 10\end{array}$

$40 \quad 100 \quad 300$

$\begin{array}{lllll}40 & 1 & 00 & 3 & 00\end{array}$

$\begin{array}{llll}30 & 80 & 2 & 00\end{array}$

$30 \quad 80 \quad 200$

$\begin{array}{llll}30 & 80 & 2 & 00\end{array}$

\begin{tabular}{|c|c|c|}
\hline 20 & 60 & \\
\hline 25 & 70 & \\
\hline & 70 & \\
\hline 45 & 100 & \\
\hline & 60 & \\
\hline
\end{tabular}

\section{ONION SETS}

376 Yellow

1 to 45 to 2425 to 4950 lbs. perlb. perib.perlb. perib. $\begin{array}{llllllll} & & & \end{array}$

\section{PARSLEY}

Pkt. Oz. 1/4lb. Lb. 402 Champion Moss Curled......... $\$ 0 \quad 10 \quad \begin{array}{llllllll} & 20 & \$ 0 & 50 & \$ 1 & 35\end{array}$ 405 Hamburg Rooted........... $10 \quad 20 \quad \begin{array}{rrr}50 & 1 & 35\end{array}$

\section{PARSNIPS}

410 White Model.

10

20

40

110

\section{PUMPKINS}

412 Connecticut Field............ 10 418 Sugar Pie.

600

$\begin{array}{lllll}40 & 1 & 25 & 3 & 50\end{array}$

$\begin{array}{lllll}50 & 1 & 25 & 3 & 25\end{array}$

$\begin{array}{lllll}50 & 1 & 65 & 5 & 00\end{array}$

$\begin{array}{llll}65 & 200 & 5 & 50\end{array}$

$\begin{array}{lllll}50 & 1 & 25 & 3 & 50\end{array}$

$\begin{array}{lllll}40 & 1 & 25 & 3 & 50\end{array}$

\section{PEPPERS}

420 California Wonder.

Pkt. Oz. 1/4lb. Lb.

430 Long Red Cayenne.......... $15 \quad 75 \quad 200 \quad 625$

$\begin{array}{lllll}15 & 75 & 200 & 625\end{array}$

436 Red $C h i l i \ldots \ldots \ldots \ldots \ldots \ldots .15 \quad 100 \quad 300 \quad 850$

$\begin{array}{llll}75 & 2 & 75 & 700\end{array}$

RADISHES. 5 to 24 lbs. one variety deduct $10 \mathrm{c}$ per lb. 25 to 99 lbs. one variety deduct $20 \mathrm{c}$ per lb.

450 Comet.................. 10

455 Cavalier................... 10

452 Sparkler, White Tip............ 10

458 Early Scarlet Globe............ 10

466 Winter Celestial. . . . . . . . . . . 10

451 Cherry Belle.

$25 \quad 45 \quad 75$

25

25

25

25

25

$45 \quad 75$

$45 \quad 75$

$45 \quad 75$

$55 \quad 120$

SAGE

480 Officinalis.

15

$\begin{array}{llll}80 & 225 & 650\end{array}$

SALSIFY

486 Mammoth Sandwich Island..... $10 \quad 55 \quad 150 \quad 450$

\section{SPINACH}

490 Bloomsdale Long-Standing...... 10

494 King of Denmark............. 10

489 America.

20

20

25

30

30

\section{SWISS CHARD}

496 Fordhook Giant

498 Rhubarb Chard.

10

$20 \quad 40 \quad 100$

\section{SQUASH}

506 Early White Bush.......... 10

510 Yellow Summer Crookneck...... 10

512 Zucchini Black............. 15

503 Caserta...................... 15

514 Winter Banana Pink.......... 15

516 Chicago, Warted Hubbard....... 15

522 Golden Hubbard........... 15

524 Mammoth Table Queen........ 15

519 Butternut................. 15

517 Buttercup................ 15

525 Uconn Bush............... 10

\section{TOMATOES}

526 New V-R 4 Moscow......... $25 \quad 150 \quad 450 \quad 1200$

530 Early Canner.............. $15 \quad 140 \quad 4 \quad 00 \quad 1100$

532 Marglobe..................... $15 \quad 60 \quad 175 \quad 550$

544 Rutgers................. $15 \quad 60 \quad 175 \quad 550$

540 Stokesdale..................... $15 \quad 60 \quad 175 \quad 550$

536 Earliana Special............. $15 \quad 80 \quad 250 \quad 700$

537 Indiana Baltimore............. $15 \quad 50 \quad 150 \quad 500$

527 New V-R 11 Stone............ $25 \quad 150 \quad 450 \quad 1200$

SMALL-FRUITED TOMATOES

Pkt. Oz. $1 / 4 \mathbf{l b}$.

548 Red Pear....................... \$0 $15 \$ 100 \$ 300$

546 Red Cherry......................... 15 $100 \quad 300$

550 Yellow Pear.................... $15 \quad 100 \quad 300$

554 Ground Cherry................... $15 \quad 100 \quad 300$

556 Huckleberry.................... $15 \quad 100 \quad 300$

\section{TURNIPS}

560 Purple-Top White Globe
Pkt. 0z. $1 / 4$ lb. Lb.

\section{RUTABAGA} $\begin{array}{llllll}570 & \text { American Purple-Top........... } & 10 & 25 & 40 & 75 \\ 578 \text { Laurentian................. } & 10 & 25 & 40 & 75\end{array}$ 


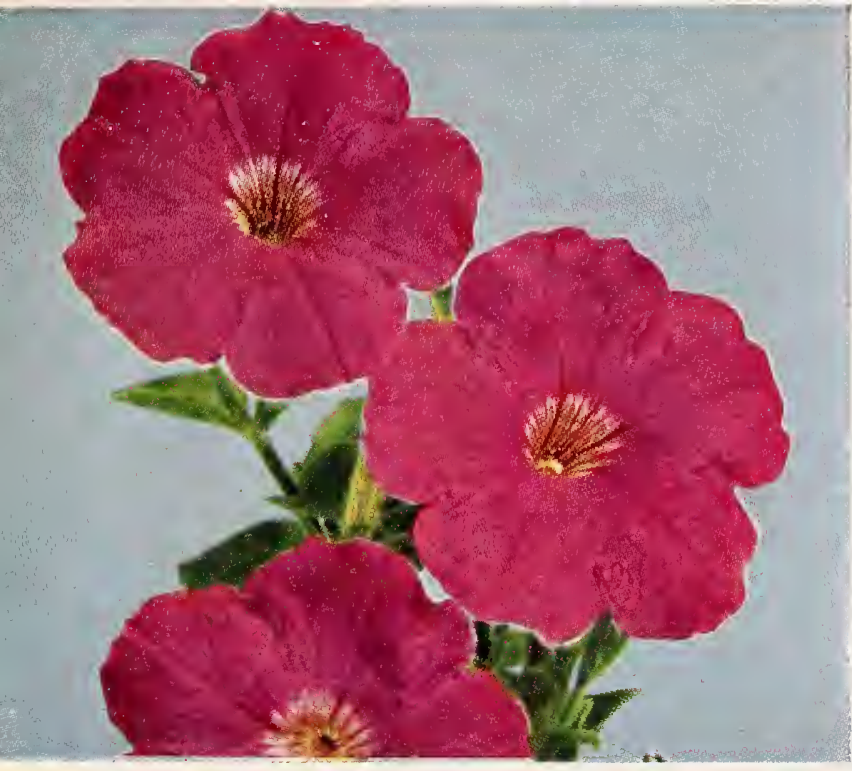

\section{THREE Outstanding Neu FLOWERS}

\section{FOR RICHER GARDEN DISPLAY}

\section{PETUNIA, LIPSTICK}

1454 A new dwarf bedding Petunia with an unusual glowing colorcarmine-rose overlaid with a touch of salmon. It is deeper and richer than Celestial Rose. The plants are compact, early blooming and extremely free-flowering, bearing $2 \frac{1}{2}-$ inch, single flowers. Pkt. 50c.

\section{CELOSIA GOLDEN FLEECE}

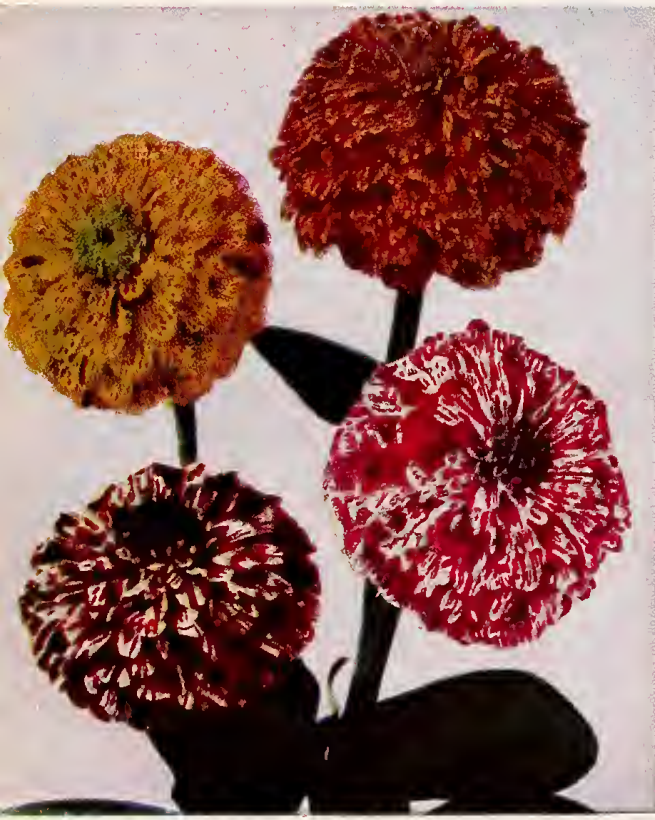

1047 A giant form of the plumed Cockscomb, the new Golden Fleece is really unusual and beautiful. It is easy to grow, germinates quickly, blooms early and stands any amount of ho weather. The large, dense plumcs have long stems, which when cut are generously replaced by several more. Grow Golden Fleece for cut flowers and as a showy border plant. Pkt. 25c.

\section{Spectacular New Zinnia} PEPPERMINT STICK $\longleftarrow$ MIXED

171020 in. Another distinct new Zinnia from the pumila or cut and come-again class. Compact branching plants bloom from midsummer until frost if kept picked. The fully double, well-rounded blooms, about $2 \frac{1}{2}$ inches across, come in a wide range of colors beautifully striped red and whitc and many more appealing combinations. Peppermint Stick produces about 70 per cent striped flowers. Pkt. 25c; $1 / 8$ oz. 50c; $1 / 4$ oz. $90 \mathrm{c}$.

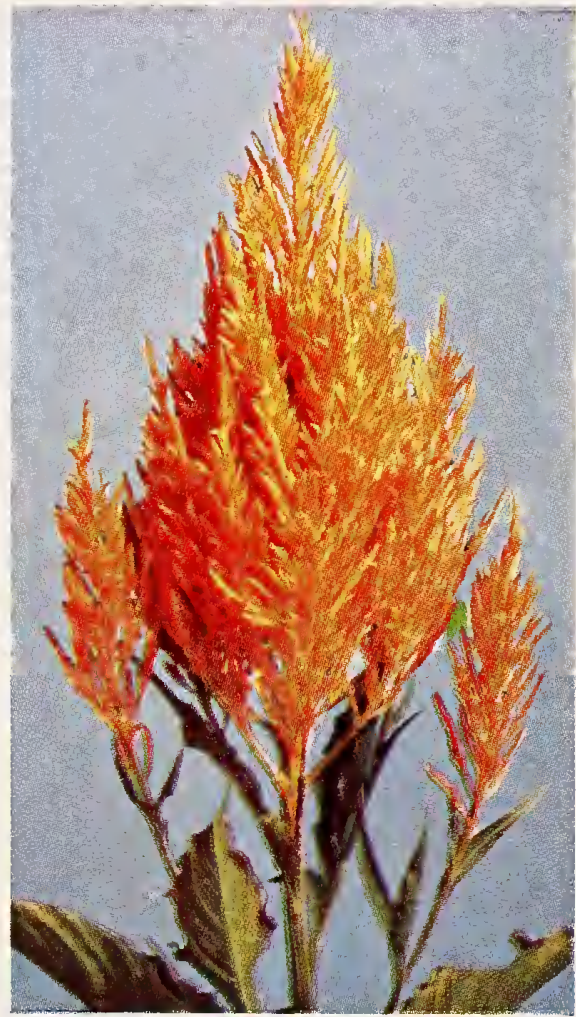

1047 CELOSIA, Golden Fleece

\section{Wortheuhile Nem VEGETABLES BEAN, CHEROKEE WAX}

39 Cherokee Wax is rapidly becoming the favorite garden, market and shipping variety. Its straight slender oval pods are stringless, fiberless and of excellent canning quality. The hardy disease resistant plants are vigorous and highly productive. Probably the most prolific of the wax podded varieties it continues over a long season bearing bright yellow 6 inch pods.

\section{SALAD BOWL LETTUCE}

283 Tender and sweet Salad Bowl forms a pretty rosette of rich green, very decorative leaves which are cut and lobed like the Oakleaf variety but are much more resistant to heat and tip-burn. The plants are more vigorous, faster growing and Iarger, with a handsome appearance. Salad Bowl lettuce is the slowest loose-leaf lettuce to bolt to seed, thus retaining its extremely high quality, sweetness and tenderness over a long period.

For prices see vegetable seed list in the preceding pages.

\section{BUY THEM FROM YOUR LOCAL DEALER}

Grocery and Supply Stores Over the Intermountain West

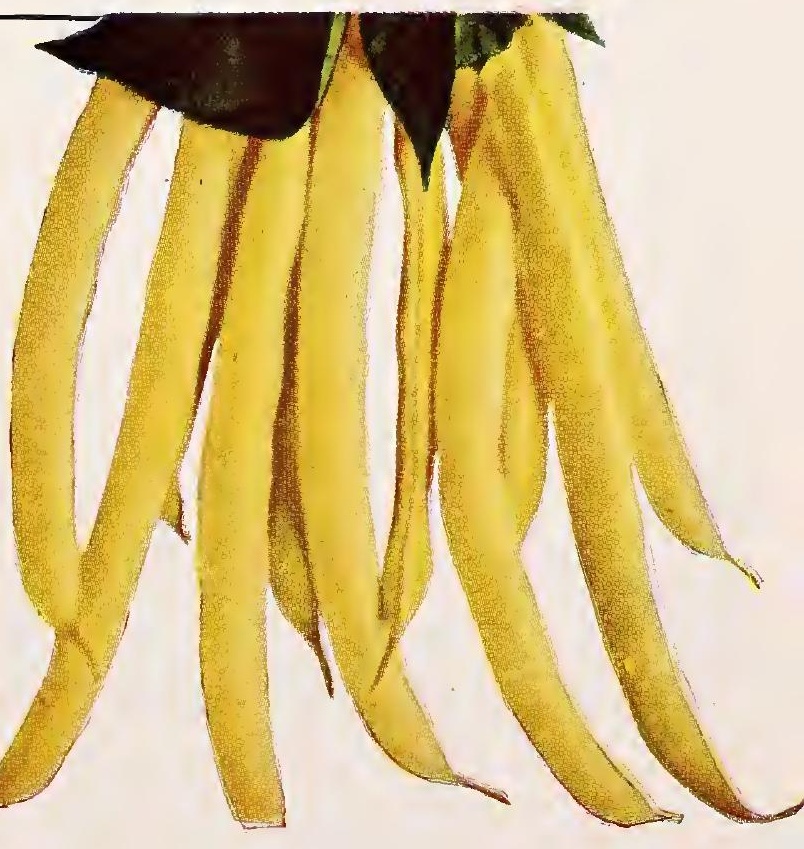




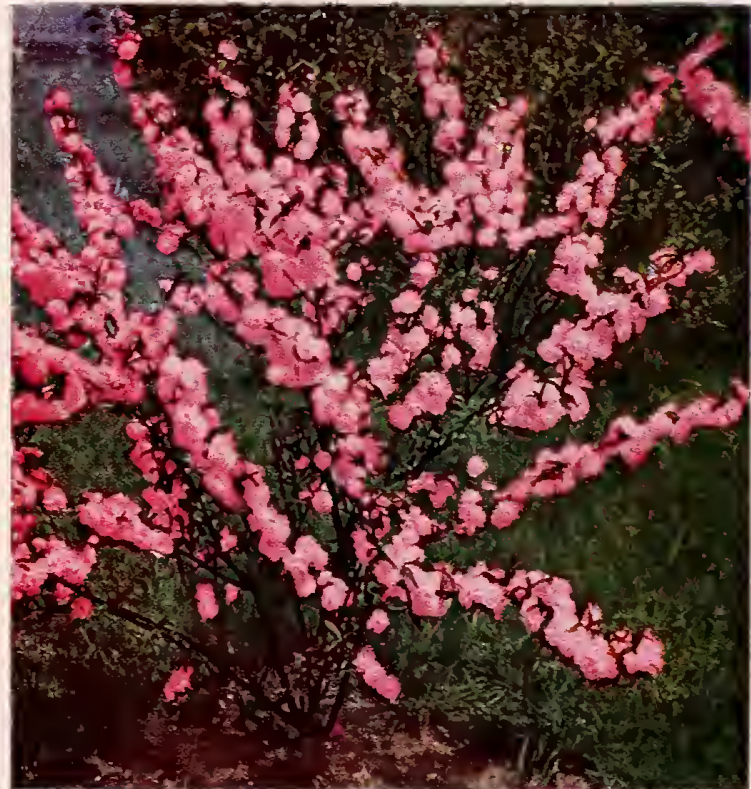

9190 FLOWERING ALMOND

$$
\text { Grows } 4 \text { to } 5 \mathrm{ft} \text {. }
$$

12 to 18-in., 50c each; 10 for 54.30

18 to 24-in., 90c each; 10 for $\$ 8.00$

2 to $3 \mathrm{ft}$., $\$ 1.25$ each

\section{Beautiful}

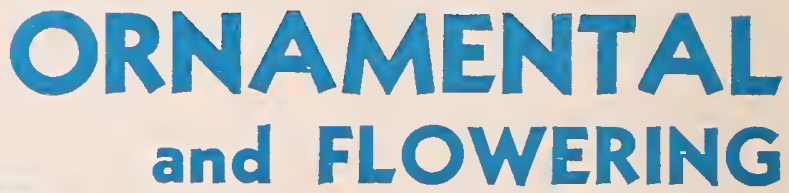

9328 MOCK-ORANGE, Virginalis Grows $8 \mathrm{ft}$. high. 18 to 24 in., 90c each; 10 for $\$ 8.00$

2 to $3 \mathrm{ft}$., $\$ 1.25$ each; 10 for $\$ 11.00$

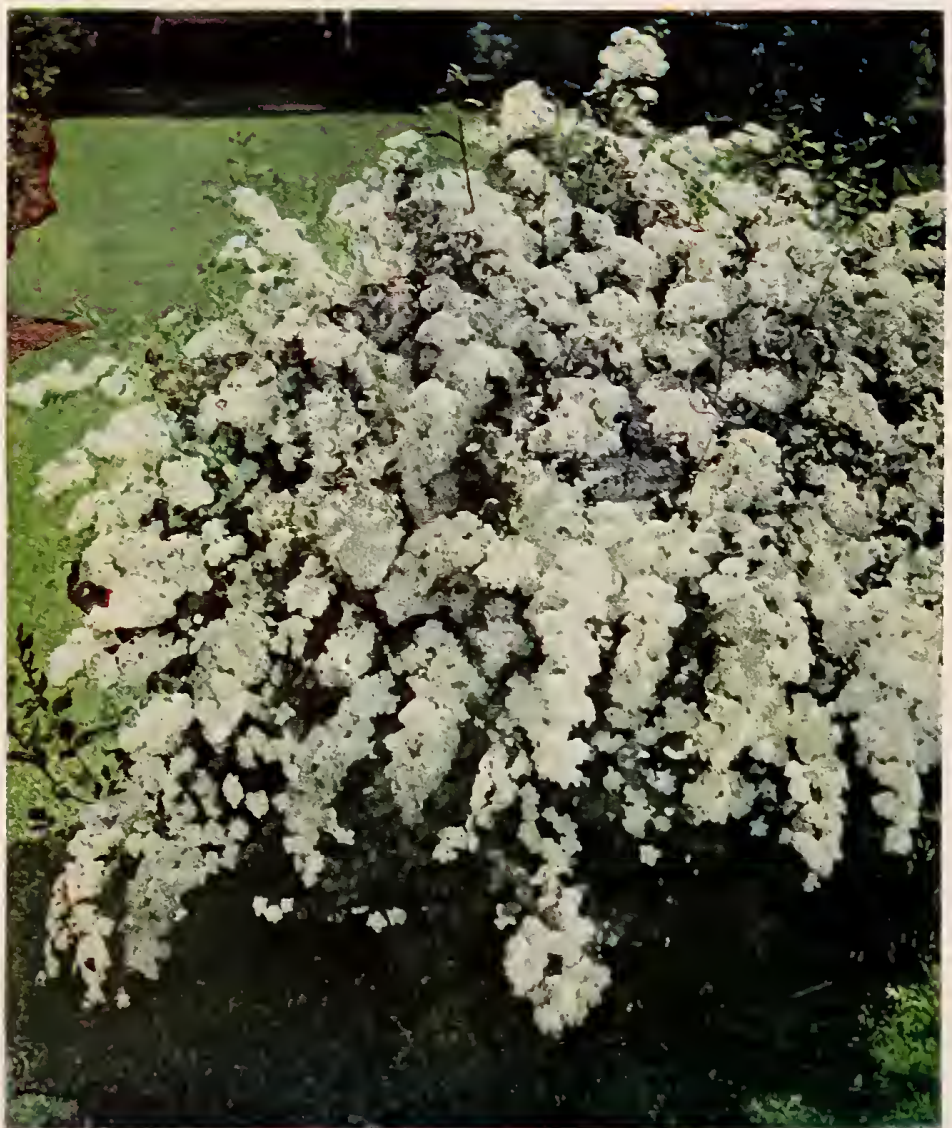

9368 RRIDAL WREATH (Spiraea Vanhouttei) Grows $8 \mathrm{ft}$. high.

12 to 18 in., 50 c each; 10 for $\$ 4.30$ 18 to 24 in., $75 \mathrm{c}$ each; 10 for $\$ 6.50$

2 to $3 \mathrm{ft}$., $\$ 1.25$ each; 10 for $\$ 11.00$

3 to $4 \mathrm{ft}$., $\$ 1.50$ each; 10 for $\$ 13.50$

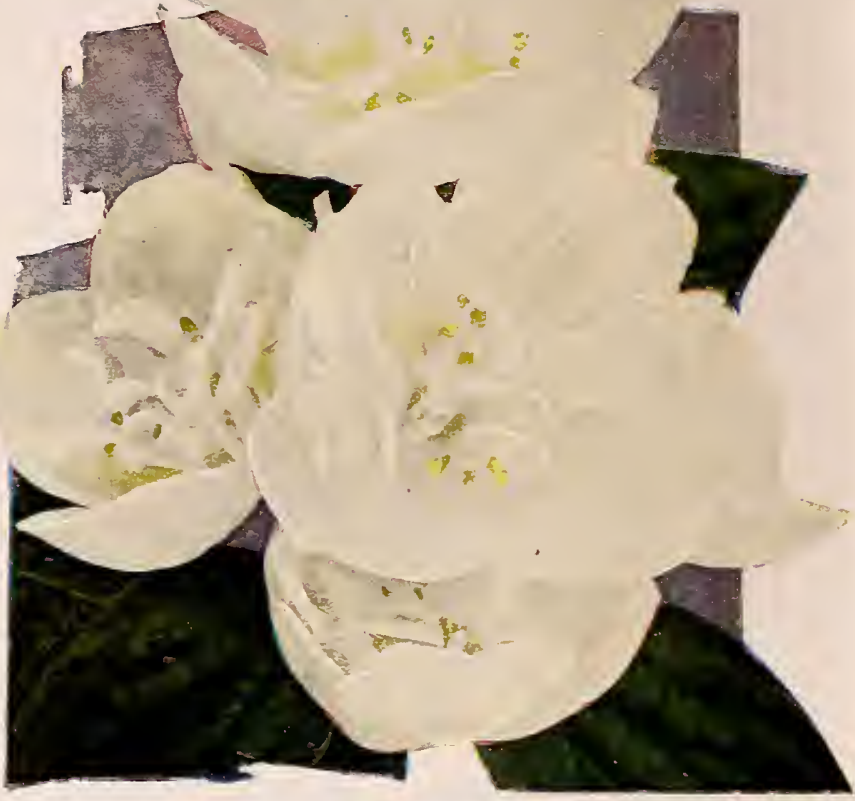

12 to 18 in., 50c each; 10 for $\$ 4.30$

\section{SHRUBS}

\section{HEDGE AND SCREEN SHRUBS}

On this and the opposite page you will find the most adaptable shrubs for informal low hedges or tall boundary screens. Long rows of a single variety are extremely effective.

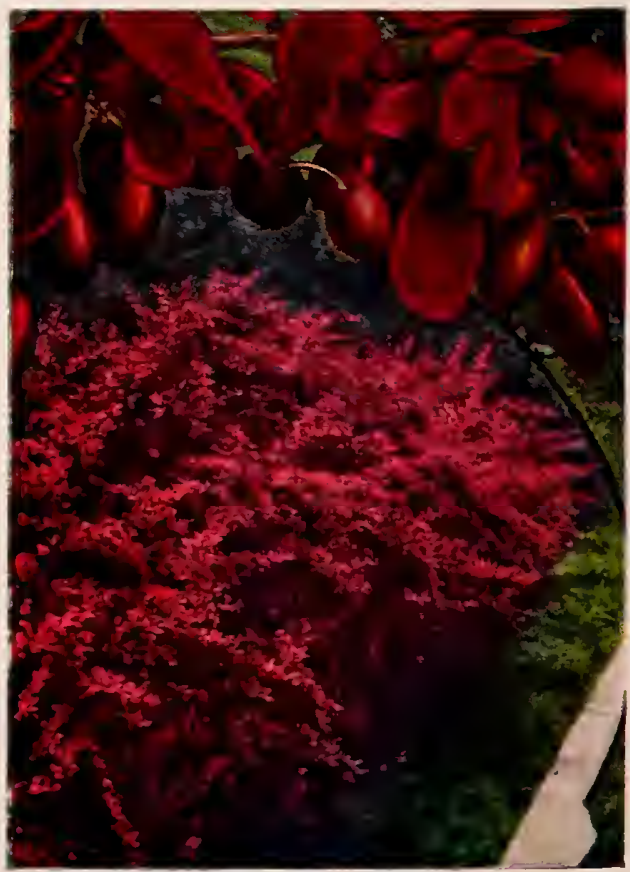

9206 BERBERIS Thunbergi atropurpurea Grows 3 to $4 \mathrm{ft}$. high.

12 to 15 in., 50 c each; 10 for $\$ 4.30$

15 to 18 in. $75 \mathrm{c}$ each; 10 for $\$ 6.70$

18 to 24 in., 90c each; 10 for $\$ 8.00$ 


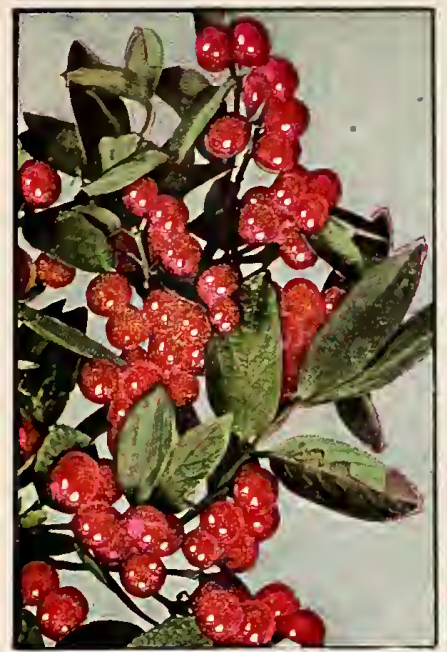

9260 Red HONEYSUCKLE Grows $10 \mathrm{ft}$. high. 12 to $18 \mathrm{im.,} 50 \mathrm{c}$ each; 10 for $\$ 4.30$ 2 to 3 ft., $\$ 1.25$ each; 10 for $\$ 11.00$ 3 to $4 \mathrm{ft}$., $\$ 1.50$ each; 10 for $\$ 13.50$

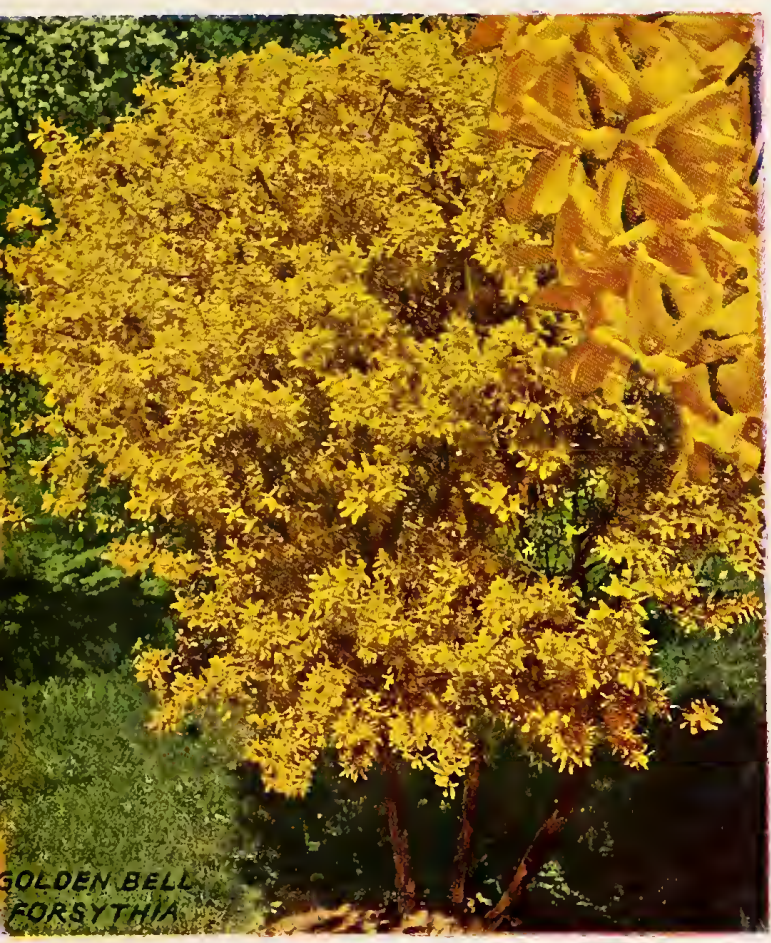
9248 FORSYTHIA spectabilis

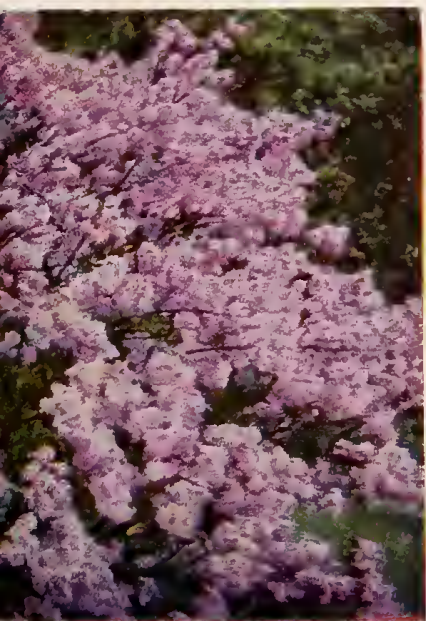

CHINESE LILAC

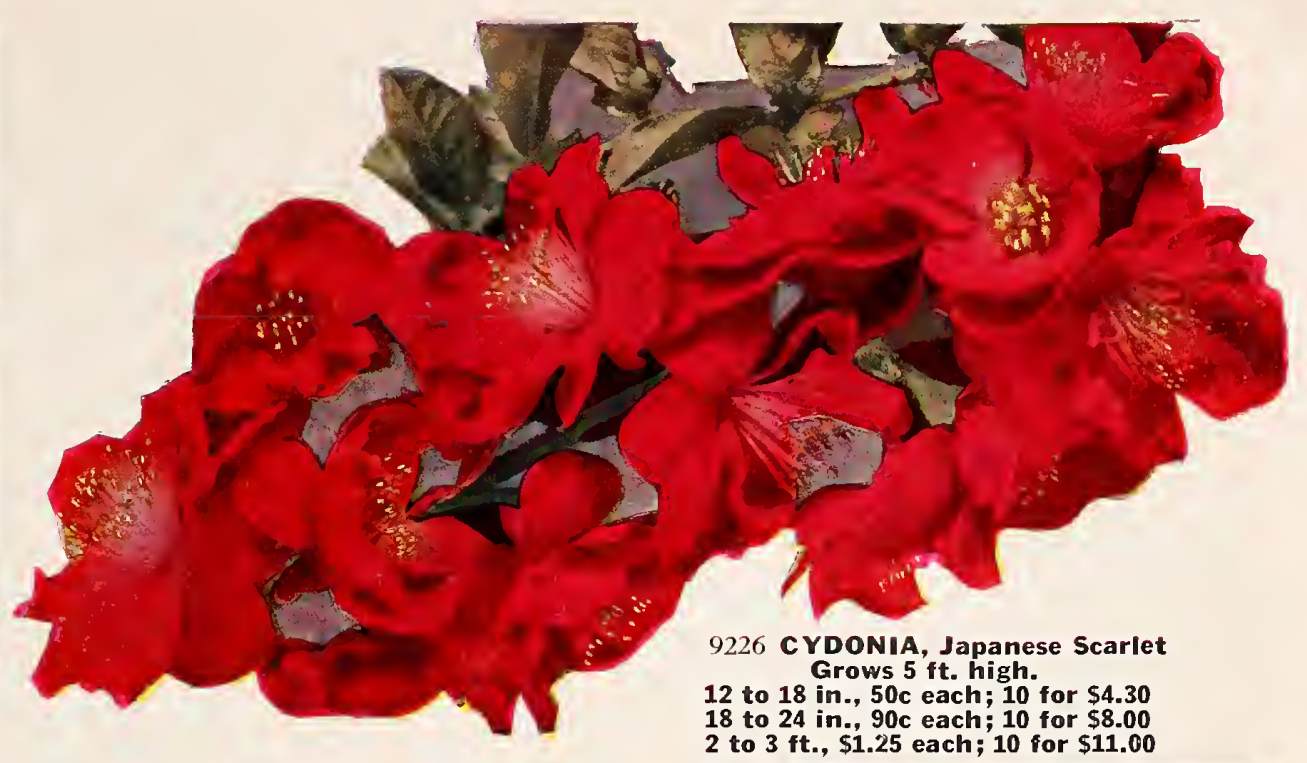

\section{MAIL - ORDER INFORMATION}

Using the total of all shrubs on your order, include with your remittance an additional amount for
packing and postage, according to the following table.

Size $\quad \stackrel{1}{3} \stackrel{3}{10} \stackrel{10}{4}$

15 to 18 in.... \$0 30 \$0 $35 \$ 060$ $\begin{array}{llll}18 \text { to } 24 \text { in...... } & 30 & 45 & 75 \\ 2 \text { to } 3 \mathrm{ft} . . . . & 35 & 60 & 1\end{array}$ 3 to $4 \mathrm{ft} . \ldots . . .645 \quad 45 \quad 150$ Express or motor freight is recommended for large quantities of shrubs.

\section{SPIREA Froebeli}

Grows 4 ft. high.

15 to 18 in., 50 c each; 10 for $\$ 4.30$

18 to 24 in., $\$ 1.00$ each; 10 for $\$ 8.50$

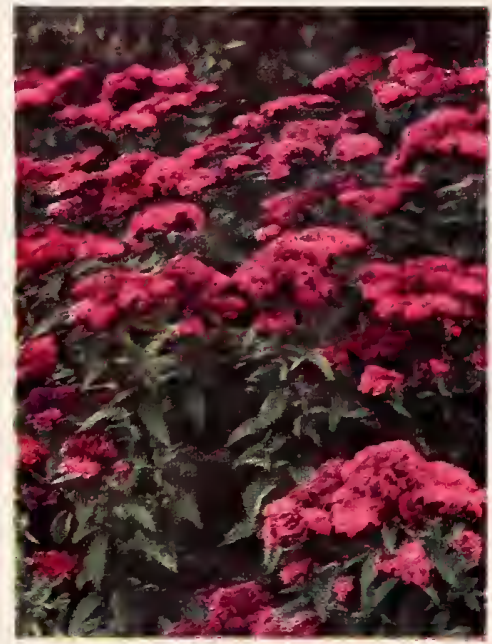

9362 SFIREA Froebeli

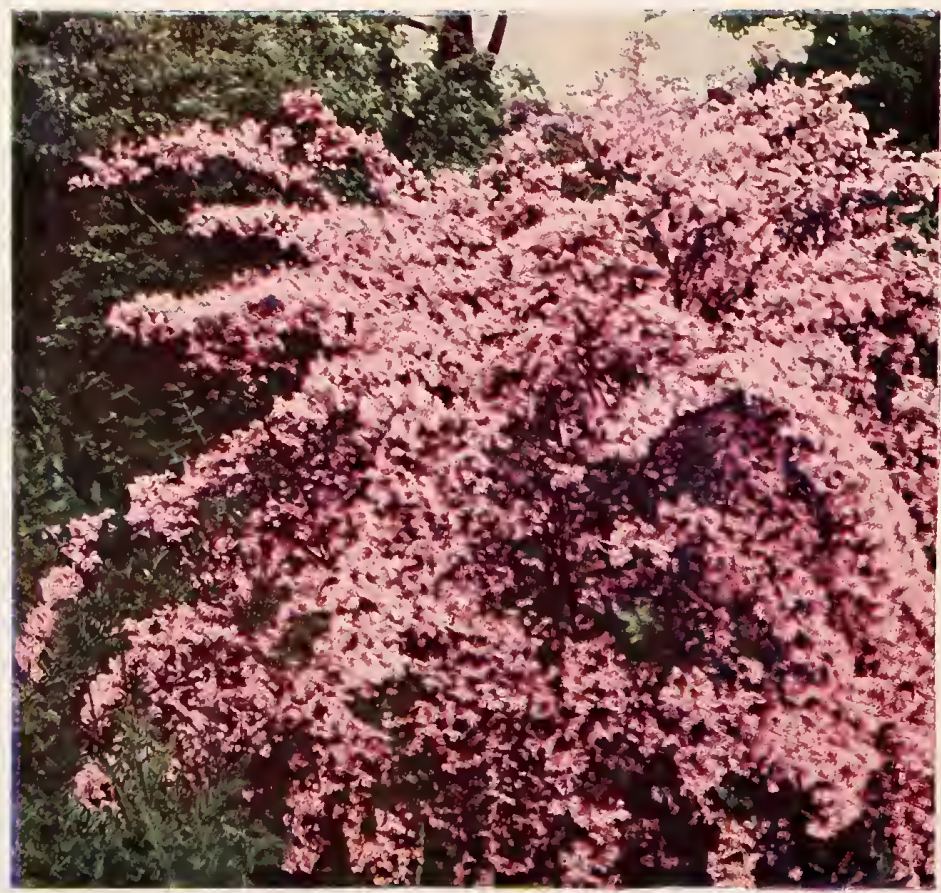

9272 BEAUT Y-BUSH (Kolkwitzia amabilis) Grows $8 \mathrm{ft}$. high

12 to $18 \mathrm{in.}, 50 \mathrm{c}$ each; 10 for $\$ 4.30$

18 to 24 in., $\$ 1.25$ each; 10 for $\$ 11.00$

2 to $3 \mathrm{ft}$., $\$ 1.50$ each; 10 for $\$ 13.50$ 


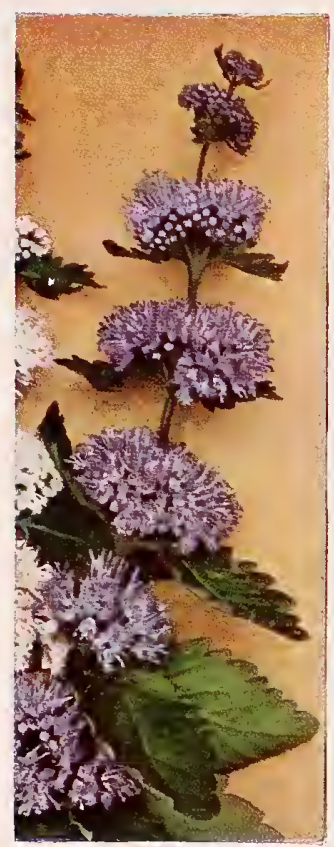
SHRUB

\section{Beautiful ORNAMENTAL and FLOWERING SHRUBS}

\section{Extra Beauty from Color Repetition and Grouping}

Three is a magic number in gardening and landscaping. Three plants of the same variety in a group invariably give a more artistic outline to the planting. To achieve unity and additional charm, use a second group at another point in the border. Repetition of color or texture of foliage in two or more spots in the garden is a landscape principle well worth following.

9213 BLUE MIST

\section{ALTHEA \\ (Hibiscus syriacus) \\ Rose-of-Sharon}

9194 Coelestis. H 10; S 5. Single blue flowers in great quantity. Blooms in Iate summer.

9198 Rubus. $\mathrm{H}$ 10; S 5; Large flowers of deep rose-pink with deeper center.

9196 Snowdrift. H $10 ;$ S 5. Giant single, pure white flowers 4 inches

\section{2 to $3 \mathrm{ft}$, $\$ 1.25$ each; 3 of one variety for $\$ 3.45$}

\section{BERBERIS - Barberry}

9204 Mentorensis. Mentor Barberry. Pat. 99. H 3-5; S 3-4 Semi-evergreen, and best of all the Barberries for foundation, boundary and liedge plantings. It is perfectly hardy, growing uniformly weIl in nearly every situation, even where the summers are extremely hot and dry.

15 to $18 \mathrm{in} ., \$ 1.00$ each; 3 for $\$ 2.70 ; 10$ to $29,70 \mathrm{c} \mathrm{each} ; 30$ to $100,60 \mathrm{c}$ each.

18 to 24 in., $\$ 1.10$ each; 3 for $\$ 3.00 ; 10$ to $29,85 \mathrm{c}$ each; 30 to $100,70 \mathrm{c}$ each.

24 to $30 \mathrm{in}$., $\$ 1.25$ each; 3 for $\$ 3.60 ; 10$ to $29, \$ 1.00$ each; 30 to $100,90 \mathrm{c}$ each.

\section{BLUE MIST SHRUB}

9213 Caryopteris. H 2-3; S 3. Here is a truly fine little shrub that will give you numerous sprays of powder-blue, fringed flowers through August and September. Its foliage is slightly toothed and silvery green in color. Prune it severely in the spring to stimulate abundant new wood for its summer blooming. 2-yr. plants, $\$ 1.25$ each; 3 for $\$ 3.45$.

\section{Buddleia - BUTTERFLY-BUSH}

9211 Royal Red. Pat. 556. H 5-6. From July until frost this beautiful shrub produces large, fully round sprays of rich royal purple. 2-yr. plants, $\$ 1.25$ each; 3 for $\$ 3.45$.

\section{CARAGANA}

9212 Siberian Pea Tree. H 8-10; S 6-8. CommonIy used for backgrounds in the boundary planting. Small clusters of yellow flowers in May. 2 to $3 \mathrm{ft}$., hedge grade, 30c each; 10 to 29 , $25 \mathrm{c}$ each; 30 to $100,20 \mathrm{c}$ each

\section{COTONEASTER}

9220 Acutifolia. H 6-7; S 5-6. Glossy green foliage and black18 to 24 in., $90 \mathrm{c}$ each; 3 for $\$ 2.55$.

2 to $3 \mathrm{ft}$., $\$ 1.25$ each; 3 for $\$ 3.45$.

9224 Divaricata. H 5-6; S 4-5. One of our most graceful and beautiful shrubs. Covered in spring with dainty pink flowers and in fall with an abundance of shiny scarlet berries.

2 to $3 \mathrm{ft}$., bare root, $\$ 2.00$ each; 3 for $\$ 5.70$.

2 to $3 \mathrm{ft}$., in can or $\mathrm{B} \& \mathrm{~B}, \$ 3.00$ each; 3 for $\$ 8.25$.

\section{DEUTZIA}

9234 Slender (Gracilis). H 3; S 3. A dainty small shrub with clusters of pure white flowers in late May. Hardy up to 4500 feet elevation. 15 to 18 in., $\$ 1.50$ each; 3 for $\$ 4.20$.

\section{Cornus - DOGWOOD}

9218 Sibirica. H $6-8$; S 6 . Bright red twigs and branches. 18 to 24 in., 90 c each; 3 for $\$ 2.55$.

2 to $3 \mathrm{ft}$., $\$ 1.25$ each; 3 for $\$ 3.45$.

\section{FLOWERING QUINCE - Cydonia \\ Finest New Forms and Colors}

9229 Charming. H 6 . Large flowers of soft shell-pink, deepening toward the ends of the petals. A neat, orderly shrub which produces a mass of beautiful color early in the spring. Practically thornless. 18 to 24 in., $\$ 3.00$ each; 3 for $\$ 8.25$.

9232 Red Ruffles. Pat. 941 . This new, dazzlingly brilliant red Flowering Quince is the best red introduced to date. The flower petals are so Iarge they overlap, producing an attractive ruffled effect. Erect branches 6 feet taII are almost thornless. 18 to 24 in., $\$ 3.00$ each; 3 for $\$ 8.25$.

9231 Texas Scarlet. Very large flowers over 2 inches across are borne in great profusion over a very long period in early spring. The color is a beautiful watermelon-red. The plant is of low, bushy habit and nearly thornless. 18 to 24 in., \$3.00 each; 3 for $\$ 8.25$.

\section{LONICERA . Bush Honeysuckle}

9266 Morrowi. H 6-8; S 6-8. Most graceful of the Honeysuckles with spreading branches covering the shrub from the ground up. Yellow and white flowers are followed by red berries, which are relished by birds. 2 to $3 \mathrm{ft}$., $\$ 1.25$ each; 3 for $\$ 3.45$. 9258 Tatarica Pink. Tatarian Honeysuckle. H 8-10; S $6-8$ Tall, erect habit. Very hardy; excellent for the back of the shrub border. 2 to $3 \mathrm{ft}$., $\$ 1.25$ each; 3 for $\$ 3.45$.

\section{HYDRANGEA}

9252 Arborescens grandiflora. Hills-of-Snow. H 3; S 3 Sometimes called Summer Snowball because of its large round flower heads, which are two to three times as Iarge as those of the Common Snowball (Viburnum). Thrives in shade or in the sun. Prune severely in early spring to encourage an abundance of new flowering branches. 18 to 24 in., $\$ 1.25$ each; 3 for $\$ 3.45$.

\section{HYPERICUM}

9271 Sungold. Pat. 568. H 2; S 3. A very useful and beautiful addition to the list of dwarf shrubs. It grows into an almost completely oval globe, densely covered with attractive foliage. At the tip of each new twig is produced a cluster of bright golden yellow flowers. Gal. cans, $\$ 2.00$ each; 3 for $\$ 5.70$.

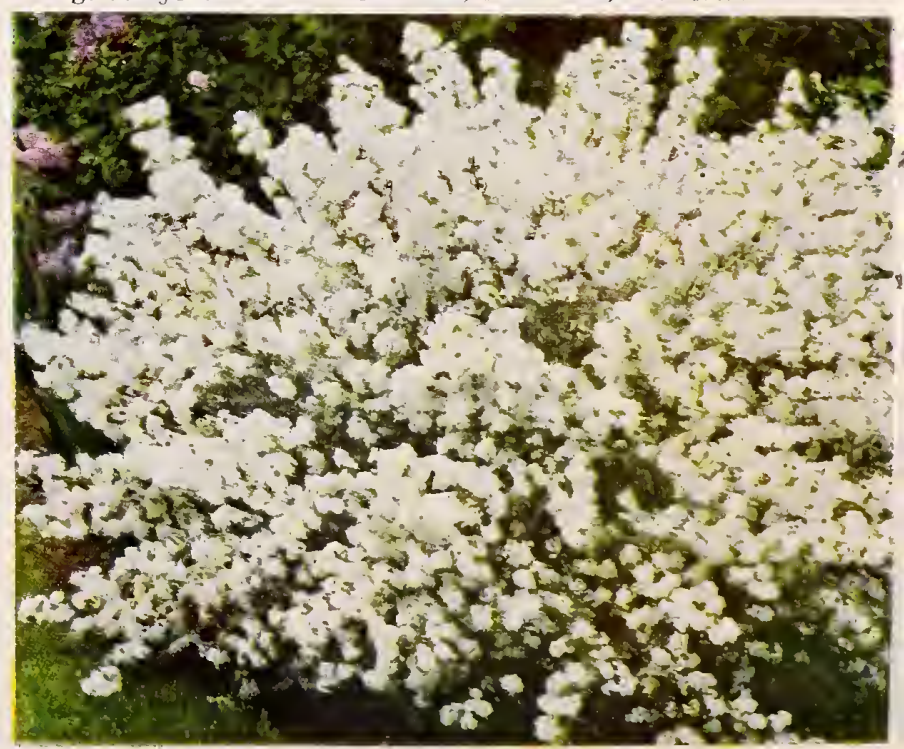

9234 DEUTZIA gracilis 


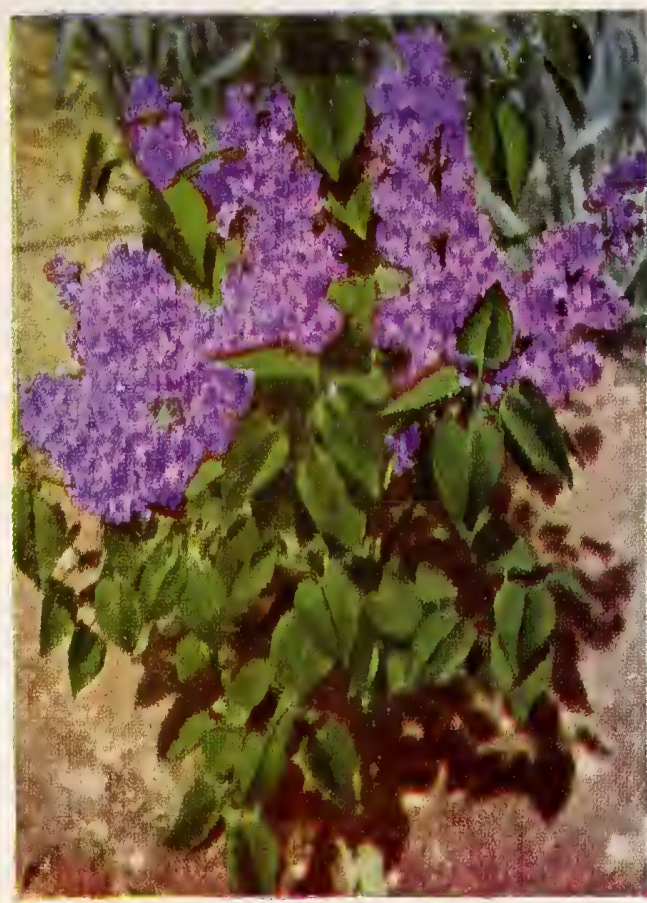

\section{LILAC SPECIES}

9314 Chinese Lilac. See page 11.

9319 Vulgaris. H 10-12. Common Purple Lilae. The oldfashioned favorite.

18 to 24 in., $90 \mathrm{c}$ each; 3 for $\$ 2.55$.

2 to $3 \mathrm{ft}$., $\$ 1.25$ each; 3 for $\$ 3.45$.

\section{Philadelphus - MOCK-ORANGE}

9325 Snowflake. Pat. 538. H 10-12. This new double MockOrange is truly outstanding. Large, sweetly scented flowers of glistening white on a fast-growing, exceptionally hardy plant. 2 to $3 \mathrm{ft}$., $\$ 1.50$ each; 3 for $\$ 4.20$.

\section{Prunus triloba - FLOWERING PLUM}

9678 Double. H 8-10; S 8 . Many rose-pink blooms in early spring cover the arching branches of this fine bush-form flowering Plum. 3 to $4 \mathrm{ft}$., $\$ 1.50$ each; 3 for $\$ 4.20$.

\section{Ligustrum - PRIVET}

9278 Lodense. Dwarf Privet $H$ 2-3. Here is an admirable low foundation plant, which can be used either trimmed or untrimmed. It is excellent for low border hedges. Holds its foliage well into the winter, sometimes until spring.

9 to 12 in. 3 for $\$ 1.20 ; 10$ to $29,35 \mathrm{c}$ each; 30 to 100 , 30c each. 12 to 18 in., 3 for $\$ 1.95 ; 10$ to $29,50 \mathrm{c} \mathrm{each;} 30$ to $100,45 \mathrm{c}$ each. 18 to 24 in., 3 for $\$ 2.25 ; 10$ to $29,65 \mathrm{c}$ each; 30 to $100,60 \mathrm{c}$ each.

9276 Regal (Obtusifolium Regalianum). H 6-8; S 5-6. White flowers in spring. Metallie black berries in the fall. 2 to $3 \mathrm{ft}$., $\$ 1.25$ each; 3 for $\$ 3.45$.

9274 Erggish (Vulgare). H 10-12. The most commonly planted shrub for medium or large hedges. Adaptable everywhere.

18 to 24 in., 3 for $\$ 1.50 ; 10$ to $29,40 \mathrm{c}$ each; 30 to 100 , 35c each. 2 to $3 \mathrm{ft}$., 3 for $\$ 1.80 ; 10$ to $29,45 \mathrm{c}$ each; 30 to $100,40 \mathrm{c}$ each. 3 to $4 \mathrm{ft}$., 3 for $\$ 2.25$; 10 to $29,55 \mathrm{c}$ each; 30 to 100 , 50c each.

\section{RHODOTYPOS}

9338 White Kerria (Kerrioides). H 4-5; S 5. White flowers followed by black fruits that hang on all winter. Very attractive foliage.

18 to 24 in., $\$ 1.25$ each; 3 for $\$ 3.45$.

2 to $3 \mathrm{ft}$., $\$ 1.50$ each; 3 for $\$ 4.20$.

See MAIL ORDER INFORMATION table on page 11 for amount to send for packing and postage.

\section{Sorbaria - FALSE-SPIREA}

9358 Aitchisoni. H 6-8; S 6-8. Bright green, fern-like foliage and upright panicles of white flowers; 12 to 20 inches Iong. 2 to $3 \mathrm{ft}$., $\$ 1.25$ each; 3 for $\$ 3.45$.

\section{SPIRAEA}

9360 Arguta. H 5; S 5. Sprays of pure white flowers in early April. Fern-like foliage is attractive all summer. 18 to 24 in. $\$ 1.00$ each; 3 for $\$ 2.70$.

9364 Prunifolia. Double Bridal Wreath. H 6; S 6. An upright shrub with double white flowers. 2 to $3 \mathrm{ft}$., $\$ 1.50$ each; 3 fo $\$ 4.20$

\section{SUMAC - Rhus}

9342 Glabra. Smootl Sumac. H 6-8; S 3-4. A new cutleaf variety with a fine display of fruit. 3 to $4 \mathrm{ft} ., \$ 1.25$ each; 3 for $\$ 3.45$.

\section{SYMPHORICARPOS}

9372 Chenaulti. H 4-5; S 5. Dainty foliage and red fruit.

9374 Snowberry (Racemosus). H 4-5; S 4. White fruit. Either of above, 2 to $3 \mathrm{ft}$., $\$ 1.25$ each; 3 for $\$ 3.45$.

\section{TAMARIX}

9378 Hispida. H 15; S 6. Fern-like foliage. Soft pink flowers in sprays, produced in early spring and again in July. Prune branches to the ground when planting.

2 to $3 \mathrm{ft}$., $\$ 1.25$ each; 3 for $\$ 3.45$.

3 to $4 \mathrm{ft}$., $\$ 1.50$ each; 3 for $\$ 4.20$.

\section{VIBURNUM}

9384 Americanum. Cranberry-shrub. H 10-12; S 10. Large panicles of white flowers followed by bright scarlet fruits. 18 to 24 in., $\$ 1.25$ each; 3 for $\$ 3.45$.

9388 Opulus sterile. Common Snowball. H 8-10; S 8-10. Has long been a favorite shrub in every type of garden. Its balllike, pure white flowers are borne in late May. 18 to 24 in., $\$ 1.25$ each; 3 for $\$ 3.45$. 2 to $3 \mathrm{ft}$., $\$ 1.50$ each; 3 for $\$ 4.20$.

\section{WEIGELA}

9396 Bristol Ruby. Pat. 492. H 6; S 5. Hardiest and most vigorous of all Weigelas, with a most pleasing habit of growth and color of flower-ruby-red shading to garnet-crimson. June. 2 to $3 \mathrm{ft}$., $\$ 1.50$ each; 3 for $\$ 4.20$. 


\section{ROSE GARDEN}

\section{CRIMSON AND SCARLET}

8806 Christopher Stone. A glowing, velvety scarlet-crimson. Mildly fragrant.

8810 Etolle de Hollande. Large, semi-double flowers of richest red with pleasant fragrance.

8812 Grenoble. Glorious deep crimson-red.

8814 McGredy's Scarlet. Dark rose-scarlet flowers of Iarge size.

8820 Poinsettia. Glowing fire-red. Long, pointed buds; vigorous.

\section{PINK}

8900 Countess Vandal. One of the most widely planted Roses.

Long, tapered buds of salmon-pink, shaded copper and gold. 2 to $2 \frac{1}{2}$ feet tall.

8864 Dainty Bess. Large, single, rose-pink blooms with winered stamens.

8872 Editor McFarland. Perfectly formed, fresh deep pink.

8874 Picture. Warm pink with undertones of salmon. A dainty flower of exquisite form.

8876 Pink Dawn. Large, deep rose-colored buds opening to pink with shades of dawn-gray touched with orange. Fragrant. 8878 The Doctor. Long, pointed buds and enormous blooms of silvery pink. Fragrant.

\section{WHITE AND BLUSH-WHITE}

8886 McGredy's Ivory. Large, well shaped, creamy white, fragrant.

8888 Mme. Jules Bouche. Medium-sized, gracefully formed, white flowers, with a delicate pink flush in the center

8887 Snowbird. Long flaring white buds open to medium-sized, fully double blooms. Very floriferous.

\section{YELLOW}

8852 Golden Rapture. Beautiful long-stemmed yellow buds and long-Iasting fragrant blooms.

8854 Joanna Hill. Buds of orange-yellow opening to double flowers of orange and cream.

8856 Mrs. E. P. Thom. The beautifully formed buds develop into perfect blooms of rich yellow with delicate fragrance.

8857 Mrs. P. S. du Pont. A deep golden Rose with extra fine buds and good blooming habit.

8858 Soeur Therese. Fine long, pointed, yellow buds with scarlet veining. Fragrant.

\section{COPPER-SALMON}

8832 Autumn. Rich burnt-orange, yellow and red.

8836 Duquesa de Penaranda. The very shapely buds are an unusual shade of apricot-orange, opening slightly lighter.

8844 Mme. Joseph Perraud. Novel nasturtium-orange, flushed shell-pink.

8839 Mrs. Sam McGredy. Very rich copper-orange, heavily flushed with Lincoln red. Fragrant.

8846 President Herbert Hoover. Striking maroon-orange, gold and cerise-pink.

8848 Talisman. Sensational rich golden apricot, stained copper.

Prices on all Roses on this page, $\$ 1.25$ each; 3 or more of one kind, $\$ 1.05$ each.

\section{MAIL ORDER INFORMATION}

Using the total of all Rose plants on your order, include with your remittance an additional amount for packing and postage according to the following schedule.

For 1 or 2 Roses, send $25 c$

For 3 Roses, send $35 \mathrm{c}$

For 5 Roses, send $45 \mathrm{c}$

For 10 Roses, send $60 \mathrm{c}$

For 25 Roses, send $\$ 1.00$

No order will be accepted for less than $\$ 3.00$ (total all merchandise) unless accompanied by $25 \mathrm{c}$ additional service charge.

See Mail Order Information Table for amount to send for packing and postage.

GOLDEN

RAPTURE

\section{SIX ROSE} GARDEN FAVORITES

\section{Collection No. 9135}

One each of Etoile de Hollande, Autumn, Golden Rapture, Countess Vandal, Pink Dawn, McGredy's Ivory.

(\$7.50 Value)

ONLY \$6.00

If by mail, include $45 c$ additional for packing and postage.

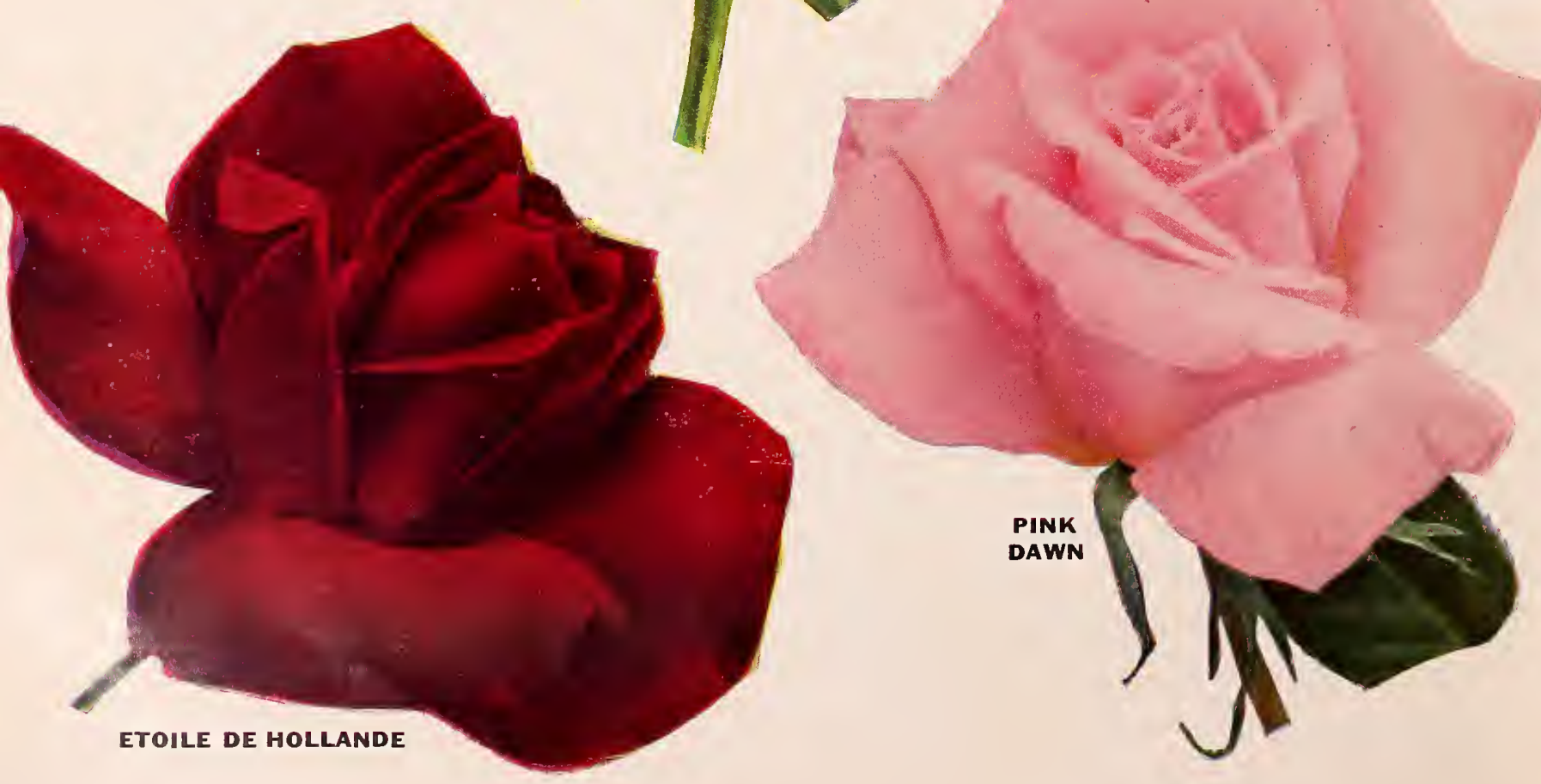




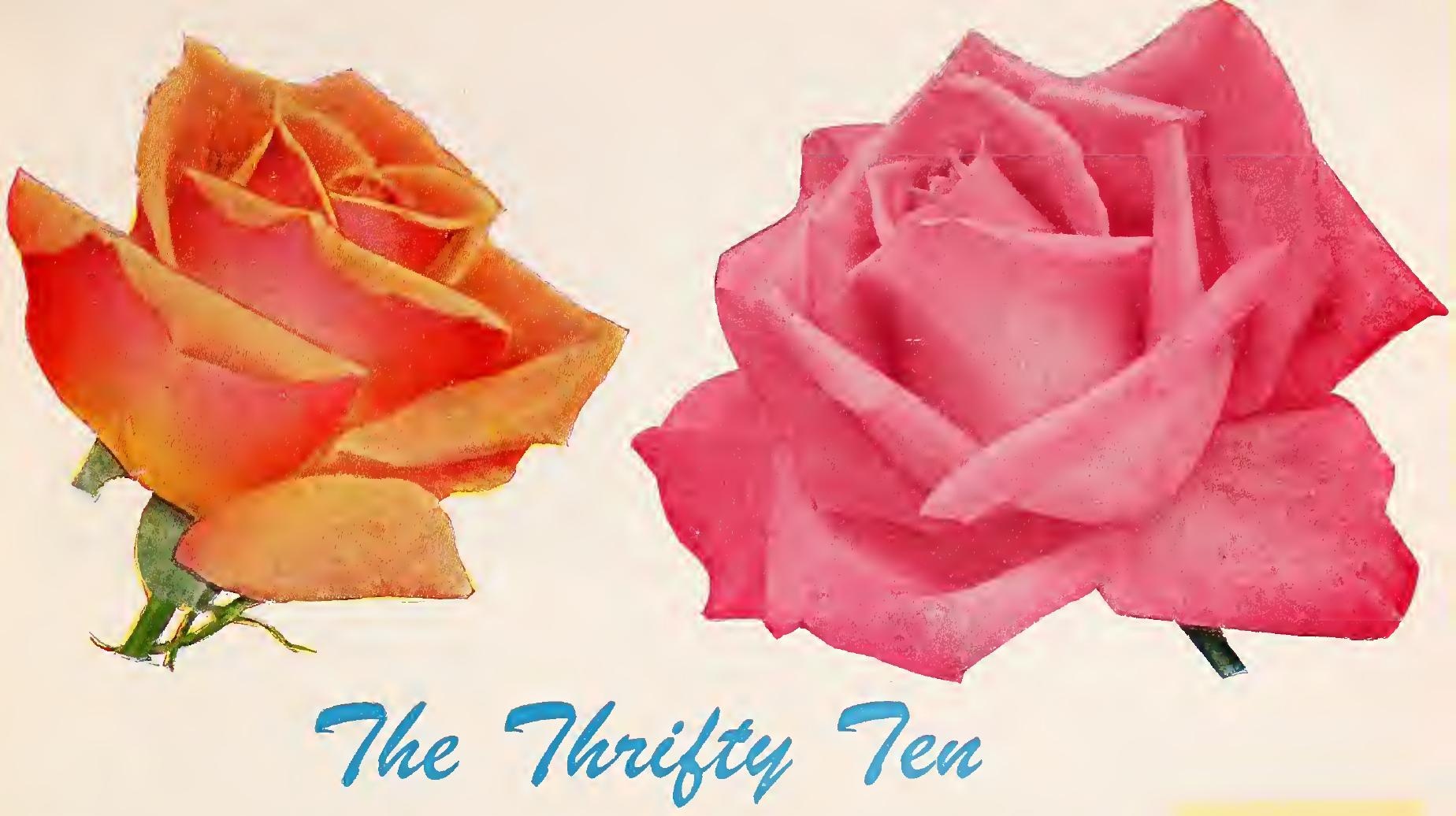

Here is a real Rose bargain which will make it easy for you to start a new Rose garden or expand an established one.

Ten popular named Roses of our selection, one each of the following colors and shades:
Crimson Scarlet Gold
Cream
Salmon

\section{ROSE COLLECTION No. 9133}

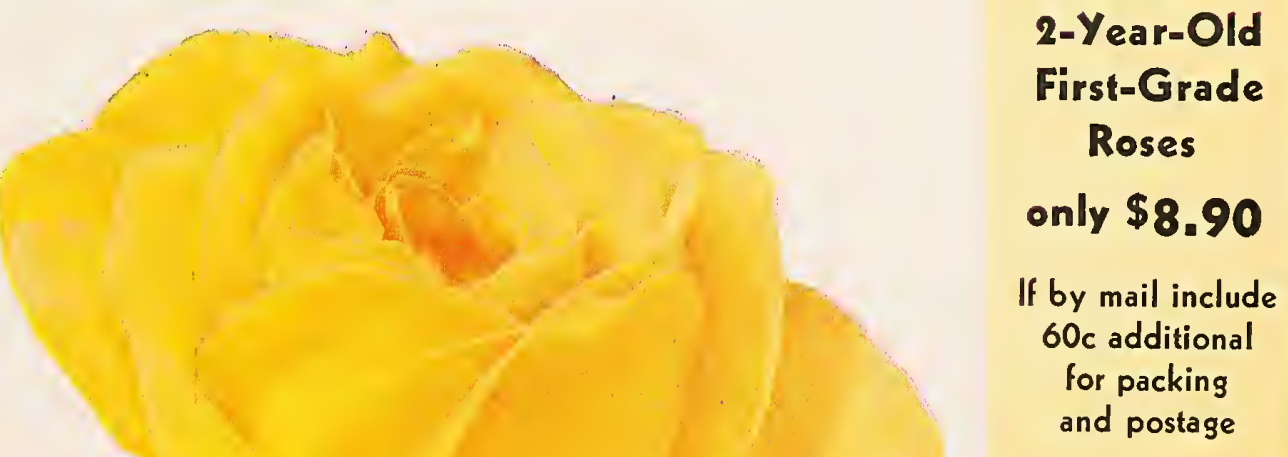

All 10

2-Year-Old -

If by mail include $60 \mathrm{c}$ additional for packing and postage 


\section{Novelty Rases \\ See page 14 for amount \\ to send for postage and packing.}

8901 Capistrano. Pat. 922. AARS. The Iong, beautifully formed buds are clear rich rose-pink, expanding to Iarge blooms which hold their color exceptionally well. Tall, sturdy plants with long straight stems. $\$ 2.25$ each; 3 or more, $\$ 2.00$ each.

8898 Charlotte Armstrong. Pat. 455. AARS. Long-stemmed flowers are spectrum-red in the cooler seasons and cerise-red during the summer. They open slowly and retain their beauty a long time. $\$ 2.00$ each; 3 or more, $\$ 1.75$ each.

8902 Crimson Glory. Its large, shapely, fragrant buds open into full double blooms of deep vivid crimson. A continuous bloomer and an outstanding Rose in every respect. $\$ 1.75$ each; 3 or more, $\$ 1.55$ each.

8908 Eclipse. Pat. 172. One of the all-time great Roses, and one which grows well in all localities. Long, streamlined buds of pale yellow. 2 to $21 / 2$ feet tall. $\$ 1.75$ each; 3 or more, $\$ 1.55$ each

8909 Forty-niner. Pat. 792. AARS. Beautifully formed buds of vividIy contrasting colors. Inside the petals are a glowing Oriental red, while outside they are pure chrome-yellow. The full double blooms are long lasting and mildly fragrant. \$2.25 each; 3 or more, \$2.00 each.

8912 Fred Howard. Pat. 1006. All-America Award winner for 1952. Large, rich yellow buds open to full, high-centered flowers of light yellow-buff edged with pink. \$2.50 each; 3 or more, $\$ 2.20$ each.

8915 Helen Traubel. Pat. 1028. AII-America Award winner for 1952. This new introduction has long buds and large full flowers of light sparkling pink. Under varying weather conditions it develops shades of rich luminous apricot which make a beautiful combination. The bush is large and vigorous, producing an almost constant array of lovely long-stemmed blooms. $\$ 2.75$ each; 3 or more, $\$ 2.40$ each.

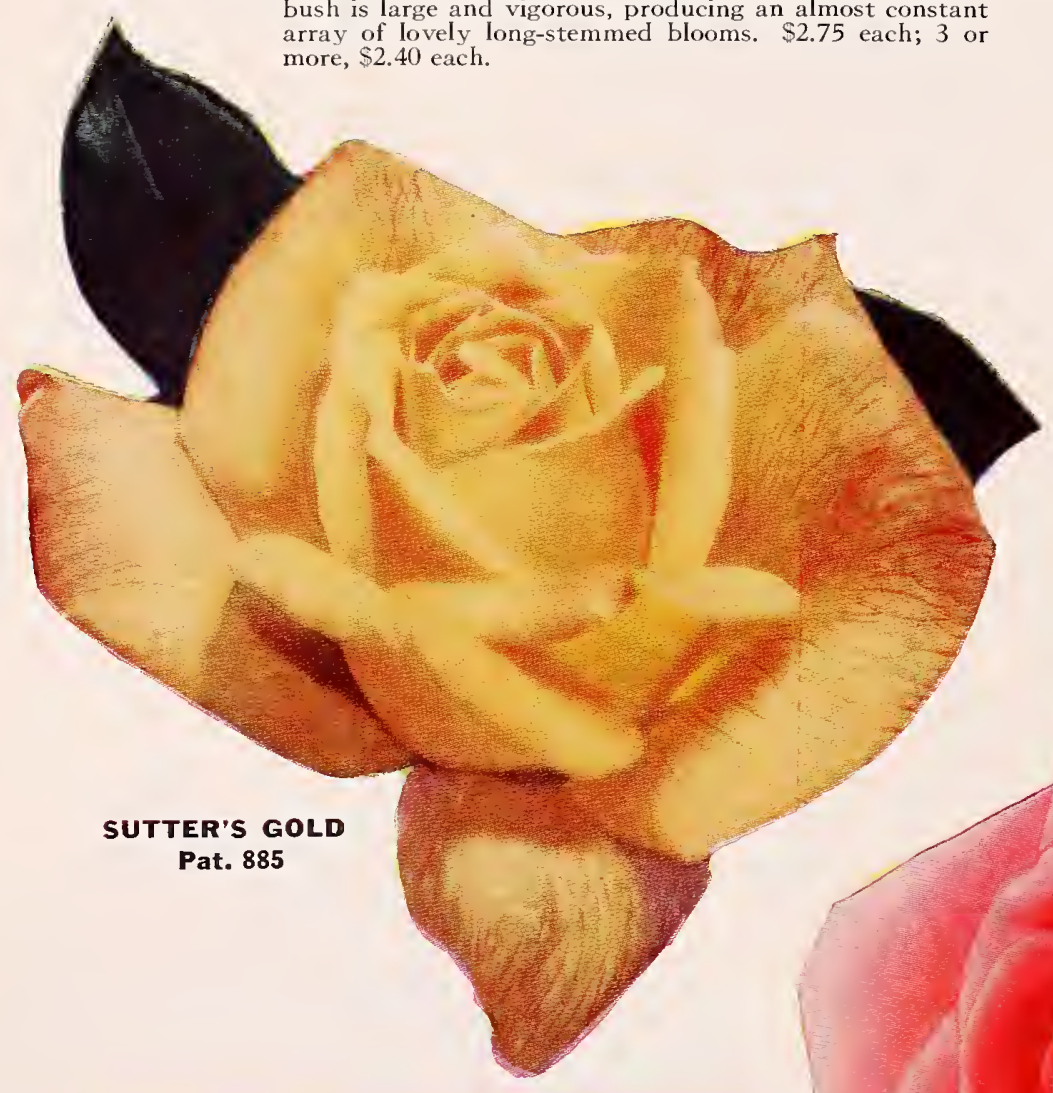

THREE SUPERB ROSES Collection Mo. 9141

Each of these is a large grower, with excellent foliage and wonderful blooms.

\section{Katherine T. Marshall}

Mme. Henri Guillot Sutter's Gold

ONE OF EACH

$(\$ 5.75$ Value $)$

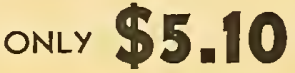

If by mail, include $35 \mathrm{c}$ additional for packing and postage.

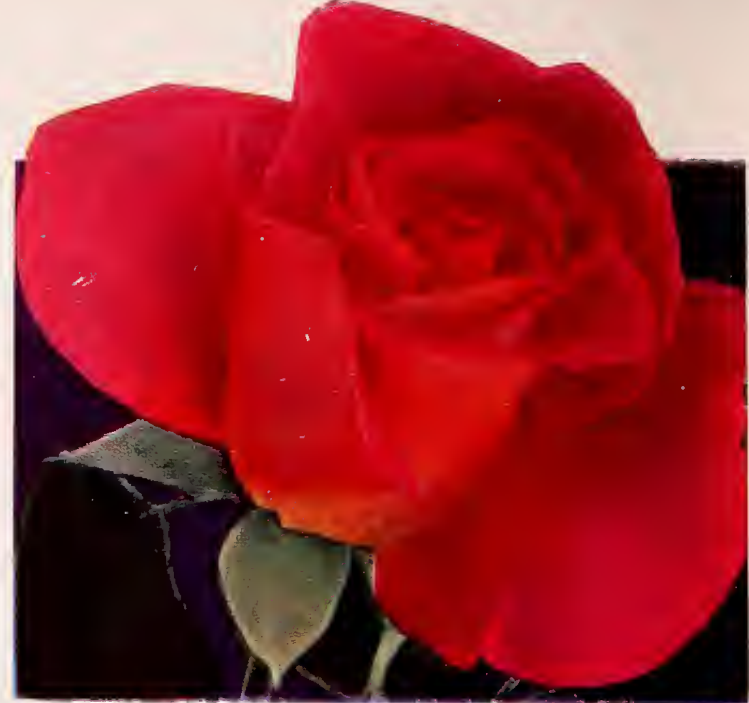

MME. heNRI GUILLOT. Pat. 337

\section{The World's Newest Red Rose}

\author{
1953 ALL-AMERICA WINNER
}

\section{CHRYSLER IMPERIAL}

\section{See front cover.}

8903 A descendant of the famous Mirandy and Charlotte Armstrong this beautiful crimson Hybrid Tea just couldn't help being a winner. Chrysler Imperial so well combines the fine growth and blooming habits of both its parents that it is sure to reach the very peak of popularity.

With typical "red Rose" appeal, this new beauty produces big $41 / 2$ to 5 -inch, high-centered blooms having up to 50 heavily substanced, long-lasting petals. This, together with its unusual beauty of form in bud and open bloom, makes Chrysler Imperial one of the most promising exhibition Roses.

The plant is vigorous, compact and symmetrical, with stems sturdy and erect. Flowers abundantly fragrant. Pat. applied for. $\$ 3.00$ each; 3 or more, $\$ 2.60$ each. 


\section{Novelty Rases}

8918 Katherine T. Marshall. Pat. 607. AARS. One of America's finest Roses. Vigorous, robust plants with extra sturdy stems. The big, heavy-textured petals of warm, clear pink form magnificent buds and half-open blooms. Richly fragrant. $\$ 1.75$ each; 3 or more, $\$ 1.55$ each.

8922 Lowell Thomas. Pat. 595. AARS. One of the best lemon-yellow Roses. The 25-petaled blooms open from beautiful buds with high-cupped centers, the petals rolling outward to make magnificent, glowing flowers over 4 inches across when fully open. Plants sturdily upright, with good foliage. $\$ 2.00$ each; 3 or more $\$ 1.75$ each

8934 Mirandy. Pat. 632. AARS. A plant of tall, vigorous habit, producing large, double blooms of rich maroon-red with penetrating fragrance. $\$ 2.00$ each; 3 or more, $\$ 1.75$ each.

8936 Mission Bells. Pat. 923. AARS. Pointed, well-shaped buds of deep glowing salmon-pink open to fuIl, high-centered flowers of clear shrimp-pink, with rich fragrance. The strong, well-branched plants are nearly always in bloom. \$2.25 each; 3 or more, $\$ 2.00$ each

8939 Mme. Henri Guillot. Pat. 337. A large, cupped bloom of coral-red. Glossy foliage. $\$ 1.75$ each; 3 or more, $\$ 1.55$ each.

8941 New Yorker. Pat. 823. Large blooms of rich velvety scarlet with stimulating fragrance. The plants are bushy and vigorous, with lots of flowers. $\$ 2.00$ each; 3 or more, $\$ 1.75$ each.

8940 Nocturne. Pat. 713. AARS. The buds of this dark red variety are long and gracefully shaped, carried singly on a stem. As it opens the flower is dark red with maroon shadings. The plant is strong growing, bushy, upright. $\$ 2.00$ each; 3 or more, $\$ 1.75$ each.

8946 Peace. Pat. 591. AARS. Peace is truly a superior Rose both in flower and in the hardy, vigorous, disease-resistant plant. The double, high-centered blooms open from buds of golden yellow, etched with pink, which change to pale gold and finally to iridescent cream. $\$ 2.50$ each; 3 or more, $\$ 2.20$ each.

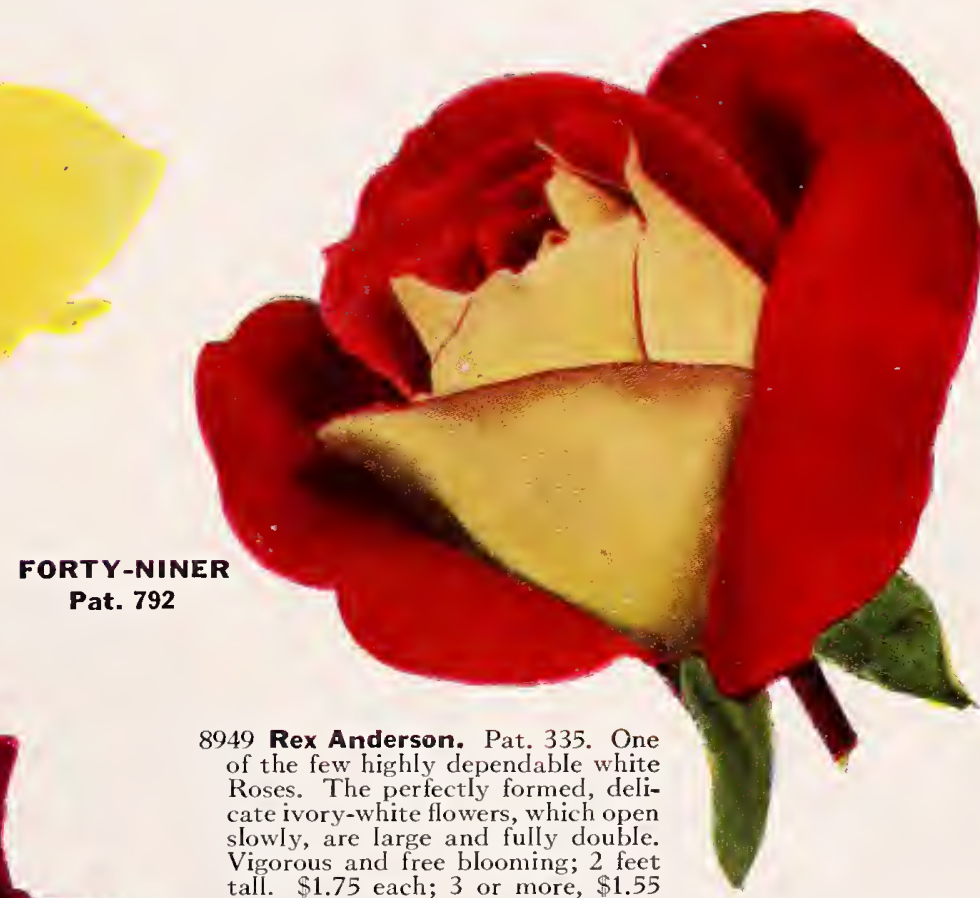
tall $\$ 1.75$ each; 3 or more, $\$ 1.55$ each.

8947 Rubaiyat. Pat. 758. AARS. The gorgeous tapered buds of rich cerise-red, deeper as the flower expands, are delicately fragrant. A vigorous grower and persistent bloomer. \$1.75 each; 3 or more, $\$ 1.55$ each.

8951 San Fernando. Pat. 785. AARS. A perfectly shaped, streamlined bud of intensely brilliant red and a rich heady perfume are the outstanding characteristics of this All-America Selection. The petals of glowing currant-red, changing to bright scarlet, have a firm heavy texture that gives them a longlasting quality. $\$ 1.75$ each; 3 or more, $\$ 1.55$ each.

\section{THE STANDBY THREE}

\section{Collection No. 9144}

One each of Crimson Glory, Eclipse, Forty-niner

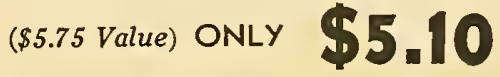




\section{Nouelty Rases}

8956 Show Girl. Pat. 646. A strong, upright grower, branching freely and producing a constant supply of amazing long, intense pink buds. Pleasing fragrance. $\$ 1.75$ each; 3 or more, $\$ 1.55$ each.

8957 Signora. Pat. 201. Buds of warm brownish orange open to lighter mandarin and salmon. Signora is a tall, vigorous grower with glossy, dark green foliage, in many respects superior to the well-known President Herbert Hoover. Very fragrant. $2 \frac{1}{2}$ to 3 feet taII. $\$ 1.75$ each; 3 or more, $\$ 1.55$ each.

8955 Sutter's Gold. Pat. 885. AARS. Exquisite long-pointed, bright yellow buds richly shaded with orange and red. Its heavy texture and fragrance are unequaled in any other yellow Rose. The plant is vigorous, sturdy, erect and covered with big glossy leaves, $\$ 2.25$ each; 3 or more, $\$ 2.00$ each.

8960 Taffeta. Pat. 716. AARS. With each change of the season this vigorous, upright-growing Rose displays an exciting new combination of colors. Sometimes rose-pink, salmon or apricot, its predominant color is rich carmine-rose in the bud, changing to begonia-rose in the open flower. $\$ 1.75$ each; 3 or more, $\$ 1.55$ each.

8959 Tallyho. Pat. 828. A unique and beautiful blend. The inside of the petals is a delightful shade of pink and the outside rose-red, making a blend of unusual warmth. A vigorous grower producing plenty of long-stemmed flowers of wonderful substance and spicy fragrance. $\$ 2.00$ each; 3 or more, $\$ 1.75$ each.

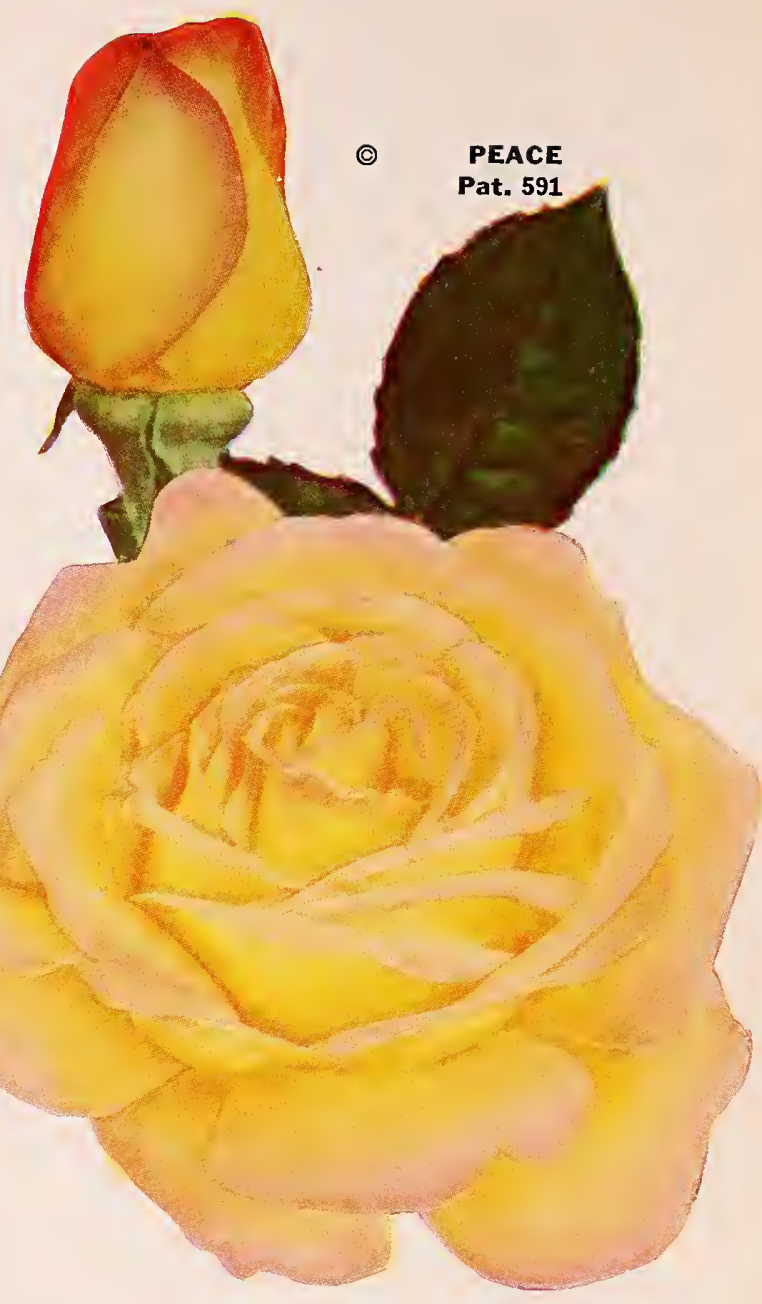

\section{Red, Pink and Cream Rose Collection No. 9138}

One each of these WorldFamous Roses.

Peace

Show Girl

Mirandy

(\$6.25 Value)

\section{Only $\$ 5.50$}

If by mail, include $35 \mathrm{c}$ additional for packing and postage. 


\section{Haribunda Rases}

These are extra hardy, everblooming varieties specially bred for mass planting. They are not only permanent but are colorful and beautiful. Plant about 16 inches apart each way.

9008 Carrousel. Pat. 1066. An outstanding new Floribunda from the standpoint of vigorous, healthy growth and hardiness. Its sparkling red color and amazing kecping quality have won it a high rating from The American Rose Society. $\$ 2.00$ cach; 3 or more, $\$ 1.75$ each.

9026 Cecile Brunner. The "Sweetheart" Rose. Perfect for boutonnieres. Dainty seashell-pink; delightfully fragrant. 18 to 24 inches tall. 2 yr., No. 1 . $\$ 1.25$ each; 3 to $9, \$ 1.05$ each; 10 to $29, \$ 1.00$ each. 9002 Chatter. Pat. 739. Renarkably long-lasting clusters of bright crimson flowers $2 \frac{1}{2}$ to 3 inches across. The petals are frrm textured, holding their color for several days. Almost continuously in bloom. $\$ 1.50$ each; 3 to $9, \$ 1.30$ each; 10 to $29, \$ 1.25$ each.

9009 Donald Prior. Pat. 377. A vigorous grower, generous in its production of vivid deep red blooms. $21 / 2$ to 3 feet tall. $\$ 1.50$ each; 3 to $9, \$ 1.30$ each; 10 or more, $\$ 1.25$ each.

9012 Else Poulsen. Lasting, brilliant, two-toned rose-pink. Semido'sble; sweetly scented. $2 \frac{1}{2}$ to 3 feet tall. 2 yr., No. 2. $80 \mathrm{c}$ each; 3 to $9,75 \mathrm{c}$ each; 10 to $29,70 \mathrm{c}$ each

9013 Eutin. Extremely large clusters of glowing, deep red blooms. Large, mildew-resistant foliage. Vigorous. $80 \mathrm{c}$ each; 3 to $9,75 \mathrm{c}$ each; 10 to $29,70 \mathrm{c}$ each.

9005 Fashion. Pat. 789. Peach-colored All-America Floribunda. $\$ 2.00$ each; 3 to $9, \$ 1.75$ each; 10 to $29, \$ 1.70$ each.

9014 Floradora. Very double, orange-scarlet flowers in clusters. Upright grower, 3 feet tall. $80 \mathrm{c}$ each; 3 to $9,75 \mathrm{c}$ each; 10 to 29 , $70 \mathrm{c}$ each.

9003 Folkestone. An exceptionally worthwhile Floribunda. Its large, crimson scarlet, semi-double blooms are borne in broad clusters. Plants are vigorous and bushy, with dark green foliage. 2 yr., No. 2. 80 c each; 3 to 9, 75c each; 10 to 29,70 c each.

9015 Goldilocks. Pat. 672. Clusters of golden yellow flowers are borne almost continuously on compact, 18 -inch bushes. $\$ 1.50$ each; 3 to $9, \$ 1.30$ each; 10 to $29, \$ 1.25$ each.

9018 Improved Lafayette. Medium-sized, deep glowing red flowers suffused with vivid crimson. 18 to 24 inches tall. 2 yr., No. 2 . $80 \mathrm{c}$ each; 3 to $9,75 \mathrm{c}$ each; 10 to $29,70 \mathrm{c}$ each.

\section{ALL-AMERICA WINNER The New Floribunda MA PERKINS (Pat. 1143)}

9001 This new member of the increasingly popular Floribunda family is a strong but neatly compact grower with an abundance of $2 \frac{1}{2}$ to 3 -inch blooms. The color is deep salmon-pink changing to soft coral-pink that remains attractive until the last petal drops. Ma Perkins has a rich, sweetly pungent fragrance uncommon to this class of Roses. Bushy, heavily foliaged and hardy. $\$ 2.25$ each; 3 to $9, \$ 2.00$ each; 10 to $29, \$ 1.95$ each.

9019 Pinkie. Pat. 712. All-America winner. A baby Rose unusually perfect in form. The pink buds are Iong and slender; the open flower about 2 inches across. 24 inches tall. $\$ 1.75$ each; 3 to 9, $\$ 1.55$ each; 10 to $29, \$ 1.50$ each.

9016 Pinocchio. Pat. 484. Perfect miniature buds of soft salmon flushed gold. $\$ 1.50$ each; 3 to $9, \$ 1.30$ each; 10 to $29, \$ 1.25$ each. 9021 Red Pinocchio. Pat. 812. A new deep velvety red, considered by some to be even better than Pinocchio. $\$ 1.50$ each; 3 to 9 $\$ 1.30$ each; 10 to $29, \$ 1.25$ each.

9004 Poulsen's Bedder. The ideal Rose for mass plantings or low hedges and one of the best new pink Floribundas for the garden. The great clusters of big, lightly ruffled blooms are clear rich pink from bud to fully open blooms. A real beauty. The hardy plants, about 30 inches tall, bloom continuously all summer. $\$ 1.50$ each; 3 to $9, \$ 1.30$ each; 10 to $29, \$ 1.25$ each.

9007 Snowbank. Pat. 279. Very profuse white with blush tint. The dwarf plants with dark green, leathery foliage are admost covered with flowers. Outstanding for mass display. $\$ 1.50$ each; 3 to $9, \$ 1.30$ each; 10 to $29, \$ 1.25$ each.

9029 The Fairy. One of the finest and most useful Polyantha Roses ever introduced. Rosettes of delicate seashell-pink come in large sprays continually. The dwarf, spreading plant has small shiny foliage as pretty as boxwood. The American Rose Society gives it the highest rating in its class. $\$ 1.25$ each; 3 to $9, \$ 1.05$ each; 10 to $29, \$ 1.00$ each.

9025 Vogue. Pat. 926. An All-America winner for 1952. This hardy new Floribunda, with its beautiful flame-red buds and open blooms of deep coral-pink, is a fine addition to this group of increasingly popular Roses. The vigorous, branchy plants reach 30 to 36 inches in height and produce several crops of well-filled sprays. $\$ 2.25$ each; 3 to $9, \$ 2.00$ each; 10 to $29, \$ 1.95$ each.

9017 World's Fair. Pat. 362. Large clusters of darkest scarlet blooms are produced continuously on 30 -inch plants. $\$ 1.50$ each; 3 to $9, \$ 1.30$ each; 10 to $29, \$ 1.25$ each page 14 for amoun

to send for packing

and postage.

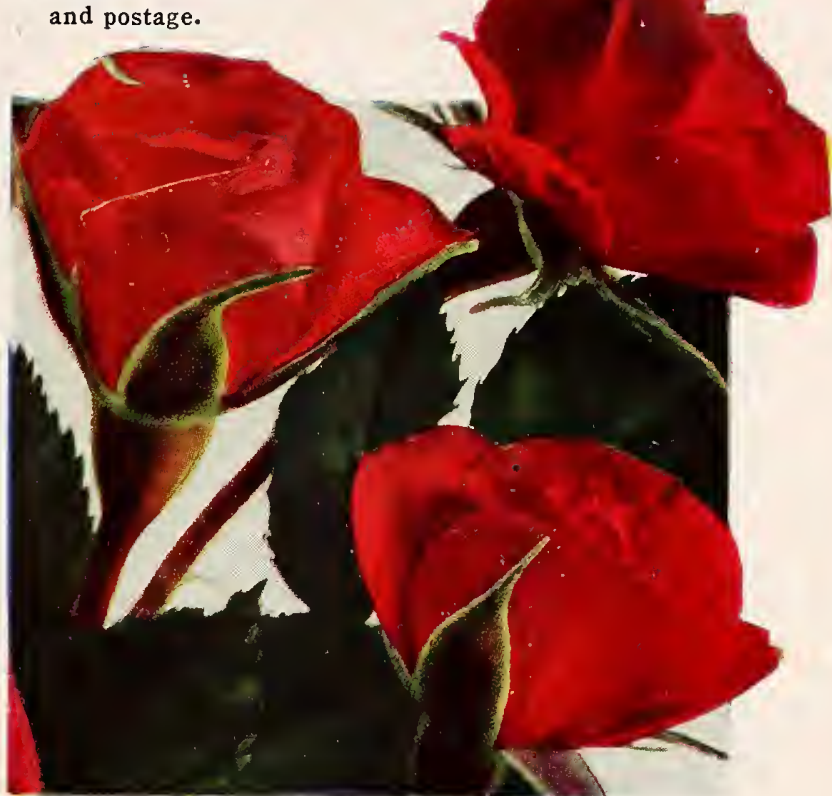

9014 FLORADORA

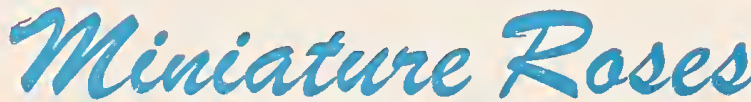

8996 Red Elf. Pat. 973. A new miniature with deep velvety Bordeaux-red flowers $3 / 4$ inch across. The tiny plant blooms profusely. $\$ 1.25$ each; 3 to $9, \$ 1.05$ each.

8997 Sweet Fairy. Pat. 748. Deep pink buds open to very double,1-inch blooms of bright apple-blossom-pink. Rich fragrance. $\$ 1.25$ each; 3 to $9, \$ 1.05$ each.

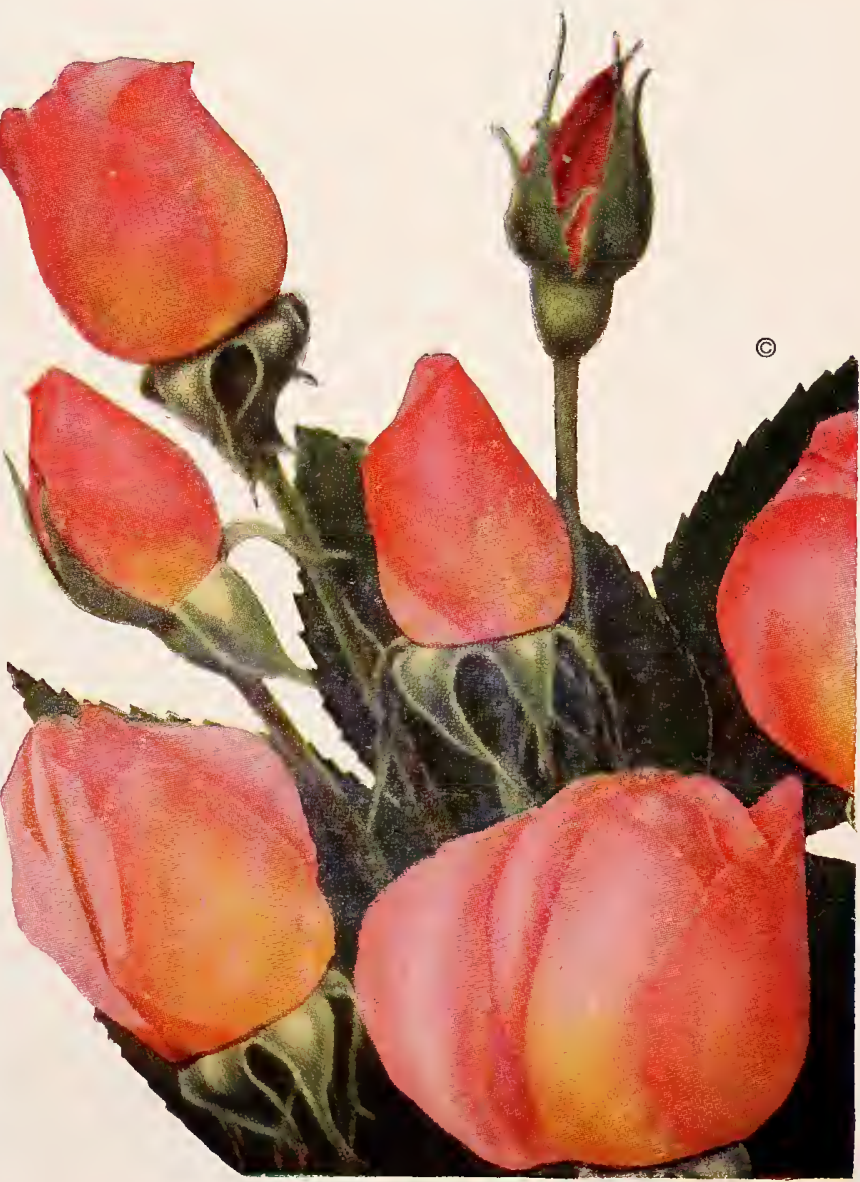

FLORIBUNDA ROSE, MA PERKINS

Pat. 1143 


\section{Everblaoming CLIMBING ROSES}

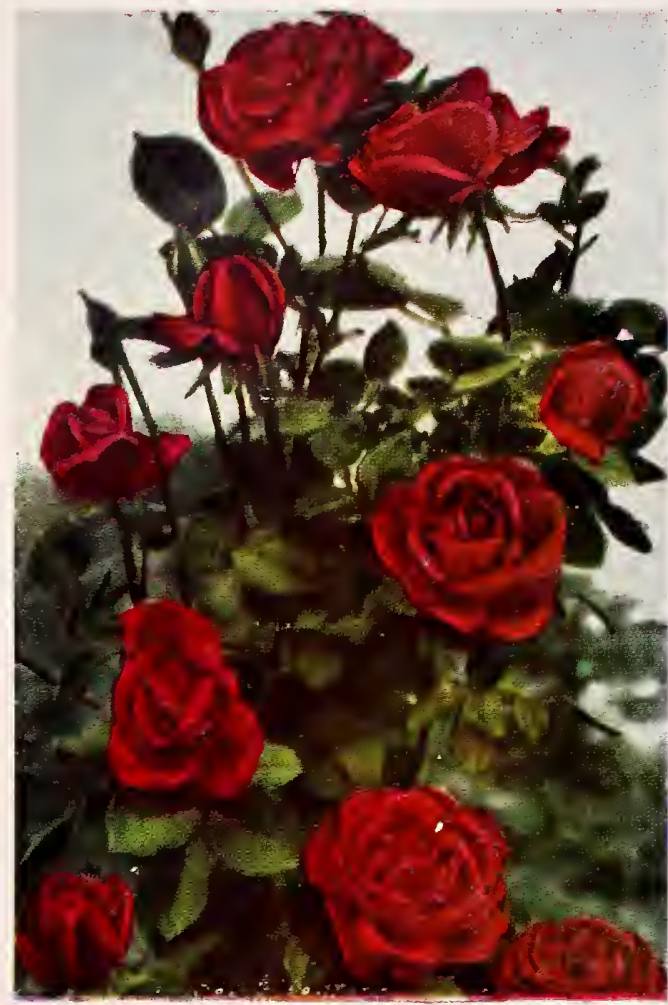

9055 CL. CRIMSON GLORY. Pat. 736

9030 Blaze. Everblooming form of Paul's Scarlet. $\$ 1.25$ each; 3 to $9, \$ 1.05$ each. 9055 Cl. Crimson Glory. Pat. 736. Deep crimson, fragrant flowers. $\$ 2.00$ each; 3 to $9, \$ 1.75$ each.

9056 Cl. Etoile de Mollande. Flowers identical to the bush form. $\$ 1.25$ each; 3 to $9, \$ 1.05$ each.

9065 High Noon. Pat. 704. A bright yellow everblooming climber. The intensity of color in the clear shining yellow buds is not equaled by any other Rose. It is not a rampant climber, but a bushy, 8 to 10 -foot pillar of shining green foliage with a wealth of well-shaped buds and brilliant unfading flowers. $\$ 2.25$ each; 3 to $9, \$ 2.00$ each.

$9070 \mathrm{Cl}$. McGredy's Ivory. Same as the bush form. \$1.25 each; 3 to 9 , $\$ 1.05$ each.

$9072 \mathrm{Cl}$. Mme. Edouard Herriot. Wonderful climber with large coral flowers. Glossy foliage. $\$ 1.25$ each; 3 to $9, \$ 1.05$ each.

9063 Golden Climber. Large, open, fragrant flowers of sunflower yellow. The shapely buds are long-pointed; the foliage glossy and abundant. $\$ 1.25$ each; 3 to $9, \$ 1.05$ each.

9083 CI. Peace. Pat. 932. The magnificent Peace Rose in climber form. Very double, cream-yellow edged pink. \$2.50 each; 3 to 9, \$2.20 each.

9074 Cl. Mme. Henri Guillot. Pat. 788. The vigorous, heavily foliaged plant is a breath-taking sight when in full bloom. Generously produced, longstemmed buds open to large blooms of brilliant flame-pink to raspberry-pink. Deliciously fragrant and one of the finest climbers. $\$ 2.00$ each; 3 to $9, \$ 1.75$ each.

9082 CI. Mrs. Sam McGredy. Pat. 394. Many beautifully formed buds and lovely flowers of richest coppery orange cover the big, vigorous plant. Foliage is luxuriant glossy green. $\$ 1.75$ each; 3 to $9, \$ 1.55$ each.

$9090 \mathrm{Cl}$. Pres. Herbert Hoover. Same flower as the bush form. $\$ 1.25 \mathrm{each}$; 3 to $9, \$ 1.05$ each.

9094 CI. Show Girl. Pat. 892. Semi-double, deep pink blooms on long stems. Vigorous plant with excellent foliage. $\$ 2.00$ each; 3 to $9, \$ 1.75$ each.

9085 Cl. Santa Anita. Pat. 834. One of the finest pink climbers. It produces recurrently Iarge double blooms of soft silvery pink. Vigorous grower. $\$ 1.75$ each; 3 to $9, \$ 1.55$ each.

9098 Cl. Talisman. Flowers same as bush form; outstanding. \$1.25 each; 3 to $9, \$ 1.05$ each.

9041 New Dawn. Long-stemmed, double, blush-pink blooms; slightly fragrant. \$1.25 each; 3 to $9, \$ 1.05$ each.

\section{Three Euerblooming Climbers}

\section{Rose Collection No. 9147}

One each of Cl. Mrs. Sam McGredy, Cl. High Noon, Cl. Crimson Glory.

(\$6.00 Value) only $\$ 5.30$

If by mail, include $35 c$ additional for packing and postage.

\section{HARDY CLIMBING ROSES}

9036 American Beauty. Deep rose-pink; fragrant.

9034 Crimson Rambler. Large clusters of scarlet flowers.

9042 Paul's Scar!et Climber. Vivid scarlet.

9048 Silver Moon. Large, pure white flowers.

Each of above Hardy Climbers, $\$ 1.25$ each; 3 to 9 of one variety, $\$ 1.05$ each

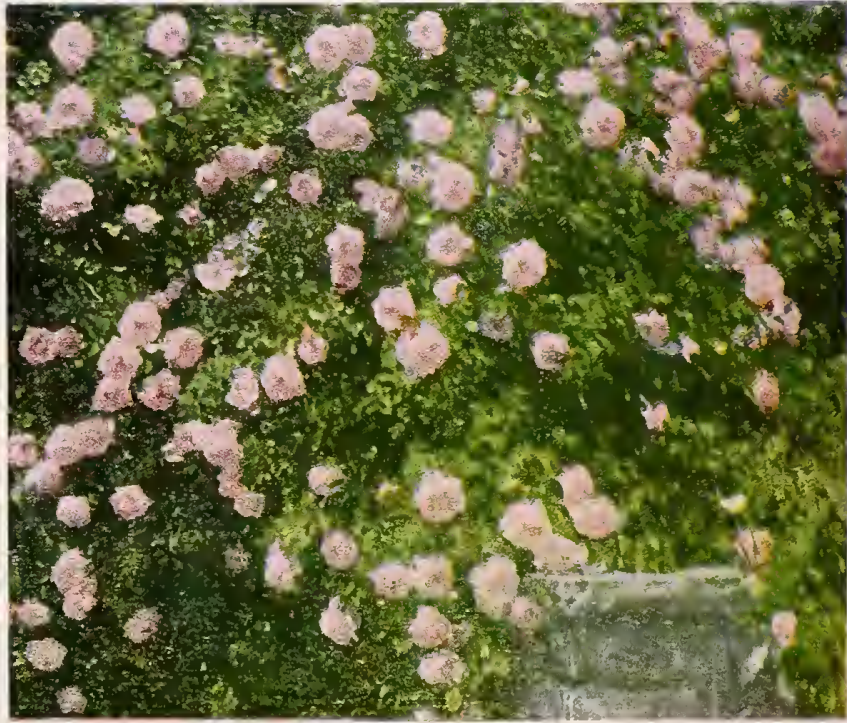

9041 NEW DAWN

\section{Shrule ROSES}

These form an appropriate background for the Hybrid Tea Rose garden and combine well with other shrubs in a border HYBRID PERPETUALS

8968 American Beauty, White (Frau Karl Druschki). Vigorous grower.

\section{SWEETBRIERS}

8984 Austrian Copper. Bright coppery red, the reverse of the petals golden yellow. 6 to 7 feet tall.

8986 Rosa Hugonis. Delicate yellow, single flowers on Iong, Price of all Shrub Roses, $\$ 1.25$ each; 3 to 9 of one variety, $\$ 1.05$ each. 


\section{Charming CLIMBERS}

\section{AMPELOPSIS}

9404 New Virginia Creeper (Engelmanni). H 35-40. Self clinging to most surfaces. 2-yr., No. 1, 90c each; 3 for $\$ 2.55$. 9406 Boston Ivy (Veitchi). Deep green foliage of leathery texture. The vine clings to wood, brick or stone wall surfaces. 3-yr. plants, $\$ 1.25$ each; 3 for $\$ 3.45$.

\section{TRUMPET-VINE - Bignonia}

9408 Mme. Galen. The most striking improvement in this family. Broader trumpets of a beautiful rich shade of orange. 2 -yr. grafted plants, $\$ 2.50$ each.

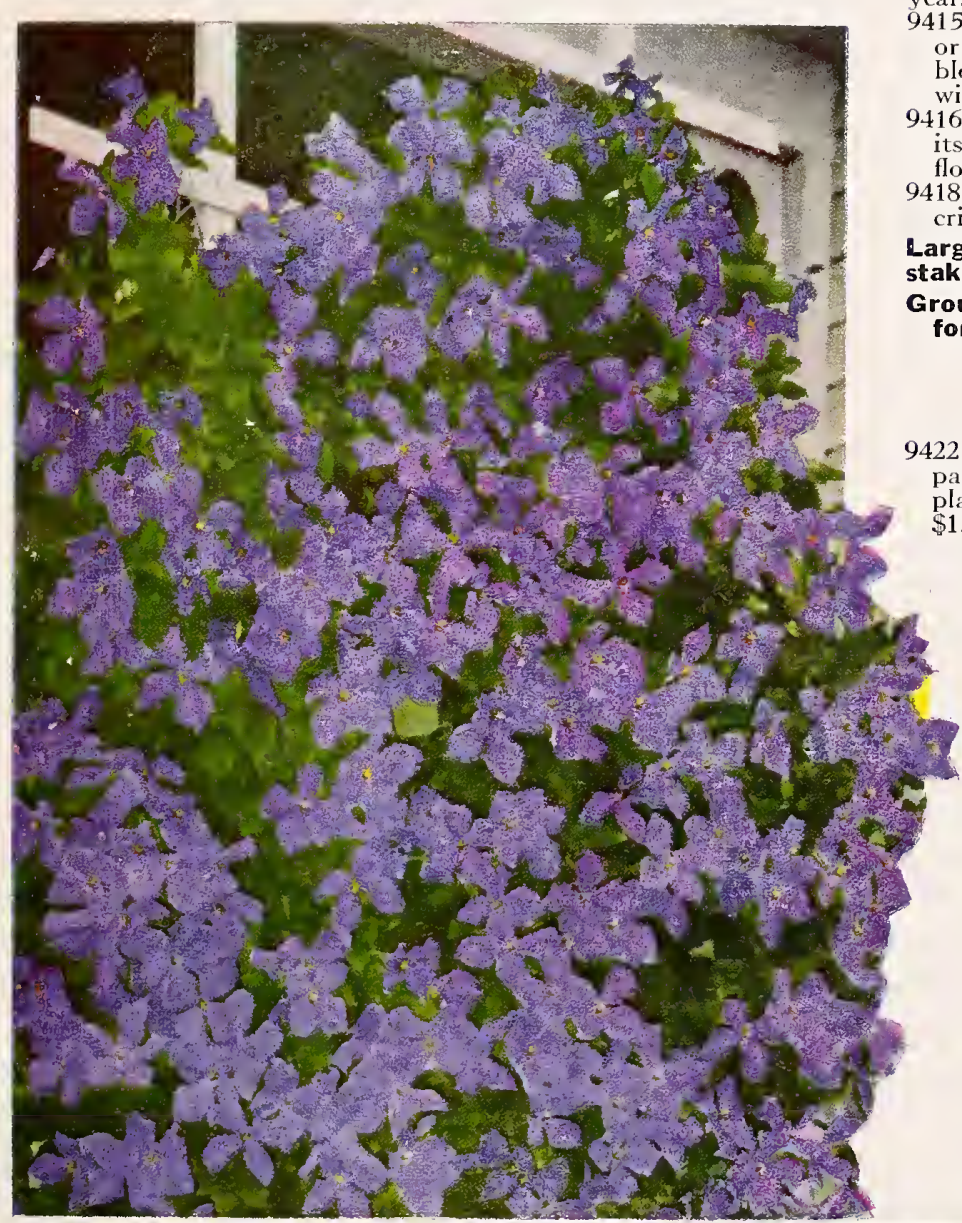

CLEMATIS Jackmani

\section{SILVER LACE VINE}

9436 Polygonum Auberti. H 40. The fastest-growing hardy vine. In late summer and fall it is covered with lacy white blooms in large clusters. 2-yr. plants, $\$ 1.25$ each; 3 for $\$ 3.45$.

\section{MAIL-ORDER INEORMATION}

All nursery stock is priced f.o.b. Salt Lake City. For all vines on your order include with your remittance an additional amount for packing and postage according to the following table.

$$
\text { Vine Sizes }
$$

2-yr, bare root............... 25 plants $\$ 0 \quad 35 \quad \$ 0 \quad 55$ 4 -in. pots.

$20 \quad 25$

1-gal. cans $60 \quad 140$

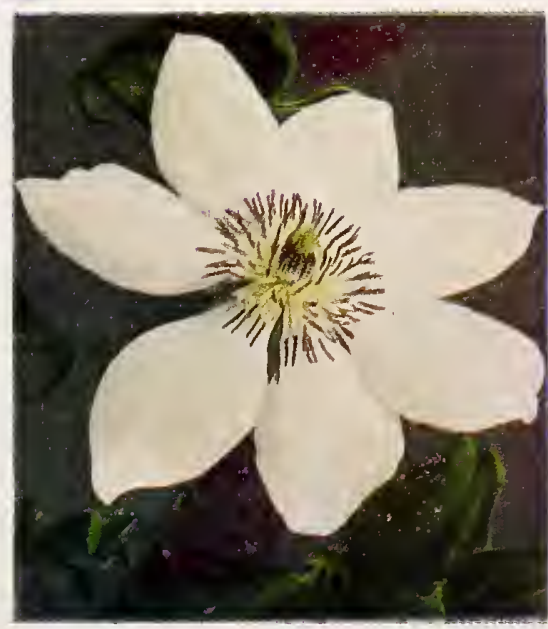

CLEMATIS Henryi

\section{CLEMATIS}

9414 Paniculata. Sweet Autumn Clematis. H 25. A stronggrowing but graceful vine. Produces an array of fragrant white flowers from August until fall. 2-yr. plants, $\$ 1.25$ each; 3 for $\$ 3.45$.

\section{Large-Flowered CLEMATIS}

A partially shaded location is ideal for the Iarge-flowered Clematis. They thrive best in a rich loam of rather light texture. The soil should be slightly alkaline and must be well drained. The plants should be set with the collar at least 2 or 3 inches below the surface. A mulch of peat moss is very helpful the first

15 Henryi. H 8. Perfectly suited to growing on small arbors or low garden walls. Outstanding for its quality and size of blooms, which often measure 8 inches across. Creamy white 6 strongly contrasting stamens.

Jackmani. H 15. Hardy and vigorous in growth covering itself in summer and early autumn with velvety violet-purple flowers.

8 Mme. Edouard Andre. H 15-20. Large flowers of velvety

Large-fiowered Clematis, established in 4-in. pots and staked, $\$ 1.50$ each.

Group Offer: 3 plants, one of each large-flowered Clematis for only $\$ 4.20$.

\section{EUONYMUS}

422 Fortunei coloratus. H 1 . An evergrcen creeper of compact form and luxuriant foliage for ground-cover work. 2-vr. plants, $\$ 1.25$ each; 3 for $\$ 3.45 ; 10$ to $29, \$ 1.10$ each; 30 to 100 ,

424 Radicans vegetus. Evergreen Wintercreeper. H 15. An excellent wall or ground-cover. 2-yr. plants, in 1-gal. containers, $\$ 1.50$ each.

\section{Lonicera - HONEYSUCKLE}

9430 Goldflame. An everblooming Honeysuckle of remarkable beauty. 2-yr. plants, $\$ 1.25$ each; 3 for $\$ 3.45$; 10 to $29, \$ 1.10$ each; 30 to $100, \$ 1.00$ each.

9432 Japonica Halliana. Hall's Japan Honeysuckle, Semi-evergreen ground-cover or climber. Fragrant white and yellow flowers. 2-yr. plants, $75 \mathrm{c}$ each; 3 for $\$ 1.95$; 10 to $29,55 \mathrm{c}$ each; 30 to $100,50 \mathrm{c}$. each.

\section{Hedera. IVY}

9425 English Ivy (Helix). H 20. Handsome climber or ground-cover; excellent on north walls and under shrubs. Needs protection from the winter sun.

In $21 / 2$-in. pots, $50 \mathrm{c}$ each; 3 for $\$ 1.44 ; 10$ to 29,45 c each; 30 to $100,40 \mathrm{c}$ each.

In 4 -in. pots, $90 \mathrm{c}$ each; 3 for $\$ 2.55$; 10 to $29,80 \mathrm{c}$ each. 9426 Helix baltica. Baltica lvy. The hardicst of the Ivies. A small-leaved variety that is excellent for north and west exposures.

In $21 / 2$-in. pots, $50 \mathrm{c}$ each; 3 for $\$ 1.44 ; 10$ to 29 ,
45 c each; 30 to 100 , $40 \mathrm{c}$ each.

In 4 -in. pots, 90c each; 3 for $\$ 2.55$; 10 to 29,80 c each.

\section{WISTERIA}

9438 Sinensis. H 30. The oId favorite lavender-blue variety. Long clusters of fragrant blooms appear in late spring. 2-yr. plants, $\$ 1.25$ each; 3 for $\$ 3.45$.

9447 Royal Purple (Floribunda). H 30 to 40 Most outstanding of the modern Wisterias. Large, deep violet-purple clusters. 2-yr.-old grafted plants, $\$ 3.00$ each; 3 for $\$ 8.25$.

*Large and heavy shipments must be sent by express or motor freight. 


\section{Evergreens -}

\section{ARBORVITAE (Thuja)}

9476 Orientalis pyramidalis. Western Arborvitae. Thishardy variety, which is native in Western America, has the richest, most Iuxuriant green color of all the Arborvitae. 3 to $4 \mathrm{ft}$., $\$ 10.00$ each; 4 to $5 \mathrm{ft}$., $\$ 12.00$ each.

9474 Orientalis elegantissima. Gold-Tinged Column Arborvitae. A narrow pyramidal evergreen of tall and stately form. Highly prized as an accent subject because of its distinct and contrasting color. In gal. cans, $\$ 1.50$ each; 10 to $29, \$ 1.30$ each. 30 to 36 in., B\&B, $\$ 7.50$ each; 3 to $4 \mathrm{ft}$., $\mathrm{B} \& \mathrm{~B}, \$ 10.00$ each.

\section{Dwarf Varieties}

9488 Berckınan's Dwarf Evergolden Arborvitae. (Orientalis aurea nana.) The most wanted Arborvitae. Dwarf, golden tipped pyramidal. In gal. cans, $\$ 1.50$ each; 10 to 29 , $\$ 1.35$ each. 18 to 24 in., $\$ 4.75$ each; 24 to 30 in., $\$ 6.50$ each.

9484 Orientalis meldensis (Biota Bonita). Dwarf habit, neat pyramidal form and rich deep green foliage that grows vertically with a pressed appearance. In gal. cans, $\$ 1.50$ each; 10 to $29, \$ 1.30$ each. 24 to 30 in., \$6.50 each; 30 to 36 in., $\$ 8.00$ each.

\section{PYRAMIDAL AND NOVELTY JUNIPERS}

9469 Chinensis Keteleeri. A beautiful evergreen with a very pleasing, pyramidal shape and dark green foliage. The most adaptable upright Juniper for partially shaded spots. 3 to $4 \mathrm{ft}$., $\$ 10.50$ each.

9462 Chinensis pyramidalis, Blue. Column Juniper. One of the most adaptable to use in landscape plantings. Its rich blue-green color is a pleasing complement to all colors of brick and stucco. In gal. cans, $\$ 1.50$ each; 10 to 29 , $\$ 1.35$ each. 30 to $36 \mathrm{in.}, \$ 7.50$ each; 3 to $4 \mathrm{ft}$., $\$ 10.50$ each.

9464 Scopulorum. Colorado Juniper. Compact, columnar growth from a single central stem. Unusual silver-blue color. 18 to 24 in., $\$ 4.50$ each; 24 to 30 in., $\$ 6.50$ each; 30 to 36 in., $\$ 7.50$ each; $31 / 2$ to $4 \mathrm{ft}$., $\$ 10.50$ each; 4 to $5 \mathrm{ft}$., $\$ 12.75$ each.

9466 Virginiana Cannarti. Cannart Red Cedar. The deepest, richest green color of all Junipers. Cannart Juniper may be trimmed and maintained at any size desired. 30 to $36 \mathrm{in}$., $\$ 7.50$ each; 3 to $4 \mathrm{ft}$., $\$ 10.50$ each; 4 to $5 \mathrm{ft}$., $\$ 12.75$ each.

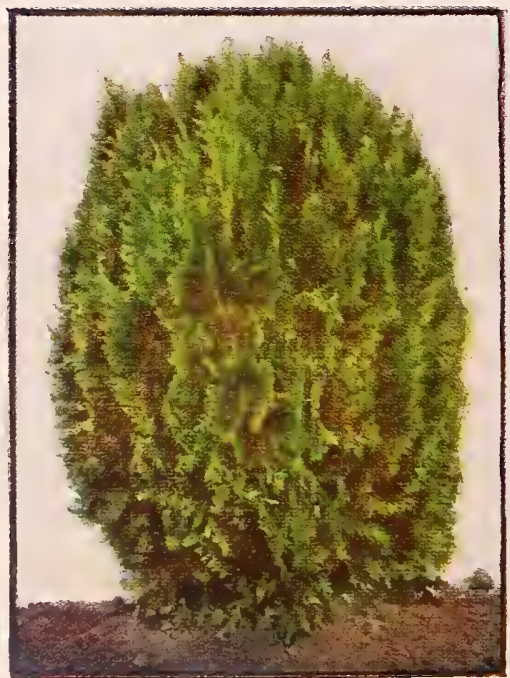

BERCKMAN'S ARBORVITAE
All Evergreens are priced f.o.b. Salt Lake City. Express or motor freight shipment is recommended.

PYR AMIDAL AND NOVELTY JUNIPERS, continued

9468 Dundee (Virginiana pyramidiformis). One of the most valuable of m o tern Junipers. It is a moderate grower with beautiful blu sh green foliage in spring and summer, turning to an unusual purplish plum color in the fall and winter. 3 to $4 \mathrm{ft}$., $\$ 10.50$ each; 4 to $5 \mathrm{ft}$., $\$ 12.75$ each.

9461 Silver-Blue Globe. A low-growing blue Juniper trimmed to formal shape. Easily maintained as globe specimens at either side of an entrance or porch. 18 to 24 in., $\$ 7.50$ each.

9455 Virginiana globosa. Globe Red Cedar. $4 \mathrm{ft}$. Best of all the globe forms of Juniper. It is slow growing, dense in habit, with dark green foliage. 15 to 18 in., $\$ 6.50$ each.

\section{SPREADING JUNIPERS}

9450 Chinensis Pfitzeriana. Pfitzer Juniper. Quick growing. The most widely planted spreading Juniper. In gal. cans, 1 to $9, \$ 1.50$ each; 10 to $29, \$ 1.35$ each. 15 to $18 \mathrm{in}$., $\mathrm{B} \& \mathrm{~B}, \$ 5.00$ each; 18 to 24 in. B\&B, $\$ 6.00$ each; 24 to 30 in., $\$ 7.00$ each.

9459 Chinensis Pfitzeriana, Compact. A comparatively rapid grower developing into a beautiful plant in a short time, but never attaining the extreme proportions of Pfitzer Juniper. 18 to 24 in., $\$ 6.50$ each; 24 to 30 in., $\$ 7.50$ each.

9451 Chinensis Pfitzeriana, Silver-Blue. Closely resembles Pfitzeriana in habit of growth but has silvery blue foliage. Silver-Blue Pfitzer is very effective as a colorcontrast plant among the darker-colored varieties. In gal. cans, $\$ 1.50$ each; 10 to $29, \$ 1.35$ each. 18 to 24 in., $\$ 6.00$ each; 24 to 30 in., $\$ 7.00$ each; 30 to 36 in., $\$ 8.50$ each.

9452 Sabina tamariscifolia. Especially desirable in plantings where space is limited or when used against a house with a low foundation. It is a small, compact grower attaining a spread of only 6 to 7 feet. In gal. cans, $\$ 1.50$ each; 10 to $29, \$ 1.35$ each. 15 to 18 in., $\mathrm{B} \& \mathrm{~B}, \$ 5.50$ each; 18 to 24 in., B\&B, \$6.50 each.

9460 Andorra (Horizontalis plumosa). A true creeping Juniper, and perhaps the most charming of the low-growing varieties. Grows 6 to 8 feet across and is the best for planting in partial shade. 18 to 24 in., $\$ 6.00$ each.

9456 Sargenti Blue. A very low, creeping form growing only 8 to 12 inches above the ground and spreading 6 to 8 feet. The bright bluish green foliage creates a pleasing contrast with the ordinary green of other plants. 18 to 24 in., $\$ 6.00$ each; 24 to 30 in., $\$ 7.00$ each; 30 to 36 in., $\$ 8.50$ each.

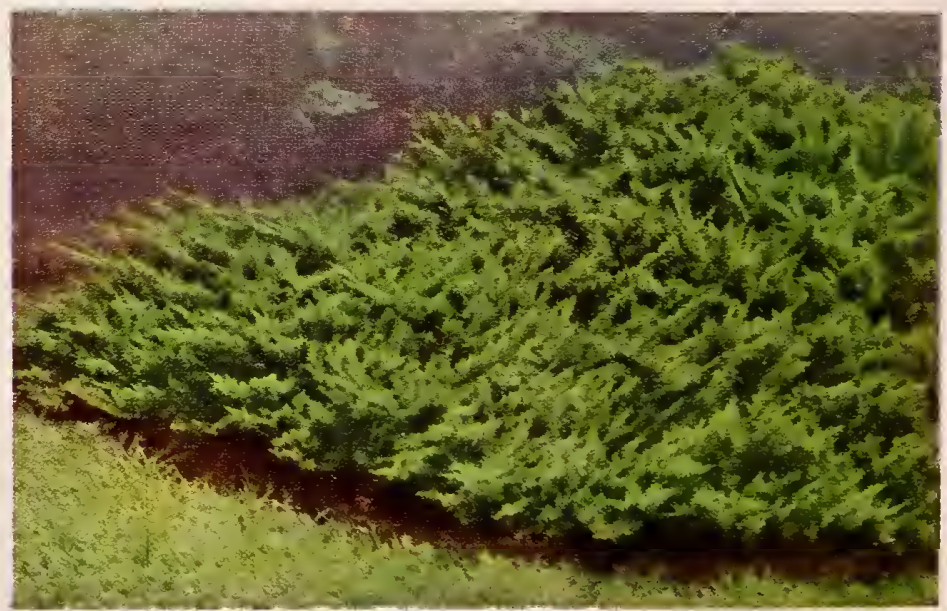

SARGENTI JUNIPER 


\section{CONIFERS}

\section{Picea - SPRUCE}

9510 Colorado Green (Pungens). Tall, stately tree growing 40 fcet tall or more. 30 to 36 in., $\$ 7.00$ each; 3 to $4 \mathrm{ft}$., $\$ 10.00$ each.

9508 Colorado Blue (Pungens glauca). A magnificent tree growing to 40 fect, with a spread of 18 to 20 feet. 24 to 30 in., $\$ 8.00$ each; 3 to $4 \mathrm{ft}$., $\$ 15.00$ each.

\section{PINUS . Pine}

9494 Austrian (Nigra). A beautiful evergreen shade tree reaching a height of 40 feet. The leaves are from 4 to 5 inches long, and deep rich green. Gas and smoke have no effect on its growth. 30 to 36 in., $\$ 7.50$ each.

\section{JAPANESE YEW}

9514 Taxus cuspidata. Spreading from. This low-growing, dark green plant helps fill the need for small shade-loving evergreens for landscaping the modern home. Japanese Yew will endure the low temperatures of Rocky Mountain winters but should be planted in a partially shaded location, protected from dry winds. It thrives near pools or streams where the humidity is relatively high and succeeds where shade is quite heavy, as on the north side of a building. 18 to 24 in., $\$ 6.50$ each.

9511 Hicks (Media Hicksi). 5 to $6 \mathrm{ft}$. A narrow, columnar Yew with vertical branches and rich, dark, glossy green foliage. One of the most resistant to heat and drought. 24 to 30 in., $\$ 7.50$ each.

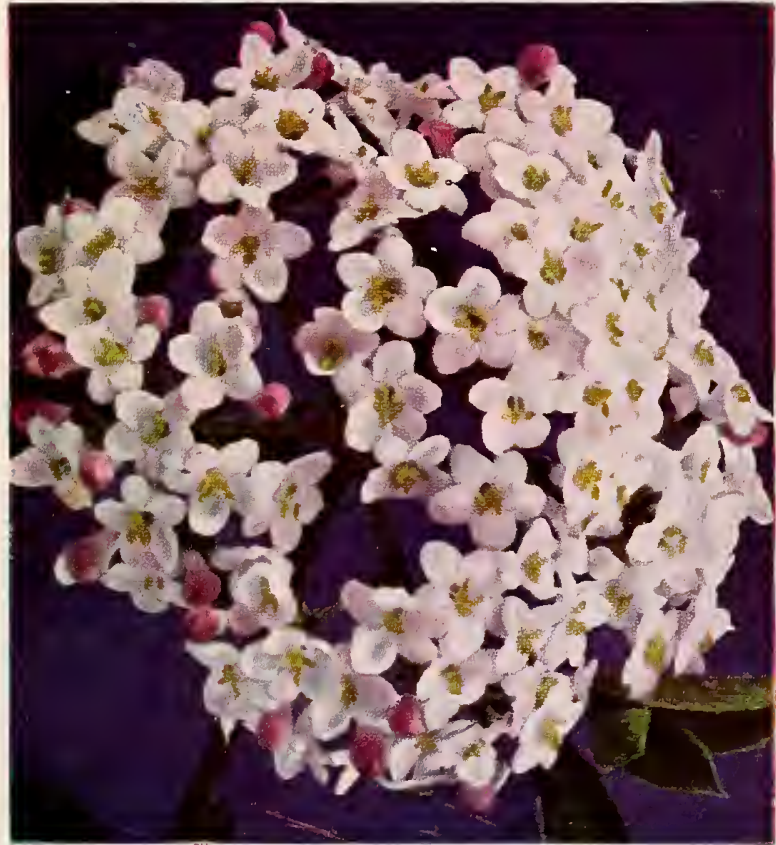

VIBURNUM BURKWOODI

\section{VIBURNUM}

9538 Burkwoodi. Gardenia-Scented Snowball. Most outstanding shrub introduction in recent years. Waxy, pinkish white flowers. The rich, glossy, semi-evergrcen foliage turns purplish bronze with winter weather. 4 feet tall. In gal. cans, $\$ 1.50$ each; 10 to $29, \$ 1.35$ each. 30 to $36 \mathrm{in}$., $\mathrm{B} \& \mathrm{~B}, \$ 5.00$ each.

Also available are many varieties of Evergreens not listed here. Please write for information on other kinds in which you might be interested.

\section{BOXWOOD - Buxus}

9519 Truedwarf Boxwood (Sempervirens suffruticosa). Dense, ncarly globe-shaped plants with smali, glossy green leaves. It is especially desirable for the front of foundation plantings because of its neat rounded form. Grows best in partial shade. 24 in., $\$ 6.90$ each.

9520 Sempervirens. A formal plant for gardens where pyramids and globes are desired. Foliage glossy and dense. In gal. cans, $\$ 1.50$ each; 10 to $29, \$ 1.35$ each. 15 to 18 in; $\$ 4.50$ each; 24 in., $\$ 6.00$ each.

\section{COTONEASTER}

9523 Apiculata. $3 \mathrm{ft}$. A relatively new plant that is proving to be one of the most important in the small shrub group. Dark glossy green leaves and pinkish white flowers which are followed by exceptionally large red fruits. In gal. cans, $\$ 1.50$ each; 10 to $29, \$ 1.35$ each. In 3-gal. cans, $\$ 5.00$ each.

\section{EUONYMUS}

9528 Japonicus. A shade-loving evergrcen shrub, which thrives on the north or east side of the house. The large, thick, glossy leaves hang on all winter. 8 feet tall. In gal. cans, $\$ 1.50$ each; 10 to $29, \$ 1.35$ each. 24 to 30 in., in 3-gal. cans, $\$ 5.00$ each.

\section{MAHONIA}

9530 Aquifolium. Oregon Hollygrapc. Shiny leaves in attractively changing shades of green. 5 feet tall. In gal. cans, $\$ 1.50$ each; 10 to $19, \$ 1.30$ each. 18 to 24 in., heavy field grown, $\$ 4.75$ each.

\section{PYRACANTHA}

9534 Coccinea Lalandi. Leaves dark, glossy and evergreen. Flowers white, in clusters, followed by orange-scarlet berries. 10 feet tall. In gal. cans, $\$ 1.50$ each; 10 to 29 , $\$ 1.35$ each. 18 to 24 in., in 3-gal. cans, $\$ 3.50$ each. 30 to 36 in., in 3-gal. cans, $\$ 4.75$ each.

9536 Coccinea pauciflora. Dwarf Pyracantha. The hardiest Pyracantha, also outstanding for its compact, rounded, formal habit. 6 feet tall. In gal. cans, $\$ 1.50$ cach; 10 to 29 , $\$ 1.35$ each. 18 to 24 in., in 3-gal. cans, $\$ 3.50$ each; 10 to $29, \$ 3.20$ each.

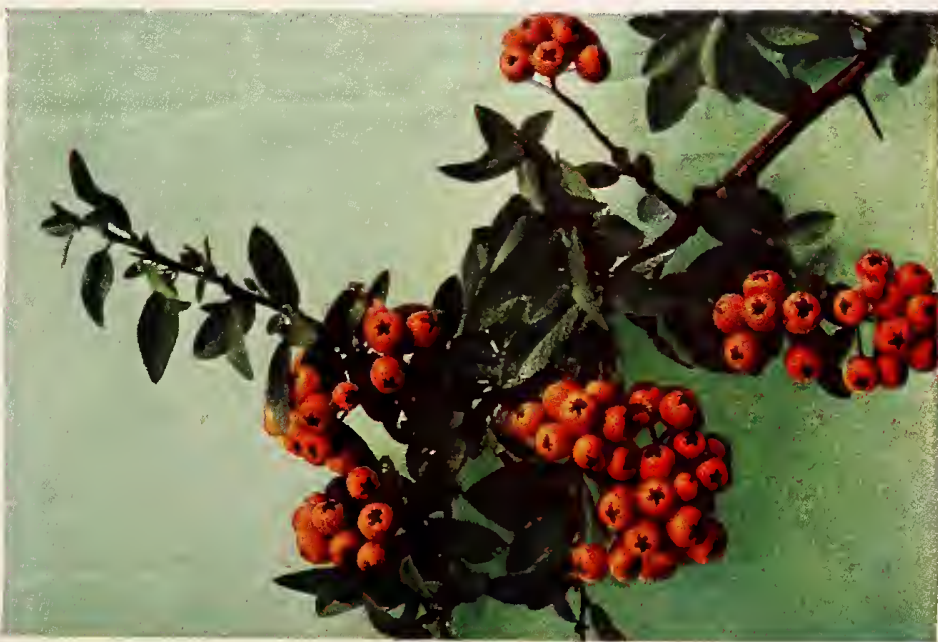

PYRACANTHA COCCINEA LALANDI 


\section{P.-W.'s Ornamental and}

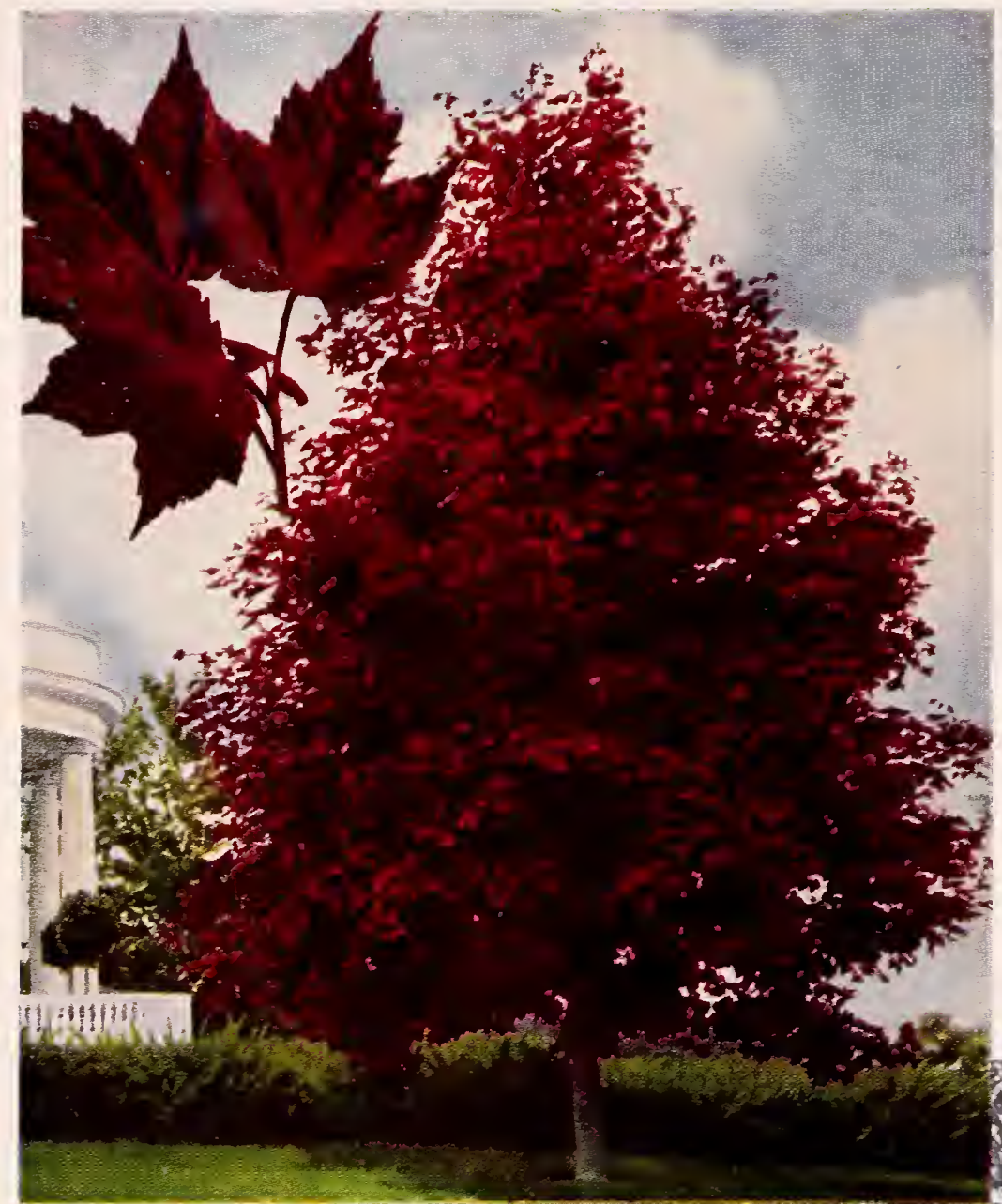

\section{MALE ASH TREES}

The absence of the seasonal litter of seeds and the resulting crop of troublesome seedlings accounts for the widespread use of these specially propagated trees. In addition, the foliage of male trees is more abundant, more glossy and luxuriant.

9554 Male Excelsior. H 75. Broad head and abundant glossy foliage. A permanent hardwood tree that is clean, tough and thrives in all climates.

5 to $6 \mathrm{ft}$., $\$ 3.50$ each; 3 for $\$ 9.75$.

6 to $8 \mathrm{ft}$., $\$ 4.50$ each; 3 for $\$ 12.75$.

8 to $10 \mathrm{ft}, \$ 5.00$ each. 3 for $\$ 14.25$.

10 to $12 \mathrm{ft}$., $\$ 6.00$ each; 3 for $\$ 16.80$.

9550 Male Green. H 50-60. A tall, pyramidal tree with a rounded head. The vigorous habit and dense foliage make these male trees noticeably superior.

5 to $6 \mathrm{ft}$., $\$ 3.50$ each; 3 for $\$ 9.90$.

6 to $8 \mathrm{ft}, \$ 4.50$ each: 3 for $\$ 12.75$.

8 to $10 \mathrm{ft}$., $\$ 5.00$ each; 3 for $\$ 14.25$.

10 to $12 \mathrm{ft}$., $\$ 6.00$ each; 3 for $\$ 16.80$.

9555 Modesto Male (Fraxinus velutina glabra). H 25-35. Moderate in size, clean, disease free and reasonably fast growing. Dense glossy green foliage. There are no seeds, and the leaves drop over a short period in the fall. We highly recommend this as the most outstanding fast-growing shade tree 6 to $8 \mathrm{ft}$., $\$ 3.50$ each; 3 for $\$ 9.75$.

\section{BIRCH - Betula}

9542 European White (Pendula). A tall, distinctive, white-barked tree. The leaves are nearly round but abruptly pointed. 6 to $8 \mathrm{ft}$., $\$ 3.00$ each; 3 for $\$ 8.40$. 8 to $10 \mathrm{ft}$., $\$ 4.00$ each; 3 for $\$ 11.25$.

\section{MAIL ORDER INFORMATION}

All trees are priced f.o.b. Salt Lake City. Orders for deciduous nursery stock can be shipped at any time during the spring so long as the plants are dormant. Early plantings give best results.

\section{SHIPPING WEIGHT-ORNAMENTAL TREES}

\section{Size.} $4-5 \mathrm{ft} .5-6 \mathrm{ft} .6-8 \mathrm{ft} .8-10 \mathrm{ft} .10-12 \mathrm{ft}$. One tree. Each additional tree ...... 3 lbs. 5 lbs. 8 lbs. 10 lbs. 12 lbs. Express or Motor Freight recommended for all trees 4 to 5 feet or larger.

\section{ACACIA}

9614 Orchid-flowering. H 35 . A beautiful tree with long compound leaves and clusters of deep orchid-pink flowers in June. A medium fast grower. 6 to $8 \mathrm{ft}$., $\$ 4.50$ each; 3 for $\$ 12.75$.

\section{MOUNTAIN-ASH · Sorbus}

9552 Aucuparia. European Mountain-Ash. H 45. White flowerclusters 5 inches across, followed by orange-red berries. 6 to $8 \mathrm{ft}$., $\$ 3.75$ each; 3 for $\$ 10.50$.

\section{ASH . Fraxinus}

9548 Pennsylvanica lanceolata. Green Ash. H 50. Shapely, round top with dark green foliage. 6 to $8 \mathrm{ft}$., $\$ 3.50$ each; 3 for $\$ 9.75$.

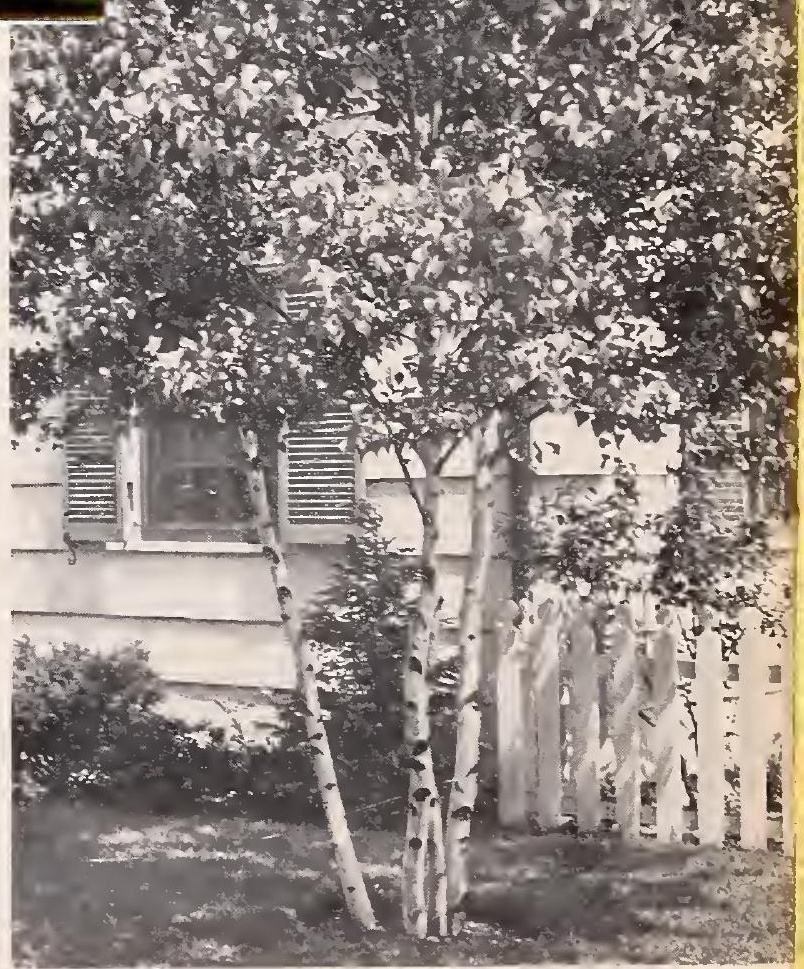

WHITE BIRCH (Betula pendula) 


\section{ALFALFA (Lucerne) Wonder cropo of the West}

2578 Ranger. This new variety is highly resistant to bacterial wilt Being very similar to Common or Hardy Desert in habit of growth and soil requirements, it is weII adapted to northern areas. In localities where bacterial wilt is a problem, a stand of Ranger will remain indefinitely.

2580 Grimm. Especially recommended for shallow soils, those underlaid with hardpan, or where the watertable is near the surface. The stems and leaves are of somewhat finer and leafrer quality than Hardy Desert Alfalfa. It is susceptible to bacterial wilt and is not recommended for areas of severe infestation.
2590 Ladak. Tests at nearly every northern and western Experiment Station show Ladak Ieading on tonnage, long life, drought-resistance, and winter hardiness. It has also shown marked resistance to bacterial wilt. Because Ladak makes heavy first and second crops but little third, it is especially recommended for high elevations.

2560 Hardy Desert. (Utah Common.) Very winter hardy and extremely drought resistant because of its long tap root. An exceptionally heavy producer. Sow 10 to 15 pounds per acre.

\section{HYBRID FIELD CORN}

Sow in drills 3 feet apart, using approximately 15 pounds of seed per acre.

\section{PORT-WALCO HYBRID No. 100}

Top Silage Producer

Maturity 100 to 110 days. Since its introduction growers in most areas have reported heaviest tonnage per acre in both green fodder and dry weight with Port-Walco Hybrid 100. It is a prodigious yielder of good solid ears that are long and thick, with very little taper. A strong and vigorous grower, producing tall, succulent stalks. Then too, the ears are set at a good height so there is little or no stalk breakage.

\section{PORT-WALCO HYBRID No. 90}

Best of the 90 to 100-day maturity Corns. The dark green plants of this high-yielding early hybrid retain their rich color even after the ears are well matured. This condition makes possible a feed of greater nutritive value. The ears are medium size and thick with deep kernels. In U.S.A.C. tests at various Utah stations Port-Walco No. 90 was one of the highest-yielding varieties.

\section{PORT-WALCO HYBRID No. 120}

The outstanding silage variety, maturing in 110 to 120 days. Not only is it the heaviest fodder producer in our hybrid list, but it yields an equally good grain crop. Its short shanks permit easy harvesting and handling for silage purposes. The plants of No. 120 are rich dark green, retaining their color until after the ears are well matured. As silage, it possesses both higher food value and higher palatability.

\section{OPEN-POLLINATED CORN}

\section{MINNESOTA No. 13}

The leading all-round, open-pollinated variety. A 90-day dent Corn, acclimated to this area. It is the heaviest producer of the medium-early varieties. Plants grow 7 to 8 feet tall, bearing ears 9 to 10 inches long. Makes splendid ensilage.

\section{CLOVER FOR MEADOWS AND PASTURES}

2600 Alsike. Recommended for hay crops sown by itself or with timothy or Red Clovers. The use of Alsike Clover is increasing rapidly; cattle prefer it to other varieties. Sow at the rate of 6 or 8 pounds per acre; sown in mixtures, 3 to 4 pounds per acre is sufficient. Very winter hardy. Does best on damp soils. Used in pasture mixture with grasses.

2620 Ladino. A giant form of the common White Dutch Clover and like the latter is a long-lived perennial. After being grazed, new leaves develop quickly, complete recovery occurring in 17 to 28 days. It is strictly a crop for irrigation. Sow in early fall or spring at the rate of 3 to 5 pounds per acre, 1 to 2 pounds in mixtures.

2630 Medium Red (Trifolium pratense). A dependable, all-round variety for farmers and stockmen. It makes two hay crops each year. Sow in either spring or early fall at the rate of 15 pounds to the acre. It is good in pastures with grasses as a companion crop.

2640 Strawberry (Tall Variety). Resembles the Common White Dutch in appearance but is much hardier and adapted to a wider range of soil and moisture conditions. Will thrive in soils having a high alkaline content and will survive flooding for a period of 30 to 60 days. Highly recommended as a pasture crop because of palatability and hardiness.

\section{About Prices}

From tIme to time we wIII be sending our customers special FIELD SEED LISTS to correct changes in market prices. If you are not receiving them, please inform us.

\section{SWEET CLOVER}

2610 Hubam. The richest honey-producing Clover. An annual sweet Clover which grows rapidly, attaining a height of 6 to 7 feet. It is very valuable for pasturage and hay when cut before it gets too old. Also used to great advantage as a cover crop or for green manure. Sow 12 to 15 pounds per acre in fall or spring.

2660 White Blossom (Melilotus alba). Its value in the redemption of alkali lands cannot be overestimated. It grows in a variety of soils - heavy, light, wet or dry, almost anywhere except in acid soil. Sow 15 to 20 pounds per acre.

2666 Yellow Blossom (Melilotus officinalis). Finer in the stalk and more palatable when mature than White Blossom, and has the same soil adaptation. Its refinement of stalk and palatability make it a good pasture or hay crop.

\section{FIELD SEED PRICES}

Prices on all field seeds are quoted on page $5-8$. Since the market changes rapidly on Field Seeds, the prices quoted herein are subject to change without notice. All quotatlons are $\mathbf{f , o . b . ~ S a l t ~ L a k e ~ C i t y , ~ U t a h . ~}$ 


\section{P.-W.'S PASTURE MIXTURES}

Formulated for HIGHER PALATABILITY

MAINTAINED PRODUCTIVITY • WIDE SOIL ADAPTABILITY

2670 Mixture A. For well-drained irrigated land, or damp fertile soil.

Ladino................................. $1 \mathrm{lb}$.

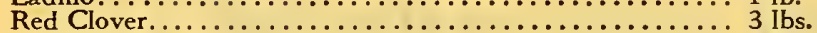

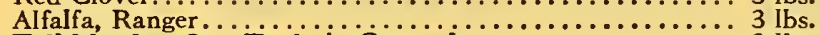

Tall Meadow Oat, Tualatin Groated................. 3 Ibs.

Orchard Grass.................................. 5 Ibs.

Smooth Brome............................... 4 lbs.

Total per acre.......................19 lbs.

2676 Mixture B. For alkaline and wet soils.

Alsike ................................... 2 lbs.

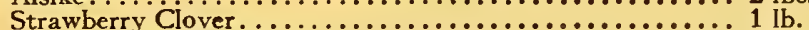

Sweet Yellow Clover.............................. 3 Ibs.

Reed Canary Grass . . . . . . . . . .

Alta Fescue..................................... 5 lbs.

Smooth Brome.

Total per acre......................... Ibs.

\section{AFRAID OF BLOAT?}

Bloat, the long-feared killer of thousands of cattle, can usually be prevented by observing these pasture rules:

(1) Plant a properly balanced pasture mix formula. Legumes are necessary for highest production, and they are relatively safe provided they do not exceed 60 per cent of the forage.

(2) Wait until legumes have reached the bud stage before pasturing.

(3) Practice restricted grazing. Animals allowed to range over too wide an area will select the most succulent legume plants which cause the bloat.

(4) Make certain that animals are not hungry when turned into a new pasture.

\section{GRASS for Range, Meadow, Pasture}

\section{MOUNTAIN BROME GRASS (Bromus marginatus)}

This stout perennial bunch grass is very common in altitudes of 5000 to 10,000 feet. It has a very wide range of soil adaptation, varying from fairly moist loamy soils where the best growth is made, to fairly dry, gravelly soils. Mountain Brome Grass, when young, is grazed closely by all kinds of livestock. Where it can be cut for hay, it makes a very frne feed for horses and cattle.

It is an exceptional grass for the reclamation of land inaccessible to farm machinery, for good stands may be obtained by broadcasting on areas where seedbed preparation is not possible. Sow 10 to 20 pounds per acre.

\section{MEADOW FESCUE}

Very productive of bright green leaves, supplying forage from early spring until late fall. Well suited to alkaline soils. Sow 20 to 30 pounds per acre.

\section{SMOOTH BROME GRASS (Bromus inermis)}

Smooth Brome is one of the outstanding grasses for the Intermountain area, being well adapted to arid regions where rainfall is relatively low. It is the most palatable of all the important grasses, surpassing even the well-known Kentucky Blue Grass in this respect. Smooth Brome is a long-lived perennial with numerous creeping rootstalks that form a dense heavy sod, making it capable of standing much abuse as a pasture grass. Brome thrives especially well on a rich loamy soil; but in the wild state it grows in dry, gravelly soils, or even in pure sand. Recent experiments have shown it to succeed in alkaline soils.

The stems attain a height of 2 to 3 feet. Two cuttings of hay are generally obtained in a season, yields ranging from 1 to 4 tons per acre. Sow 15 to 20 pounds per acre on irrigated land or 8 to 10 pounds per acre on dry land. Drilling is preferable to broadcasting wherever possible.

\section{ORCHARD GRASS}

\section{(Dactylis glomerata)}

This very early pasture grass furnishes feed at least three weeks before most other grasses. Even after close grazing, a ten-day interval is sufficient for another growth. It makes a lieavy sod and gives splendid pasture until late in the fall. Withstands drought and is very hardy. An excellent variety for use in pasture mixtures. Sow 15 to 20 pounds per acre when seeded alone.

\section{PERENNIAL RYE GRASS}

Adapted for plantings on alkaline soils. Used as an ingredient in hardy lawn mixtures. Sow 15 to 25 pounds per acre.

\section{INTERMEDIATE WHEAT GRASS}

This hardy perennial sod-forming grass begins growth early in the spring and will reach a height of 3 or 4 feet before growth ceases in midsummer due to lack of moisture. Good growth recovery is made in late summer or early fall with the return of moisture and cool temperatures. The abundant forage is relished by all classes of livestock in all stages of growth, comparing favorably in this respect with Smooth Brome. Intermediate Wheat in the Intermountain area is well adapted to range Iands under 9000 feet that receive in excess of 12 inches of annual rainfall. It is slightly more drought resistant than Smooth Brome, but less hardy and drought resistant than Crested Wheat. It is a high producer and weIl adapted on range land supporting oakbrush, serviceberry, and in open aspen areas.

Excellent seedling vigor permits relatively low seeding rates of from 6 to 10 pounds per acre, which can be made in early spring or late fall.

\section{TALL WHEAT GRASS (Agropyron elongatum)}

Tall Wheat Grass was found by plant explorers in the early 1930's growing in salt marshes in northern Turkey. It is a somewhat coarse, erect perennial with a bunch-type growth. An abundance of long basal and stem leaves makes it a high forage producer comparing favorably with other Wheat grass varieties. The mature plant is tall, often reaching a height of 5 feet and even more under irrigation.

The outstanding advantage of Tall Wheat Grass is its tolerance of wet alkaline conditions. This grass has produced high yields on land that has been considered worthless for cash crops. It stands up well under both cold and drought conditions.

Unlike Intermediate Wheat and Crested Wheat grasses which become dormant at the beginning of summer. Tall Wheat grass continues growth as long as any moisture is a vailable. Although Crested Wheat is hardier than Tall Wheat the Iatter variety excels as forage producer during hot weather and on alkaline soils.

Fall plantings on a well-packed seed bed drilled at from $1 / 2$ to $3 / 4$ inch in depth have generally given the best results. Seeding rate is 6 to 10 pounds per acre. 


\section{GRASS FOR RANGE, MEADOW, PASTURE, continued}

\section{CRESTED WHEAT GRASS \\ (Agropyron cristatum)}

This wonderful ranch and range grass grows earlier in the spring and later in the fall because of its ability to grow at low temperatures. As a hay crop it is very nutritious and palatable and stands wel under grazing. It has made a most remarkable showing under aric conditions, succeeding where other varieties fail. Crested Wheat is a long-lived grass. It is relished by livestock and adapts itsclf to a wide range of soils. Sow 8 to 10 pounds per acre.

\section{ALTA FESCUE}

\section{(Festuca elatior arundinacea)}

Alta Fescue is an outstanding grass of recent development for both pasture and hay purposes. It is much more productive than Meadow Fescue, It grows late in the summer and fall when other grasses have passed their productive peak. Various trials show it to outyield other varieties from 15 to 50 per cent. The dense root system, reaching a depth of 5 to 6 feet, nakes this variety valuable as a soil builder where the humus content is low. It also crowds out undesirable weed growth. Sow 12 to 15 pounds per acre.

\section{REED CANARY GRASS}

(Phalaris arundinacea)

This is a valuable, high-yielding forage plant that is naturally adapted to low wet lands. Two or three crops of high quality hay may be cut or it will provide excellent all summer pasture. Sow it at the rate of 5 to 6 pounds per acre broadcast or in drills, or 2 to 3 pounds per acre in 16 to 18 -inch rows.

\section{SUDAN GRASS (Common)}

Drill 15 to 20 pounds or broadcast 25 pounds per acre for pasture. It will tolerate alkali. Planted in rich soil in June, it will be ready to pasture in $\mathbf{3 0}$ days, furnishing grazing for two cows per acre throughout the summer. As a hay crop, it should be cut when heads appear. Allow several days of ideal weather to cure. A second crop may be cut or pastured, as preferred.

\section{RED TOP}

A valuable grass for wet and slightly alkaline soils. Sow 15 to 25 pounds per acre.

\section{NEW SWEET SUDAN GRASS}

This new variety is sweet, juicy and more palatable to livestock. Sweet Sudan is later in maturity than Common Sudan, thereby producing more vegetative growth and remaining green longer than the Common. After the crop reaches maturity the stalks and stems are still eaten readily. Sweet Sudan has more and broader leaves, heavier and taller stalks, and stools much heavier than Common Sudan.

\section{TALL MEADOW OAT GRASS}

Tall Meadow Oat is a deep-rooted, drought-resistant perennial grass. It produces an abundance of very palatable forage from early spring until late fall. Recent pasture grass experiments conducted by U.S.A.C. at Logan prove this grass to be one of the most desirable from the standpoint of productivity and palatability. Tall Meadow Oat Grass gives best results for pasture when sown in a mixture with other grasses and clover.

\section{TUALATIN OAT GRASS (Groated Seed)}

Tualatin Oat Grass possesses the same growth habits, adaptabilities and forage value as Tall Meadow Oat Grass. However, the seed kernel of this new strain has been mechanically removed from the large bulky hull by a process known as groating. The removal of the hull allows trouble-free drilling of the seed and greatly reduces the bulk of seed to be handled.

\section{TIMOTHY}

Of hay grasses, Timothy leads all. Thrives on clay or heavy loams, wet or boggy soils, or in mountainous districts. Alone, sow 12 pounds to the acre, or with clover, 10 pounds Timothy and 6 pounds clover.

\section{Other FORAGE and COVER CROPS}

\section{MILLET}

2894 Yellow Hog. Mainly a grain crop but the hay is of a good quality for feeding purposes.

\section{SUNFLOWER}

2930 Grey Stripe. A good silage crop for dry land. Very palatable and has high food value. Plant 5 to 6 pounds per acre.

\section{DRY-LAND GRAIN SORGHUMS}

2920 60-Day Milo (Dwarf or Combine Strain). Similar to Kaffir Corn but shorter. Grows erect, with thick, close-jointed stalks 2 to 3 feet tall. The large heads give a heavy yield of grain. It is drought-resistant and does well on alkaline soils.

\section{SWEET SORGHUMS}

2928 Black Amber Cane. 90 to 110 days. Tall-growing, excellent silage variety. Short supply this year. Ask about prices and a vailability.

\section{FIELD PEAS}

2880 Canadlan Fleld. They enrich the soil and are splendid stock feed. For hay, they should be cut while the milk is in the vine forming the pod. Plant early in the spring at the rate of 100 to 120 pounds per acre or 60 pounds with a nurse crop of oats or spring rye.

\section{KOCHIA}

2916 Scoparia. Grows 4 to 5 feet tall and yields 5 to 7 tons of hay per acre when under irrigation. On alkaline soil it is equally productive. The hay contains 4 to 8 per cent more protein than alfalfa.

Kochia is a drought-resistant forage plant adapted to dry land planting. Sow seed at the rate of 6 pounds per acre on irrigated land or 3 pounds per acre on dry land in late fall or early spring.

\section{VETCH}

2940 Common. Grown as a hay and seed crop, as well as for green manure, silage, and pasturage. Sow 60 to 80 pounds per acre.

\section{About Prices}

All field seed prices are quoted on page S-8.

The prices quoted hereln are subject to market changes. You are safe, however, In sending remlttance according to these prices. In case of decllne, the difference will be promptly refunded; if there has been an advance, you will be notified for your confirmation before shipment is made. 


\section{FIELD SEED PRICES}

IMPORTANT: All field seed prices are subject to market changes. You are safe, however, in sending remittance based on these prices. In case of decline, the difference will be promptly refunded; when an advance has been necessary, you will be notified for your confirmation before shipment is made.

For 5 to 9 pounds add $1 \mathrm{c}$ per pound to the 10-pound rate.

For 1 to 4 pounds add 3c per pound to the 10-pound rate.

FIELD CORN HYBRIDS

5 to 910 to 551 to 910 bus
Ibs. lbs. bus. up.
per Ib.per lb. per bus. per
bus.

2505 Port-Walco No. $90 \ldots \ldots \ldots \ldots$. Write for our early spring 2502 Port-Walco No. 100......... farm seed price list for

2507 Port-Walco No. $120 \ldots \ldots \ldots$....

\section{FIELD CORN (Open-Pollinated)}

10 to 2425 to 991 to 910 bags

lbs. lbs. bags per

per Ib. per Ib. per cwt. cwt.

2512 Minnesota No. 13.......... \$0 $15 \quad \$ 0 \quad 14 \quad \$ 13 \quad 00 \quad \$ 1275$

\section{GRASS SEEDS-Pasture and Dry Land \\ 10 to 2425 to 99 Bag Ibs. Ibs. lots per lb. per Ib. per 100}

2710 Brome Grass (Smooth) ...........\$0 33

2700 Mountain Brome Grass............ 32

2740 Meadow Fescue, Fancy............ 31

2735 Alta Fescue, Blue Tag............. 47

2750 Orchard Grass, Fancy.............. 39

2840 Reed Canary Grass............... 54

2760 Rye Grass, Perennial Blue Tag........ 23

2830 Red Top, 92\% Pure............. 65

2810 Slender Wheat Grass.............. 57

2788 Intermediate Wheat Grass Cert...... 65

2786 Intermediate Wheat Grass Uncertifred . 62

2793 Tall Wheat Grass................. 47

2934 Sudan Grass, Fancy............... 24

2935 New Sweet Sudan Grass............ 26

2850 Tall Meadow Oat Grass........... 54

2851 Tulatin Oat Grass (Groated Seed) Cert. 71

2853 Tualatin Oat Grass (Groated Seed).... 66

2860 Timothy, $99.50 \%$ Pure............ 30

2780 Crested Wheat Grass.............. 58

$\$ 032$
31
30
46
38
53
22
64
56
64
61
46
23
25
53
70
65
29

Ibs.

$\$ 3100$

3000

2900

4500

3700

5200

2100

6300

5500

6300

6000

4500

2200

2400

5200

6900

6400

2800

5600

\section{ALFALFA SEED}

10 to 2425 to 99 Bag

lbs. Ibs. lots

per Ib. per lb. per 100

lbs.

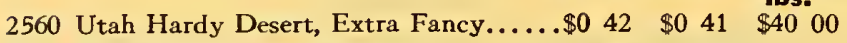

2563 Utah Hardy Desert, Fancy......... 40 $39 \quad 3800$

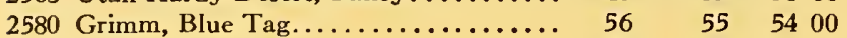

2590 Ladak, Blue Tag................ 56 $56 \quad 55 \quad 5400$

2578 Ranger, Utah Certified.................................... $57 \quad 5600$

2577 Ranger Utah Uncertifred ........... $47 \quad 46 \quad 4500$

\section{CLOVERS}

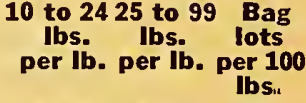

2600 Alsike, 99\% Pure................\$0 45 \$0 $44 \$ 4300$ 2620 Ladino Certified.................. $142 \quad 141 \quad 14000$ 2621 Ladino Uncertifred................ $117 \quad 1 \quad 16 \quad 11500$ 2630 Red Clover, Medium.............. $49 \quad 48 \quad 4700$ 2640 Strawberry................... $227 \quad 226 \quad 22500$ 2660 Sweet White Blossom.............. 20 $19 \quad 1800$ 2666 Sweet Yellow Blossom............. 20 $19 \quad 1800$ 2610 Hubam, Annual................ $24 \quad 23 \quad 2200$

\section{P.-W.'s PASTURE MIXTURES}

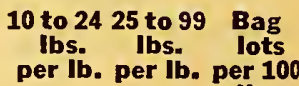

2670 (A) For Well-Drained Irrigated Land or

Damp Fertile Soils................. \$0 $53 \$ \$ 0 \quad 52 \quad \$ 5100$ 2676 (B) For Alkaline and Wet Soils..... $52 \quad 51 \quad 5000$

\section{OTHER FARM SEED}

2880 Canadian Field Peas, Extra Fancy..... \$0 16 \$0 $15 \$ \$ 1400$ 2916 Kochia Scoparia................. $80 \quad 79 \quad 7800$ 2894 Millet, Yellow Hog, Large Millet..... $14 \quad 13 \quad 1200$ 2920 Milo Maize, 60-Day............. 141/2 131/2 1250 2928 Sorghum, Black Amber Cane.......... Ask for prices 2930 Sunflower, Grey Stripe........... $32 \quad 31 \quad 3000$ 2940 Vetch, Common or Spring........... $16 \quad 15 \quad 1400$

\section{MANGELS}

87 CORONA. An improved giant half

$$
\begin{aligned}
& 1 \text { to } 45 \text { to } 2425 \text { to } 99100 \\
& \text { lbs. Ibs. lbs. Ibs. } \\
& \text { per lb. per lb. per lb. per lb. }
\end{aligned}
$$

sugar mangel with the yielding ability

of Sludstrup and higher quality.....\$0 $65 \quad \$ 0 \quad 55 \quad \$ 0 \quad 50 \quad \$ 045$

\section{NOTICE}

Field seed prices are quoted subject to market fluctuations which result in frequent changes.

If your remittance is more than the market price the difference will be refunded.

In case of an advance your confirmation will be solicited before shipment is made.

\section{MULTIFLORA ROSE}

A Permanent Low-Cost Fence. Requires No Maintenance.

Fast Growing. Makes a dense, stock-tight fence in three to frve years.

Eliminates Fence Line Weeds.

Does Not Spread. Multiflora Roses do not sucker.

Requires No Maintenance. Eliminates fence repairing costs. Needs no clipping, pruning or training. Just irrigate during the first year to get the new plants established, and keep the weeds down for two years.

Set plants 18 inches apart in fall or early spring.
Prices per plant F. O. B. Salt Lake City

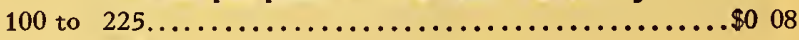

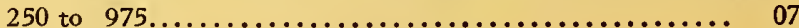

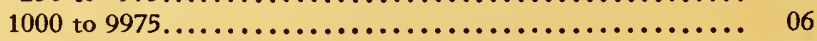

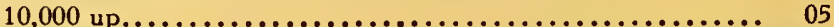

Shipping weight approximately 50 Ibs. per 1000. 


\section{Flawering}

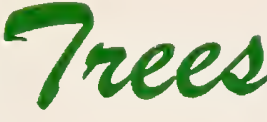

BIRCH, continued

9540 Cutleaf Weeping (Pendula gracilis). White branches with hanging, slender stems and deeply cut leaves. Very beautiful, hardy and clean. Plant very early to insure a good start. Special handling makes these trees available for February planting. The trunks of smooth-barked trees like Birch should be wrapped for the first year after planting.

7 to $8 \mathrm{ft} ., \$ 5.00$ each; 3 for $\$ 14.25$.

8 to $10 \mathrm{ft}$. $\$ 6.00$ each. 3 for $\$ 16.95$

9543 Birch Clumps, European White. H 35. Especially useful for naturalistic effects.

5 to $6 \mathrm{ft}$., $\$ 4.00$ each; 3 for $\$ 11.25$.

6 to $8 \mathrm{ft}, \$ 4.50$ each; 3 for $\$ 12.75$.

8 to $10 \mathrm{ft} ., \$ 5.00$ each; 3 for $\$ 14.25$

\section{FLOWERING CHERRY. Prunus}

9660 Kwanzan. H 25. One of the most beautiful spring-flowering trees, in late April almost completely covered with double bright pink flowers. Hardy in all except extremely cold sections. 3 to $4 \mathrm{ft}$., $\$ 2.50$ each; 3 for $\$ 6.90$.

5 to $6 \mathrm{ft}$., $\$ 3.50$ each; 3 for $\$ 9.75$.

\section{FLOWERING CRABAPPLE • Malus}

Because of their excellent growing habits, foliage, flowers and fruits, the Flowering Crabapples are among the best-loved small trees. Very hardy.

9565 Bechtel's. H 12. A very symmetrically formed tree with large, double pink flowers.

2 to $3 \mathrm{ft}$., $\$ 1.50$ each; 3 for $\$ 4.20$.

3 to $4 \mathrm{ft}$., $\$ 2.00$ each; 3 for $\$ 5.70$

9568 Eleyi. H 15. A mass of red bloom. Dark red fruit that makes fine jelly. 5 to $6 \mathrm{ft}, \$ 3.00$ each: 3 for $\$ 8.40$

9574 Hopa. H 12. A gorgeous mass of soft rose-red, single flowers. The tree is upright and uniform in habit. 5 to $6 \mathrm{ft}$., $\$ 3.00$ each; 3 for $\$ 8.40$

\section{ELM . Ulmus}

9584 Chinese (Parvifolia). H 40. Open-headed tree with small, firm leaves, shining above and smooth underneath.

5 to $6 \mathrm{ft}$., $\$ 1.50$ each; 3 for $\$ 4.20$

6 to $8 \mathrm{ft}$., $\$ 2.50$ each; 3 for $\$ 6.90$.

8 to $10 \mathrm{ft}$., $\$ 3.00$ each; 3 for $\$ 8.40$

10 to $12 \mathrm{ft}$., $\$ 4.00$ each; 3 for $\$ 11.25$.

9592 Moline. H 75. Columnar form. Older specimens are more

6 to $8 \mathrm{ft}$. $\$ 3.50$ each; 3 for $\$ 9.75$

8 to $10 \mathrm{ft}$., $\$ 4.50$ each; 3 for $\$ 12.75$

\section{GOLDEN-CHAIN - Laburnum Vossi}

9602 A small tree with flowers of pure golden yellow in 18-inch clusters. 4 to $6 \mathrm{ft}$., $\$ 3.75$ each; 3 for $\$ 10.50$.

\section{FLOWERING HAWTHORN (Crataegus)}

9600 Paul's Double Scarlet. H 15. Crimson-scarlet flowers followed by large red berries. Bloons in late May. 6 to $7 \mathrm{ft}$. $\$ 4.50$ each; 3 for $\$ 12.75$.

9597 Autumn Glory. H 15-20. A medium-sized tree with a shapely head and deep green foliage. Big clusters of white blooms; in early autumn its clusters of giant berries turn to brilliant red. 6 to $8 \mathrm{ft}$., $\$ 5.00$ each; 3 for $\$ 14.25$.

\section{LOCUST}

9615 Moraine (Gleditsia). Pat. 836. H 75. An outstanding new shade tree. Hardy, disease free and a rapid grower. The tough hardwood branches arch upward and outward to form a broad-topped, vase-shaped tree of stately beauty. There are no objectionable seed pods and its roots do not interfere with smaller plants. 8 to $9 \mathrm{ft}$., $\$ 8.00$ each; 3 for $\$ 22.50$.

9608 Black (Robinia Pseudoacacia). H 50. Fast growing and sturdy. Very useful for background planting and windbreaks. Clusters of fragrant white flowers in June. 8 to $10 \mathrm{ft}$., $\$ 2.50$ each; 3 for $\$ 6.90$.

\section{MAPLE - Acer}

9624 Norway (Platanoides). H 60. A thrifty, clean, hardy species adaptable to almost any soil or climate. An ideal street tree, enduring city life well. 3-yr.-old unbranched, 8 to $9 \mathrm{ft}$., $\$ 2.50$ each; 3 for $\$ 6.90$.

6 to $8 \mathrm{ft}$. branched, $\$ 4.00$ each; 3 for $\$ 11.25$.

8 to $10 \mathrm{ft}$. branched, $\$ 4.75$ each. 3 for $\$ 13.50$.

9626 Schwedleri (Platanoides Schwedleri). H 60. Red and purple foliage in spring, turning golden yellow in autumn. Same habit of growth as Norway Maple. 6 to $8 \mathrm{ft}$. branched, $\$ 5.00$ each; 3 for $\$ 14.25$.
NATURE'S OWN AIR-CONDITIONERS . ". THE FIRST ESSENTIAL FOR LANDSCAPING THE HOME

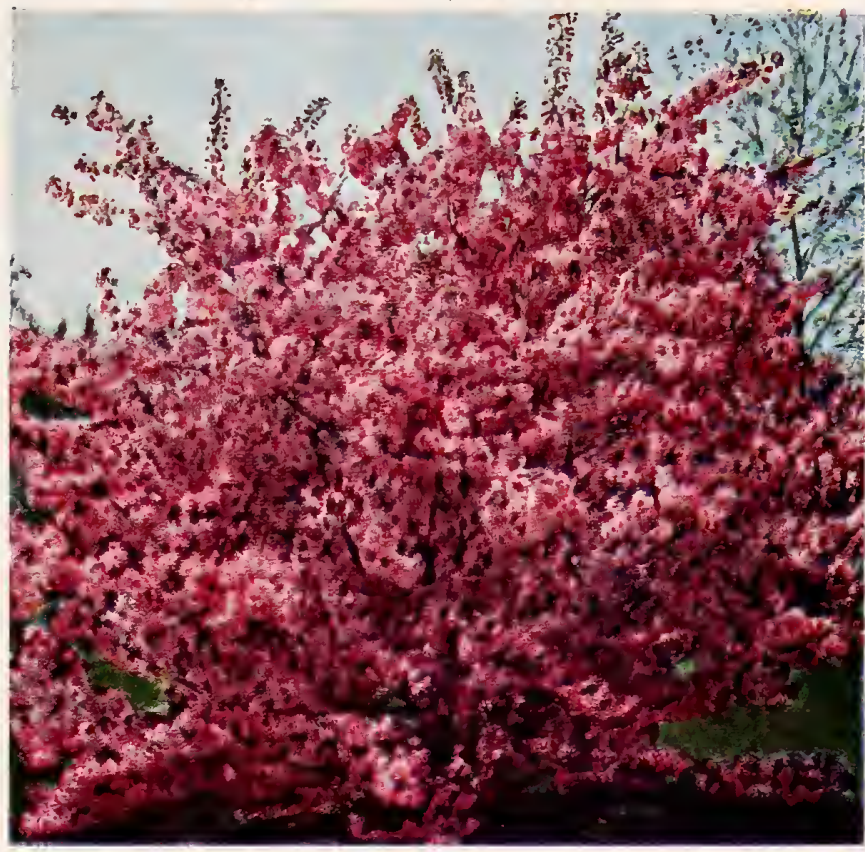

FLOWERING CRABAPPLE

MAPLE - Acer, continued

9629 Amur (Ginnala). H 20. A graceful and interesting small tree, dense and bushy. Foliage is Iustrous green in summer, turning to brilliant red in autumn. Fragrant creamcolored blooms in May and conspicuous red seed clusters throughout the summer keep Amur Maple constantly attractive. Very hardy. 4 to $5 \mathrm{ft}$., $\$ 1.25$ each; 3 for $\$ 3.45$.

9623 Crimson King. Pat. 735. Superb for lawns, street planting or specimens. Its large, richer purple leaves retain their color all summer. Perfectly hardy. 7 to $8 \mathrm{ft}$. unbranched, $\$ 7.00$ each.

\section{MAY DAY TREE}

9680 Prunus padus commutata. H 15-20. Beautiful flowering tree for the average yard. Although still quite rare in this area it is extremely hardy and always blooms about the first of May. Sweetly fragrant, $1 / 2$-inch flowers in long racemes. In the summer the shiny black cherry-like fruits are relished by the birds. May be trimmed for a street or lawn tree or allowed to grow in bush form. 5 to $6 \mathrm{ft}$., $\$ 3.50$ each; 3 for $\$ 9.75$.

\section{MULBERRY . Morus}

9634 Russian (Tatarica). H 25. Another quick grower. The tree is of moderate size, hardy and very resistant to wind or snow breakage.

5 to $6 \mathrm{ft}$., $\$ 2.00$ each; 3 for $\$ 5.70$.

6 to $8 \mathrm{ft}$., $\$ 2.50$ each; 3 for $\$ 6.90$.

9636 Fruitless (Kingan). H 25. A clean, fast-growing tree with large leaves. 8 to $10 \mathrm{ft}$., $\$ 3.50 ; 3$ for $\$ 9.75$.

\section{PEACH, FLOWERING. Amygdalus persica}

\section{Helen Borchers. H 15 . Double pink flowers of large} size, borne in great profusion. A rapid grower of upright form. 3 to $4 \mathrm{ft}$., $\$ 1.50$ each; 3 for $\$ 4.20$

4 to $6 \mathrm{ft} \$ 2.00$ each. 3 for $\$ 5.70$

9644 Double Red. H 15. Similar to above but produces bright red blooms.

3 to $4 \mathrm{ft}$., $\$ 1.50$ each; 3 for $\$ 4.20$

4 to $6 \mathrm{ft}$., $\$ 2.00$ each; 3 for $\$ 5.70$.

\section{PLANE-TREE • Platanus}

9646 Acerifolia London Plane-tree H 70 . Forms a fine, spreading, well-rounded head. Leaves are large and deeply lobed.

6 to $8 \mathrm{ft}$., $\$ 3.50$ each; 3 for $\$ 9.75$.

8 to $10 \mathrm{ft}$., $\$ 4.00$ each; 3 for $\$ 11.25$.

10 to $12 \mathrm{ft}$., $\$ 5.00$ each; 3 for $\$ 14.25$.

\section{FLOWERING PLUM. Prunus}

9678 Double Triloba. See under shrubs, page 13

$\$ 676$ Thundercloud. The best and darkest foliage of all the purple-leaved Flowering Plums. Single, light pink flowers.

3 to $4 \mathrm{ft}$., $\$ 1.50$ each; 3 for $\$ 4.20$.

4 to $5 \mathrm{ft}$., $\$ 2.00$ each; 3 for $\$ 5.70$ 


\section{Flawering 7reed, continued}

\section{POPLAR . Populus}

9650 Bolleana. H 60. A tall, columnar tree. Silvery foliage.

8 to $10 \mathrm{ft}$., $\$ 4.00$ each; 3 for $\$ 11.25$.

10 to $12 \mathrm{ft}$., $\$ 4.50$ each; 3 for $\$ 12.75$.

9654 Carolina (Canadensis). H 50. Branching habit.

9656 Lombardy (Nigra italica). H 80. Narrow and columnar.

Price of Carolina and Lombardy poplars.

6 to $8 \mathrm{ft}$., $\$ 1.50$ each; 3 for $\$ 4.20$.

8 to $10 \mathrm{ft}, \$ 2.00$ each; 3 for $\$ 5.70$

10 to $12 \mathrm{ft} ., \$ 3.50$ each; 3 for $\$ 9.75$.

\section{REDBUD - Cercis}

9562 Canadensis. H 30. Striking, ornamental trees with peashaped, pink flowers in early spring before the leaves appear. 4 to $6 \mathrm{ft}$., $\$ 2.50$ each; 3 for $\$ 6.90$.

\section{RUSSIAN OLIVE}

9638 Elaeagnus angustifolia. H 20. Silvery green foliage. Very hardy and vigorous. Valuable for screens, hedges and as a color accent.

5 to $6 \mathrm{ft}$., $\$ 2.50$ each; 3 for $\$ 6.90$

6 to $8 \mathrm{ft}$., $\$ 3.50$ each; 3 for $\$ 9.75$.

18 to 24 -in. seedlings for hedging and windbreaks. 25 for $\$ 3.25$; 50 for $\$ 5.50 ; 100$ for $\$ 10.00$

\section{Sophora japonica CHINESE SCHOLAR-TREE}

$9684 \mathrm{H} 60$. A symmetrical, round-headed tree with glossy, dark green foliage. Cream-colored panicles of bloom in late July. 5 to $6 \mathrm{ft}$., $\$ 3.50$ each; 3 for $\$ 9.75$.

6 to $8 \mathrm{ft} ., \$ 4.00$ each; 3 for $\$ 11.25$.

\section{WILLOW - Salix}

9690 Weeping Babylonian. H 30. One of our most charming trees. Weeping Willows have long been admired for their graceful appearance and rapid growth. Green branches.

6 to $8 \mathrm{ft}$., $\$ 3.00$ each; 3 for $\$ 8.40$.

8 to $10 \mathrm{ft}$., $\$ 3.50$ each; 3 for $\$ 9.75$

10 to $12 \mathrm{ft}$., $\$ 4.00$ each; 3 for $\$ 11.25$.

9698 Weeping Golden. H 25-30. Similar to Babylonian Willow but has golden yellow bark, which produces interesting effect in winter and early spring.

6 to $8 \mathrm{ft}$., $\$ 3.00$ each; 3 for $\$ 8.40$.

8 to $10 \mathrm{ft}$., $\$ 3.50$ each; 3 for $\$ 9.75$.

\section{Nut 7rees}

Every farmer, orchardist, berry grower, poultryman and home owner should make use of this group of fine productive trees. Both as a welcome supplement to the home orchard and for their la ndscape value, they have gained favorable recognition in many rural and city properties.

\section{ALMONDS \\ Beautiful and Fruitful}

AImonds can be grown any place where peaches and sweet cherries are successfully produced. They prefer light sandy loam and good drainage but will thrive on most average garden soils. Both varieties must be planted together to insure good pollination and high production.

9716 Northern. H 20. Exceptionally hardy and productive, bearing soft-shelled nuts of excellent quality.

9720 Utah I.X.L. H 20. Smooth, soft-shelled nuts of fine flavor. Almonds prefer a light, well-drained soil.

Either of above

3 to $4 \mathrm{ft}$., $\$ 2.00 \mathrm{each} ; 3$ for $\$ 5.70$.

4 to $6 \mathrm{ft}$., $\$ 2.50$ each; 3 for $\$ 6.90$.

\section{WALNUTS}

9728 English. H 50. Hardy strain. Makes a fine shade tree for the back yard. 6 to $8 \mathrm{ft}$. $\$ 4.00$ each; 3 for $\$ 11.25$.

$\rightarrow 9732$ Improved Thomas Black. H 80 . Large nuts with large kernels which come out in halves. Has a distinctive flavor. The tree is fast growing, upright, and begins bearing in five years. 5 to $6 \mathrm{ft}$., $\$ 3.50$ each; 3 for $\$ 9.75$.
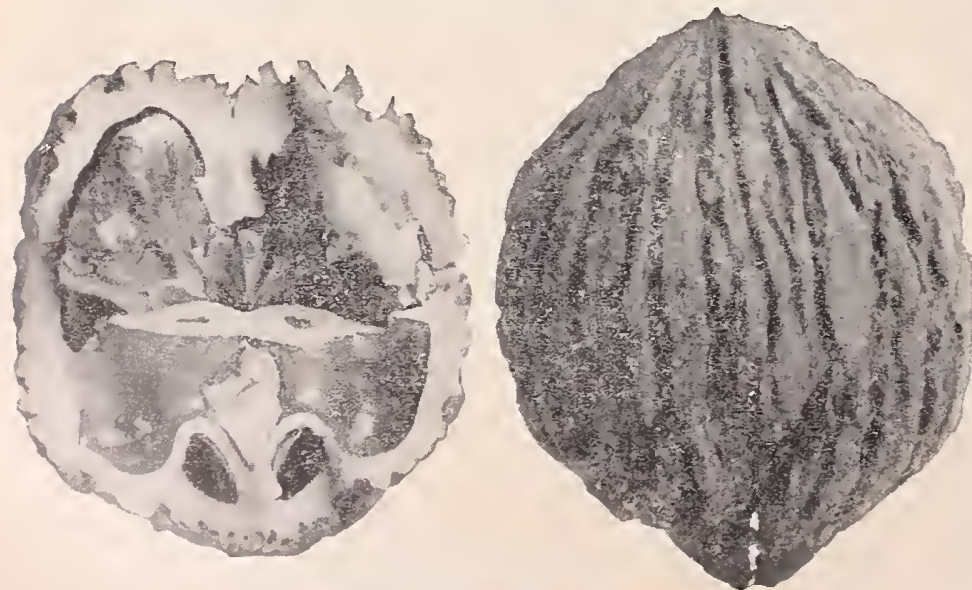

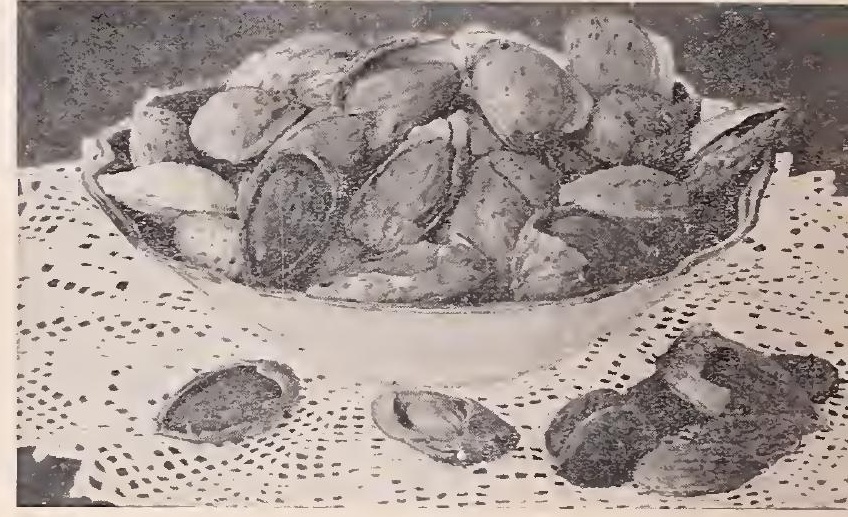

ALMONDS

\section{6-in-one APPLE TREE}

Six different kinds on one tree. Here are six of our best Apples specially grafted onto a single tree which will provide you with delicious fruit from early summer to late winter.

Yellow Transparent. For summer.

Wealthy. For fall.

Delicious Yellow Gold. For Iate fall.

Delicious Solid Red. For early winter.

Jonathan Solid Red. For midwinter.

Winesap Solid Red. For late winter.

Now, even the gardener with a small yard can enjoy several different kinds of Apples over the entire Apple season from just one tree. From the first spring flowers to the end of the harvest season, 6-in-1 Apple tree is an interesting and attractive part of the landscape. 9739 Heavy $5 \mathrm{ft}$., $\$ 3.00$ each.

\section{MAIL ORDER INFORMATION}

All fruit trees are priced f.o.b. Salt Lake City. Please include an additional amount for packing and postage according to the following table:

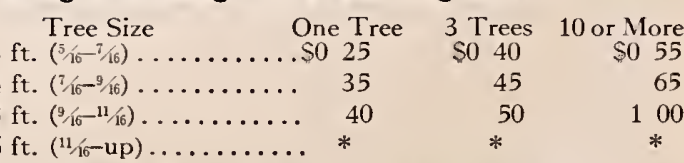

*Express or motor freight is recommended for 6-foot trees and for larger quantities of all other sizes. 


\section{P.-W.'s FRUIT TREES \\ Manntain Gromen for Greater Productivity}

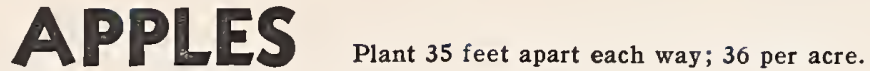

\section{Summer Varieties}

9750 Early Redbird. Claimed to be the earliest red Apple in cultivation. Ripens a week earlier than Yellow Transparent. Because of its large size, excellent flavor and cooking qualities, it is superseding the old favorite, Red Astrachan.

9757 Summer Delicicus. Similar to Red Delicious in size, shape, color and flavor, but it ripens in July and August. An exceptional home orchard or early market Apple.

$\triangle 9756$ Yellow Transparent. One of the earliest. Pale yellow when ripe; good quality. Ripens in July.

\section{Autumn Variety}

19746 Wealthy. Dark red, sub-acid. Trees bear very young.

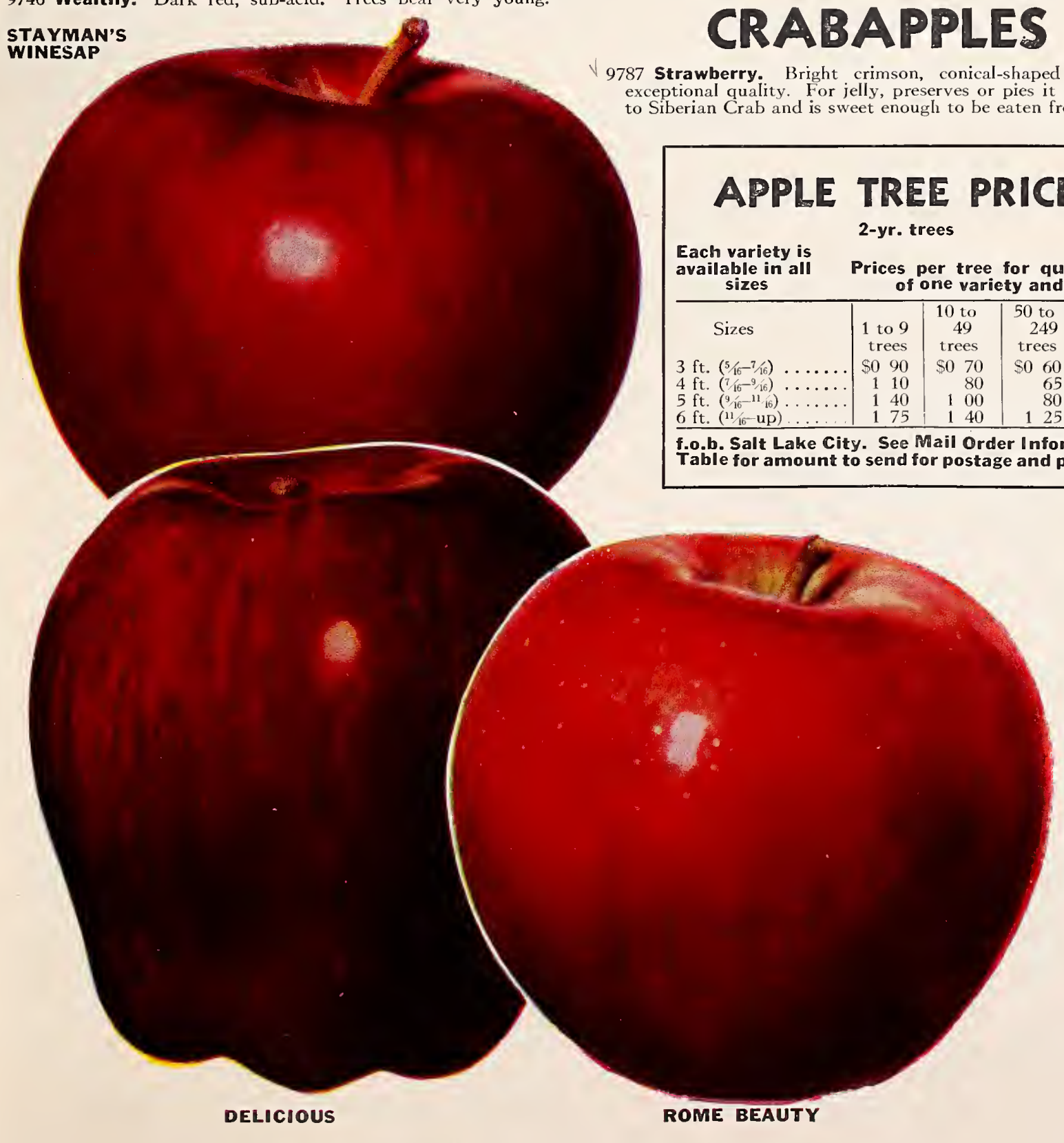

9762 Delicious. Solid red. Most popular for eating, storing and shipping.

1) 9764 Delicious, Yellow-gold. It bears young and heavily. The fruit is large and juicy. No other yellow Apple is of better quality.

9766 Sonathan. Solid red. Equal to Dclicious in popularity. Very firm, richly flavored flesh.

9772 Rome Beauty. Solid red. A brilliant red Apple, Iarge, tender, juicy. The tree is hardy and bears heavy crops every year.

9774 Stayman's Winesap. Smooth, greenish yellow, splashed and striped with red and purple. exceptional quality. For jelly, preserves or pies it is superior to Siberian Crab and is sweet enough to be eaten fresh.

\section{CRABAPPLES}




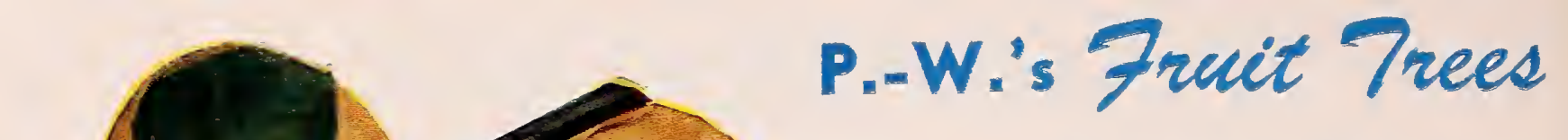

\section{"Mountain Grown"}

\section{for Greater}

\section{Productivity}

\section{SWEET CHERRIES}

Plant 30 feet apart; 49 per acre

9800 Bing. About one week earlier than Lambert. One of the best market Cherries. Large, dark red, nearly black. Meat firm, sweet, and exceedingly well flavored. Ripens in July in Salt Lake valley. A wonderful shipper.

9790 APRICOTS, Chinese

\section{APRICOTS}

Plant about 25 feet apart each way

9790 Chinese. Large, round, deep orange-colored fruits. Because this Apricot retains its firmness when shipped, it is the leader for commercial orchard planting. Extra rich flavor and color, together with its sweet nut-like pit, are qualities desired by the majority for home use. Chinese Apricot is very productive, usually beginning to bear the third year after planting. Ripenslate June.

9796 Moorpark. Very Iarge, light yellow, oval-shaped fruit. The tree is slightly hardier than Chinese. Late June.

\section{APRICOT PRICES}

Each variety available in all sizes

\begin{tabular}{|c|c|c|c|}
\hline in all sizes & \multicolumn{3}{|c|}{ of one variety and size } \\
\hline Sizes & 1 to 9 & 10 to 49 & 50 to 249 \\
\hline $3 \mathrm{ft} .\left(5 / 16^{-7} / 16\right)$ & $\$ 090$ & $\$ 070$ & S0 60 \\
\hline $4 \mathrm{ft} \cdot\left(7 / 16^{-9} / 16\right)$ & 110 & 80 & 65 \\
\hline $5 \mathrm{ft} .(9 / 16-11 / 16)$. & 140 & 100 & 80 \\
\hline $6 \mathrm{ft} .(11 / 16-\mathrm{up})$ & 175 & 140 & 125 \\
\hline
\end{tabular}

\section{PEACHES}

Plant 20 to 25 feet apart each way; 70 to 108 per acre 9828 Early Elberta. About ten days earlier than regular Elberta. Has sweeter flesh.

9826 Elberta. A leading market variety. Large, handsome, bright yellow overspread with crimson; juicy. Fine shipper. Freestone.

-9833 Hale Elberta. One of the largest fruiting Peaches grown and one of the most beautifully colored. The flesh is firm, solid and delicious. Freestone. Ripens four days later than J. H. Hale.

9836 Hale Haven. Large, reddish yellow. A cross between J. H. Hale and South Haven, combining the good qualities of both. Ripens 17 days before Elberta.

-9834 J. H. Hale. Large, orange-yellow. Considered by many to be superior to Elberta. Freestone.

9840 Orange Cling. Very large. Yellow with dark crimson cheek; flesh golden yellow.

9837 Red Haven. Best of the extra early Peaches and the earliest yellow freestone. The fruit is highly colored, smooth and almost fuzzless. Red Haven is a heavy cropper, ripening the first week in August.

9831 Summer Elberta. A new, superior, very early, yellowfleshed freestone Peach. Sweet, juicy flesh and beautiful red skin. Excellent for canning, shipping and for eating fresh. Ripens in early August.

\section{NECTARINES}

The Nectarine has a smooth skin like a plum. Its juicy green flesh has a fresh, distinctive flavor. Set trees 16 to 18 feet apart. 9816 John Rivers. The hardiest Nectarine. Attractive size, red cheek and Iuscious green flesh.

9802 Lambert. Follows Bing in ripening and is fully equal to it as a commercial and home variety. Fruit very large, heart-shaped; firm flesh of rich, sweet flavor. It is less subject to frost injury in blossom time than any other sweet variety. Ripens in July.

9804 Black Tartarian. Large, purplish black, sweet. Ripens first of July. Plant witb Bing or Lambert for pollination.

\section{SOUR CHERRIES}

Plant 20 feet apart each way; 108 per acre.

9812 Montmorency Improved. This strain produces much larger fruit than the old true Montmorency and has become the leading sour Cherry for cold pack and canning. Ripens late June to earIy July.

\section{HANSEN'S BUSH CHERRIES}

9214 Hardy, easy to grow, and early bearing, they adapt themselves to even the coldest climates. The fruit is good to eat fresh and makes delicious preserves. When used as ornamental shrubs they are beautiful as specimens, groups or hedges. 2 to $3 \mathrm{ft}$., $\$ 1.25$ each; 3 for $\$ 3.45 ; 10$ to 29 , \$1.10 each.

\section{PRICE SCHEDULE ON CHERRY TREES}

Each variety is available in all sizes

\begin{tabular}{|c|c|c|c|}
\hline Sizes & $\begin{array}{l}1 \text { to } 9 \\
\text { trees }\end{array}$ & $\begin{array}{c}10 \text { to } 49 \\
\text { trees }\end{array}$ & $\begin{array}{c}50 \text { to } 249 \\
\text { trees }\end{array}$ \\
\hline $3 \mathrm{ft} .(5 / 16-7 / 16)$ & \$1 25 & $\$ 105$ & \$0 90 \\
\hline $4 \mathrm{ft} .\left(7 / 16^{-9} / 16\right) \ldots \ldots \ldots \ldots \ldots$ & 150 & 120 & 100 \\
\hline $5 \mathrm{ft} .\left({ }^{9}(16-11 / 16) \ldots \ldots \ldots \ldots\right.$ & 175 & 140 & 125 \\
\hline $6 \mathrm{ft} .\left({ }^{11} 16-\mathrm{up}\right) \ldots \ldots \ldots \ldots \ldots$ & 200 & 160 & 145 \\
\hline
\end{tabular}

\section{PLUMS and PRUNES}

Plant about 20 feet apart each way; 108 per acre

9873 Elephant Heart. Early strain. A huge, heart-shaped, freestone Plum with blood-red flesh and luscious flavor. Early September.

9872 Formosa. Early, Iarge, heart-shaped, cherry-red as it ripens, sweet and delicious. Early July.

9886 Santa Rosa. One of the leading shippers. Purplish red fruit of good size. Flesh reddish in color, juicy and delicious. Late July.

9890 Satsuma. A fine, Iarge purplish crimson Plum; pit small. Delicious flavor. Late August.

9898 ITALIAN FELLENBERG PRUNE. Large, oval, dark purple. Flesh greenish yellow, separating freely from stone; best for drying. August, September. Best commercial sort; on peach root. 


\section{Duarf Fruit 7rees}

Only a small space is required for these fruitful and ornamental Dwarf Trees Even a small yard can provide a wide variety of delicious fruit. Usually these trees begin bearing the first or second year after planting and are the most efficient way to use garden space.

Popular demand for Dwarf Fruit Trees has guided us in the selcction of this group of fine varieties, the largest we have ever offered.

Apple varieties in this group are on Malling No. 9 rootstock, which makes trees with 7 to 8 -foot spread

9793 Dwarf Apricot, Moorpark. (June.)

9814 Dwarf Cherry, Lambert. (July.)

9835 Dwarf Peach, Male Haven. (August.)

9869 Dwarf Pear, Bartlett. (September.)

9868 Dwarf Apple, Red Delicious. (October.)

9781 Dwarf Apple, Delicious Yellow Gold. (October.)

9784 Dwarf Apple, Early Red Bird. (JuIy.)

9783 Dwarf Apple, Rome Beauty. Solid red. (Late October.) Husky, 2-yr.-old trees, $\$ 3.00$ each

Include with your remittance $40 \mathrm{c}$ additional for one tree, $50 \mathrm{c}$, for 3 trees, $\$ 1.00$ for 10 trees for packing and postage.

\section{MINIMUM ORDERS}

No order will be accepted for less than $\$ 3.00$ unless accompanied by $25 \mathrm{c}$ additional service charge.
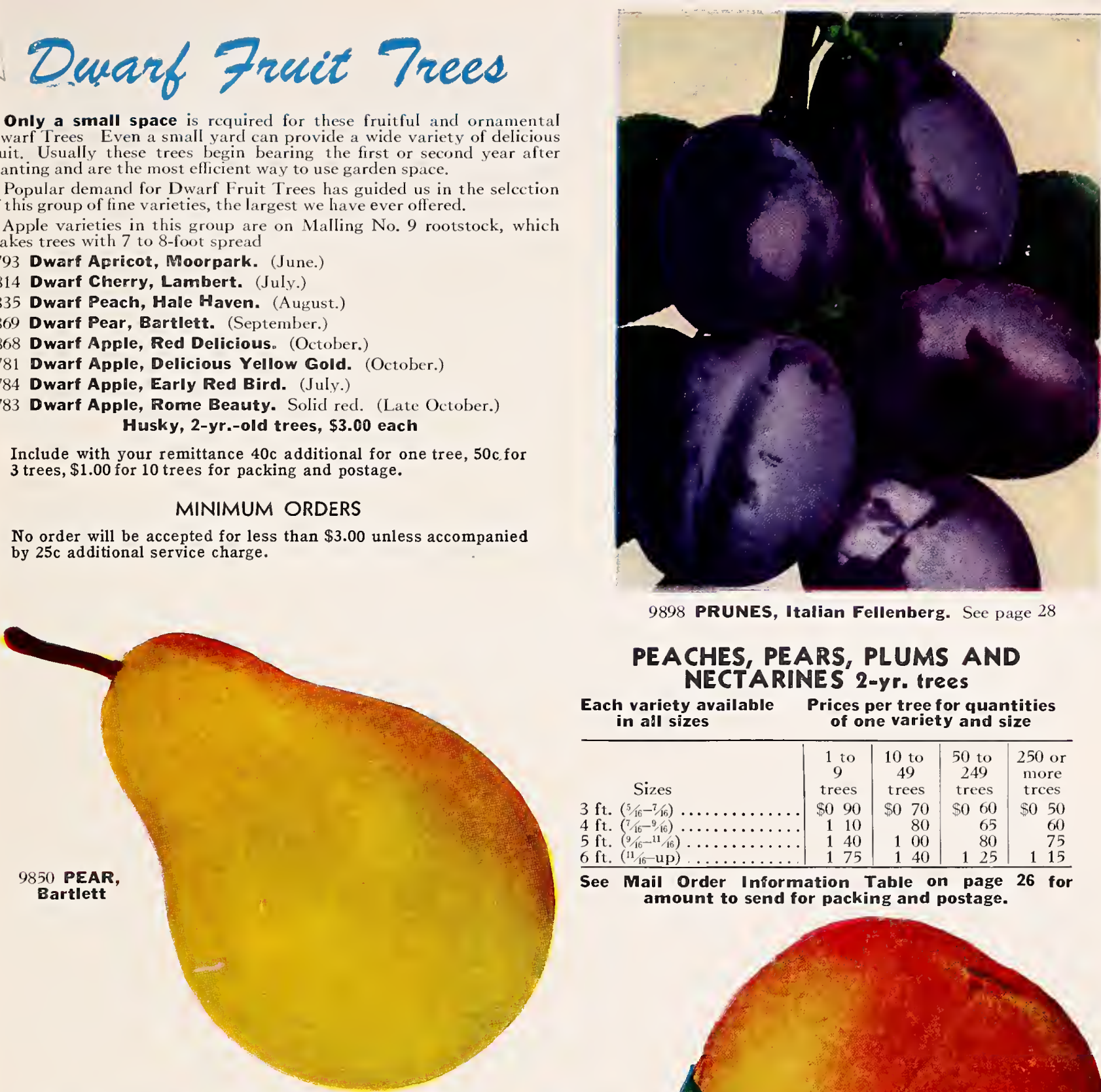

9898 PRUNES, Italian Fellenberg. See page 28

\section{PEACHES, PEARS, PLUMS AND NECTARINES 2-yr. trees}

\section{Each variety available Prices per tree for quantities} in all sizes of one variety and size

\begin{tabular}{|c|c|c|c|c|}
\hline Sizes & $\begin{array}{c}1 \text { to } \\
9 \\
\text { trees }\end{array}$ & $\begin{array}{c}10 \text { to } \\
49 \\
\text { trees }\end{array}$ & $\begin{array}{c}50 \text { to } \\
249 \\
\text { trees }\end{array}$ & $\begin{array}{c}250 \text { or } \\
\text { more } \\
\text { trees }\end{array}$ \\
\hline $3 \mathrm{ft} .\left(5 / 16^{7} / 16\right)$ & $\$ 090$ & so 70 & $\$ 060$ & $\$ 0 \quad 50$ \\
\hline $4 \mathrm{ft} .\left(7 / 16^{-9} / 16\right)$ & 110 & 80 & 65 & 60 \\
\hline $5 \mathrm{ft} .(9 / 16-11 / 16) \ldots$ & 140 & 100 & 80 & 75 \\
\hline $6 \mathrm{ft} .\left({ }^{11} / 16-\mathrm{up}\right)$ & 175 & 140 & 125 & 115 \\
\hline
\end{tabular}

See Mail Order Information Table on page 26 for amount to send for packing and postage.

\section{LUSCIOUS PEARS}

Plant about 20 feet apart each way

$\checkmark 9850$ Bartlett. Fruit large, clear, yellow highly flavored, very juicy. The best Pear for canning or eating fresh. September.

9854 Beurre d'Anjow. One of the best commercial winter Pears because of its long keeping qualities. The large greenish vellow fruits have delicious white flesh with a rich and vinous flavor. A good grower and prod ictive. Rip ens late October and $\mathrm{No}$ vember.

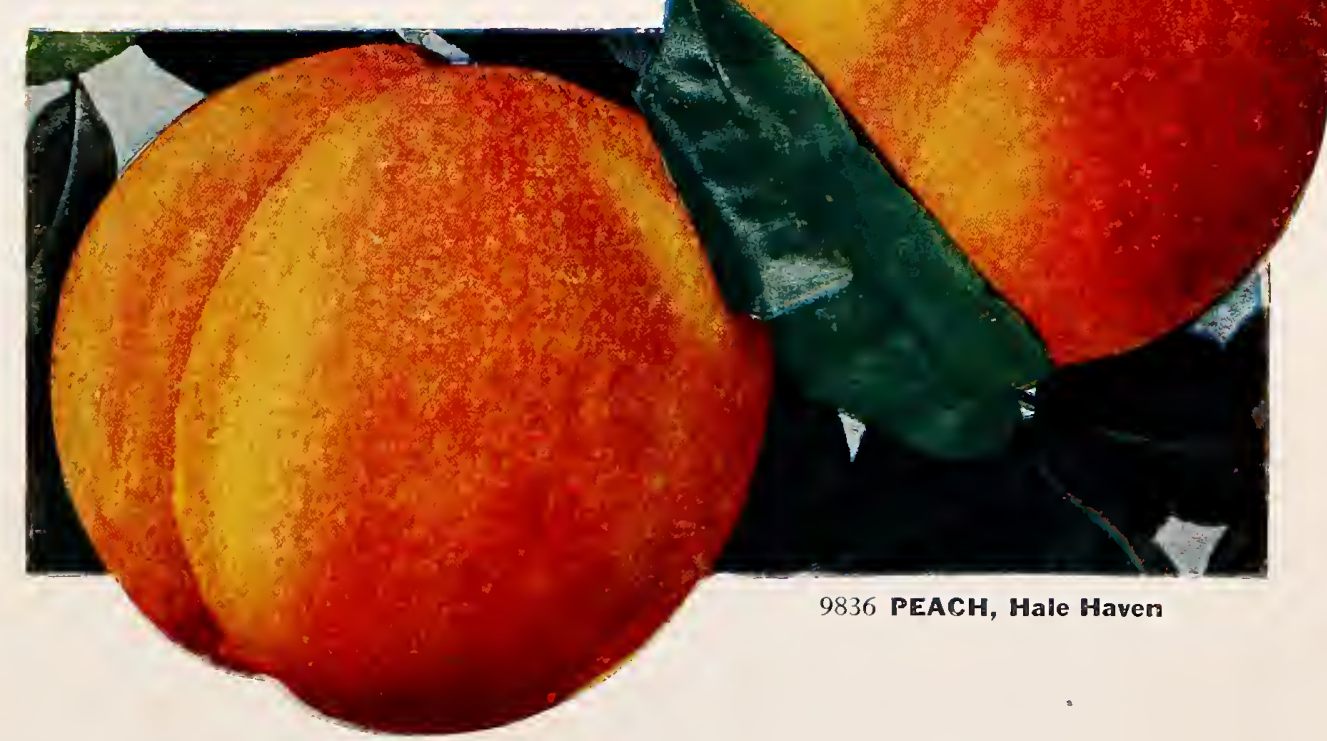




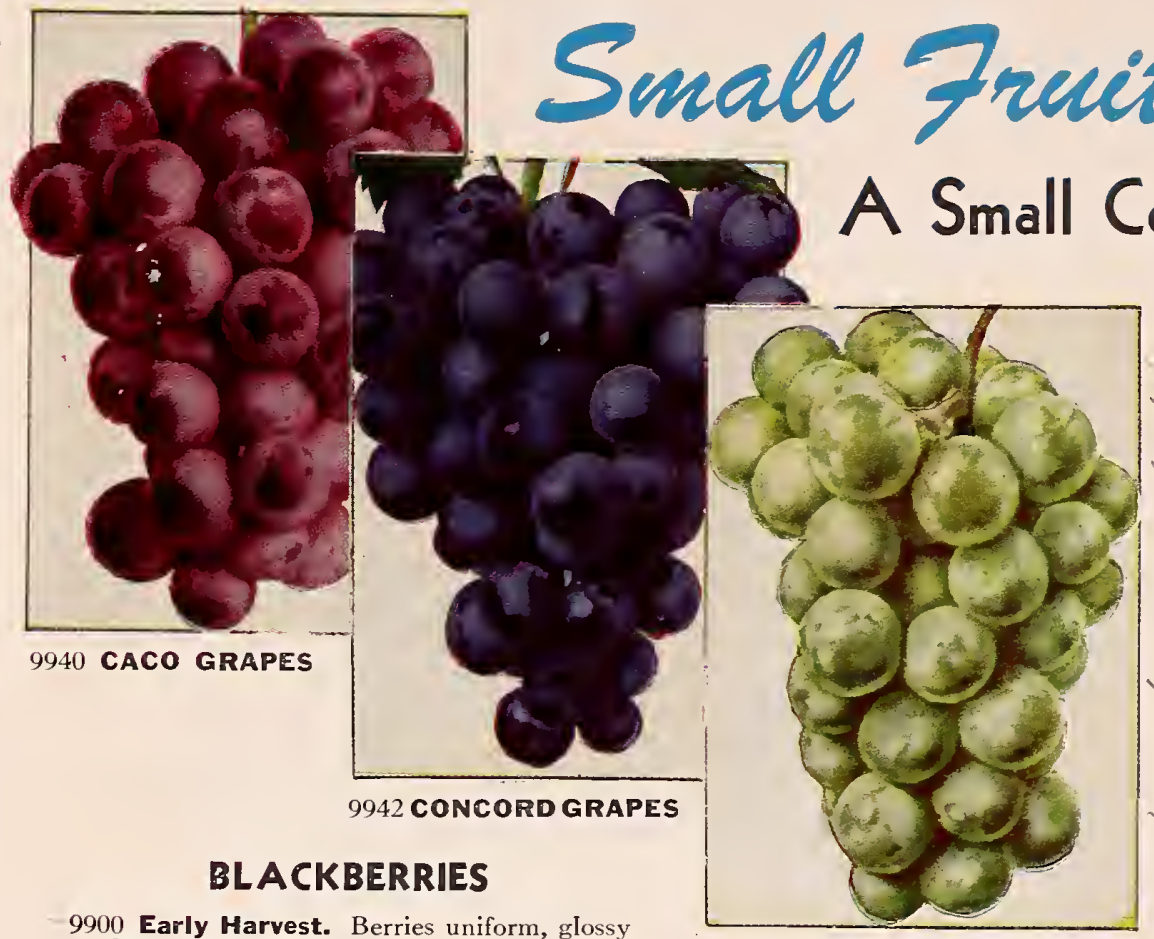

9900 Early Harvest. Berries uniform, glossy

black. Very early.

9906 Lucretia Dewberry. Fruit very Iarge;

9953 PORTLAND GRAPES

\title{
for Big Savings
}

\author{
GRAPES, European
}

9962 Flame Tokay. Large, sweet, red. 9964 Muscat. Large, light-colored raisin and wine Grape.

9966 Thompson Seedless. Popular table Grape.

All European Grapes, 1 to 9, 50c each; 10 to $29,37 \mathrm{c}$ each; 30 to $249,33 \mathrm{c}$ each All Grape-vines are 2-yr. No. 1 plants

\section{RED RASPBERRIES}

9970 Latham. This very desirable variety is certifred mosaic-free. Berries are large and round, with profitable shipping firmness and brilliant red color. 10 to $49,13 \mathrm{c}$ each 50 to $249,11 \mathrm{c}$ each; 250 to 1000 , 9c each. 9975 New Washington. Main-crop red Raspberry recently introduced by a Washington State experiment station. It is a strong, thrifty grower with unusual resistance to diseases. Ripening in midseason, the yield is heavy, the fruit long-capped, firm and somewhat better than average in both size and Aavor. New Washington requires well-drained soil; will not stand wet feet.

All Blackberries, 1 to $9,25 \mathrm{c}$ each; 10 to $29,20 \mathrm{c}$ each; 30 to $249,14 \mathrm{c}$ each; 250 to $1000,12 \mathrm{c}$ each

\section{BOYSENBERRIES}

9912 Thornless. Superior to all other vine berries in flavor, color, size and productiveness. 2-vr. transplants, 1 to $9,40 \mathrm{c}$ each; 10 to 29,35 c each; 30 to 249,28 c each; 250 to 1000 , $25 \mathrm{c}$ each.

\section{CURRANTS}

9923 Red Lake. Best quality and the most productive. The clusters are long and filled right out to the end with extralarge berries of bright glossy red. Delicious as a chilled dessert with cream and sugar and makes wonderful jelly. 1 to 9, $60 \mathrm{c}$ each; 10 to $29,50 \mathrm{c}$ each; 30 to $249,45 \mathrm{c}$ each.

\section{GOOSEBERRIES}

9930 Champion. Medium-sized red fruits. A gcod yielder. 1 to 9,75 c each; 10 to 29,65 c each; 30 to 249,60 c each; 250 to $1000,55 \mathrm{c} \mathrm{each}$.

9936 Poorman. A splendid Gooseberry with Iarge red fruits of highest quality. 1 to $9, \$ 1.00$ each; 10 to $29,90 \mathrm{c}$ each; 30 to $249,80 \mathrm{c}$ each; 250 to $1000,70 \mathrm{c}$ each.

\section{GRAPES, Hardy American}

9940 Caco. Hardy red Grape. Large, juicy and delicious. 1 to $9,50 \mathrm{c}$ each; 10 to $29,37 \mathrm{c}$ each; 30 to $249,33 \mathrm{c}$ each; 250 to $1000,30 \mathrm{c}$ each.

9942 Concord. Deep purple. Most popular for jelly or grape juice. 1 to $9,50 \mathrm{c}$ each; 10 to $29,35 \mathrm{c}$ each; 30 to $249,25 \mathrm{c}$ each; 250 to 1000,22 c each.

9948 Golden Muscat. Very large clusters and berries. The fruit is tender, sweet, juicy and aromatic. Ripens 10 days later than Concord.

9953 Portland. This new early white Grape has risen to first place in its class. Vigorous and productive. 1 to $9,50 \mathrm{c}$ each; 10 to $29,37 \mathrm{c}$ each; 30 to $249,33 \mathrm{c}$ each; 250 to $1000,30 \mathrm{c}$ each.

9956 Seneca. A green California-type Grape on a hardy vine. The firm, meaty flesh of superlative quality keeps well either on the vine or off. Ripens 3 weeks before Concord.

9958 Van Buren. Ripens a month earlier than Concord. The fruit is of the Concord type and equal to it in quality.

Any of above, except where noted, 1 to 9, $\$ 1.00$ each; 10 to $29,90 \mathrm{c}$ each
9974 Colossus. Several years of extensive planting have proved Colossus to be our finest everbearing red Raspberry. The fruits are very large and firm and do not crumble. Color and flavor are excellent. Highly recommended for canning, freezing or for eating fresh with cream and sugar. Extremely vigorous and hardy.

9976 Indian Summer. Another popular everbearing Raspberry. The fruits are Iarge, medium red and of top flavor. The vigorous plants bear heavy crops-the first soon after the June varieties and the second from September until frost.

All Red Raspberries, except Latham, 1 to 9, 25c each; 10 to 49,20 c each; 50 to $249,14 \mathrm{c}$ each; 250 to $1000,12 \mathrm{c}$ each

\section{BLACK AND PURPLE RASPBERRIES}

$\checkmark 9980$ Bristol (Black). The berries are large, firm, fairly glossy and of excellent quality.

$\neg 9984$ Sodus. (Purple.) Vigorous and very productive. Hardy drought-resistant plants that yield a good crop every year. The fruits are large, firm, medium purple in color.

Each of the above, 1 to $9,25 \mathrm{c}$ each; 10 to $49,20 \mathrm{c}$ each; 50 to 249 , $14 \mathrm{c}$ each; 250 to $1000,12 \mathrm{c}$ each

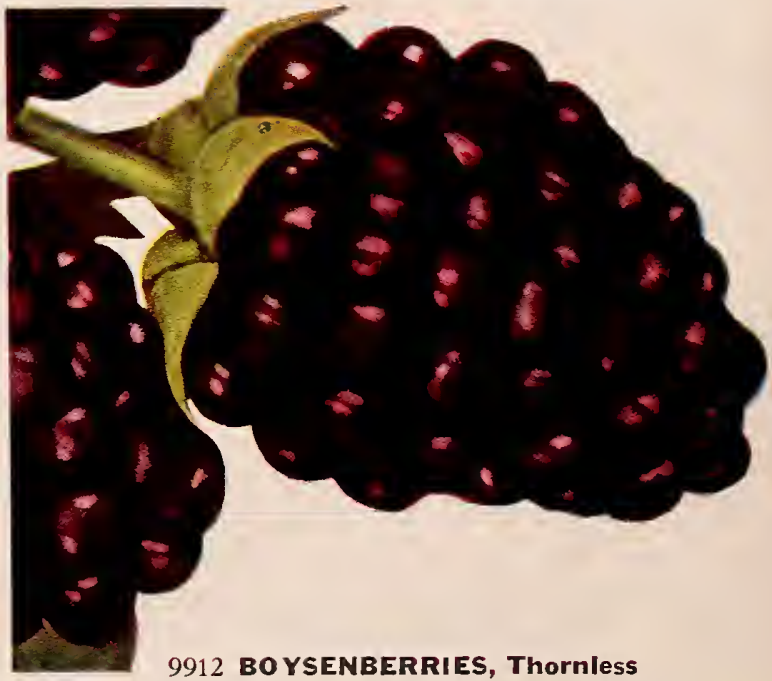




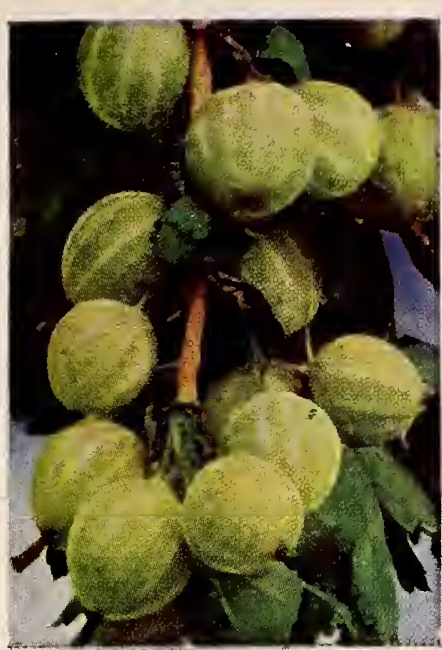

9936 GOOSEBERRIES,

Poorman

\section{STRAWBERRIES}

All Strawberry plants will be sent by either Parcel Post or Express, according to quantity. They are packed in bunches of 25 plants each.

9990 Marshail. The most extensively grown main-crop variety. The color is a rich, glistening crimson.

9989 Shasta. This new highyielding Strawberry is now being grown commercially in the Salt Lake Valley, where it has produced the largest crops of all varieties tried. In the main-
crop class, Shasta is preferred over the old favorite, Marshal! because of its extra vigor and productivity. The large fruit is tender, with medium firm flesh and mild subacid flavor. An exccllent market berry and has possibilities for shipping.

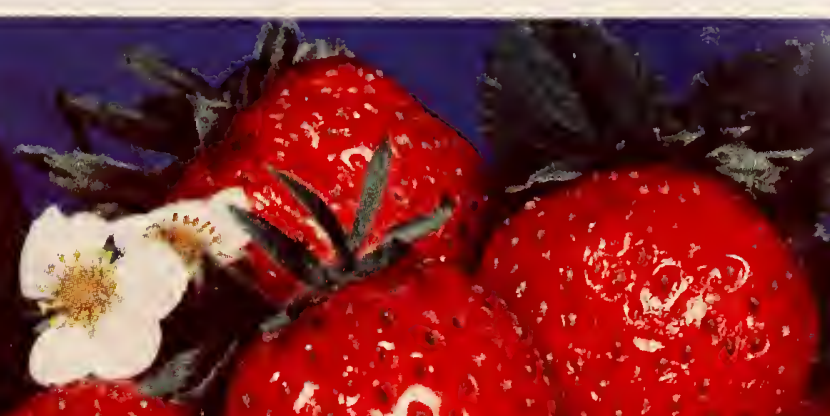

PRICES OF STRAWBERRIES

Strawberries are sold only in bunches of approximately 25 plants each.

\begin{tabular}{|c|c|c|c|c|}
\hline & \multicolumn{4}{|c|}{ Prices per plant } \\
\hline & $\begin{array}{c}25 \text { to } 50 \\
\text { each }\end{array}$ & $\begin{array}{l}75 \text { to } 225 \\
\text { each }\end{array}$ & $\begin{array}{c}250 \text { to } 975 \\
\text { each }\end{array}$ & $\begin{array}{l}1000 \text { up } \\
\text { each }\end{array}$ \\
\hline $\begin{array}{l}\text { Marshall } \ldots \ldots \ldots \ldots \ldots \ldots \ldots \\
\text { Shasta (New) } \\
\text { Utah Centennial } \ldots \ldots \ldots \ldots \ldots \ldots \ldots\end{array}$ & $\begin{array}{ll}\$ 0 & 04 \\
& 08 \\
& 08\end{array}$ & $\begin{array}{ll}\$ 0 & 03 \\
& 06 \\
& 06\end{array}$ & 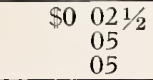 & $\begin{array}{ll}\$ 0 & 02 \\
& 04 \\
& 04\end{array}$ \\
\hline
\end{tabular}

MAIL ORDER INFORMATION

All prices are f.o.b. Salt Lake City. Send additional for packing and postage: 25c for

tah Centennial. The finest new everbearing Strawberry of the century. The giant, dark red berries have a distinctive flavor combining piquancy with sweetness. Amazingly productive. The fruits handle very wcll in marketing. up to 75 plamts; $40 \mathrm{c}$ for up tn 150 ; 80 c for up to 400 ; $\$ 1.30$ for 1000 plants.

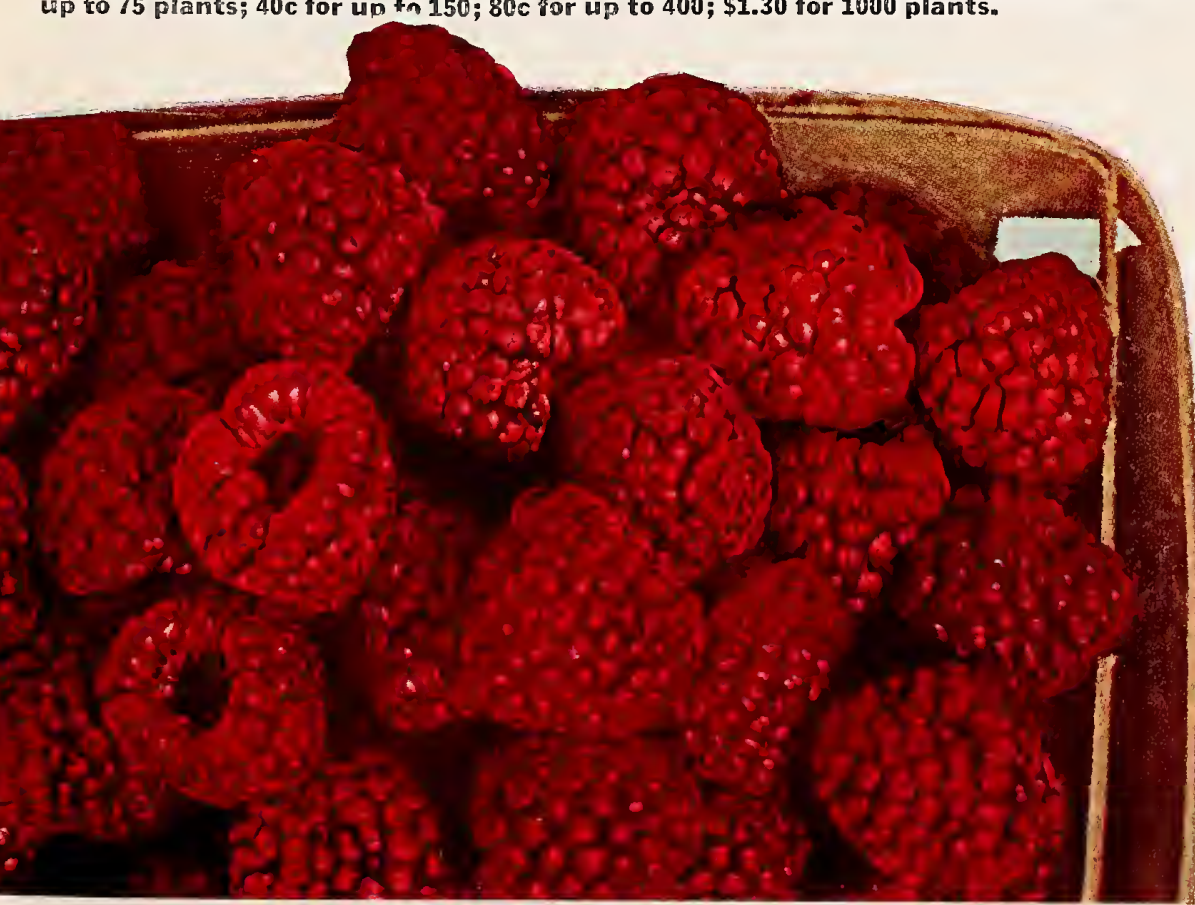

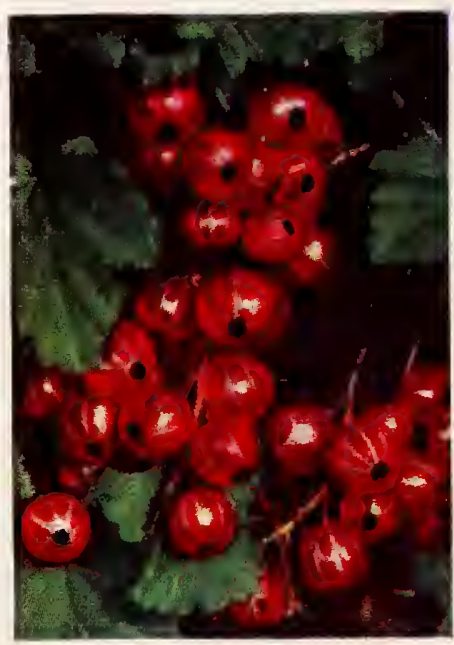

9923 CURRANTS, Fed Lake

MAIL ORDER INFORMATION

All stock is f.o.b. Salt Lake City. Send an additional amount for packing and postage.

\begin{tabular}{c|c|c}
\hline $\begin{array}{c}\text { Total } \\
\text { number of } \\
\text { plants } \\
\text { ordered }\end{array}$ & $\begin{array}{c}\text { For: } \\
\text { Grapes, } \\
\text { Currants, } \\
\text { Goose- } \\
\text { berries }\end{array}$ & $\begin{array}{c}\text { Rasp- } \\
\text { berries, } \\
\text { Boysen- } \\
\text { berries, } \\
\text { etc. }\end{array}$ \\
\hline 3 & $\$ 0.30$ &. \\
10 & .45 & $\$ 0.30$ \\
25 & .70 & .50 \\
50 & 1.10 & .85 \\
100 & $*$ & 1.20 \\
\hline
\end{tabular}

*Express or motor freight is recommended for larger quantities. 
